\title{
Role of endoplasmic reticulum stress in size-dependent inhibition of P-glycoprotein by silver nanoparticles in multidrug-resistant breast cancer cells
}

\author{
Ph.D. Thesis
}

Mohana Krishna Gopisetty

\author{
Supervisor \\ Dr. Mónika Kiricsi
}

Doctoral school of Biology

Department of Biochemistry and Molecular Biology

Faculty of Science and Informatics

University of Szeged

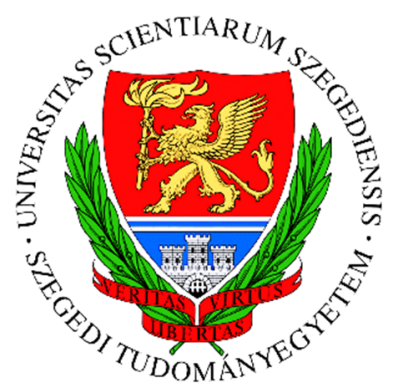

Szeged 2020 


\section{LIST OF CONTENTS}

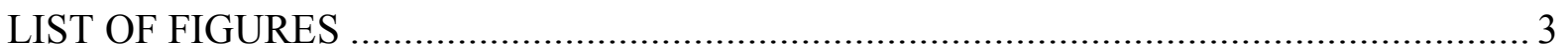

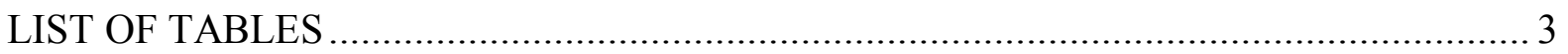

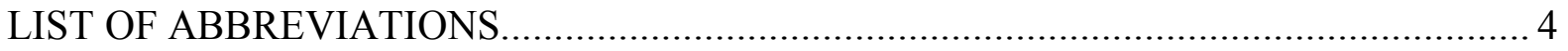

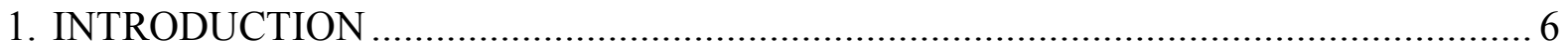

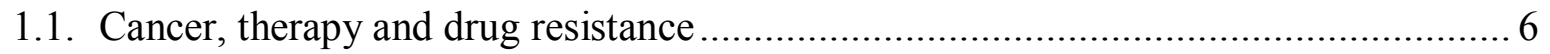

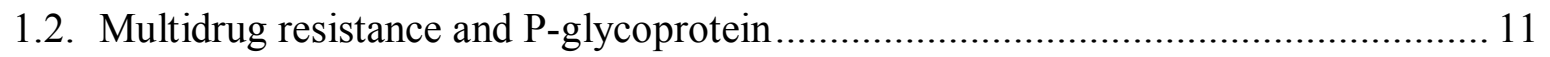

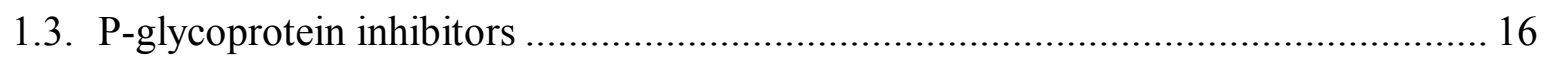

1.4. Alternate strategies to overcome Pgp mediated drug resistance ............................. 17

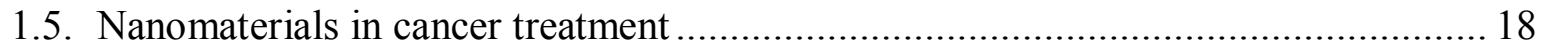

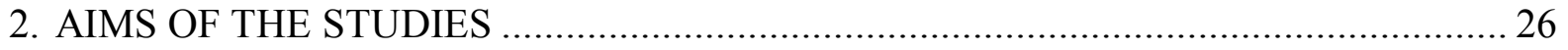

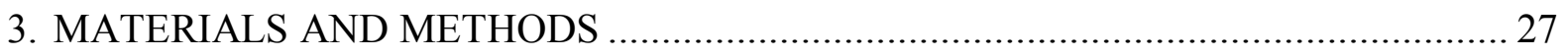

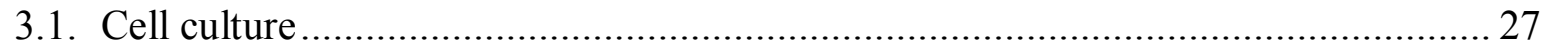

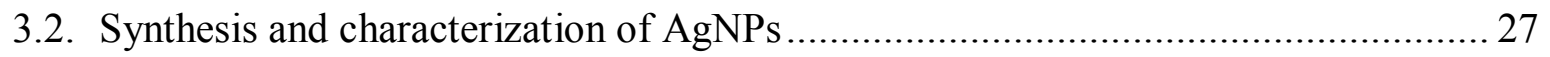

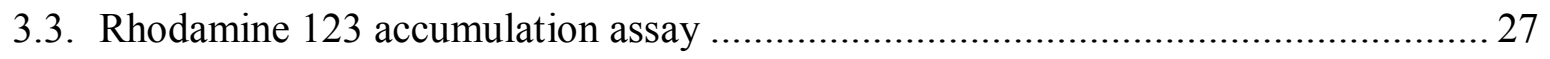

3.4. Preparation of plasma membrane and cytoplasmic fractions................................. 28

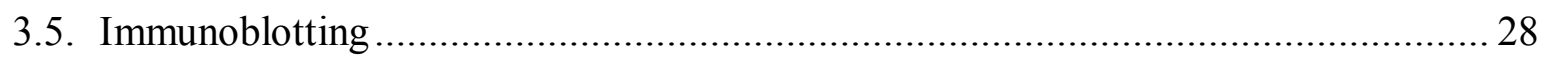

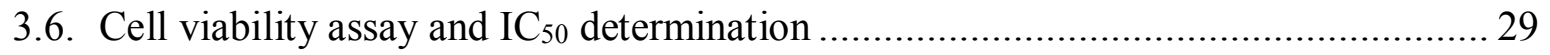

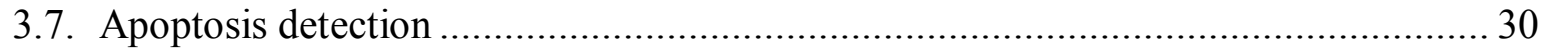

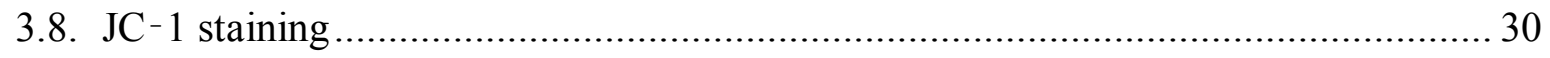

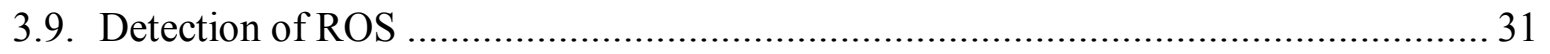

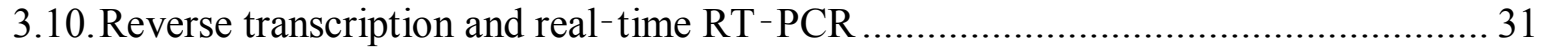

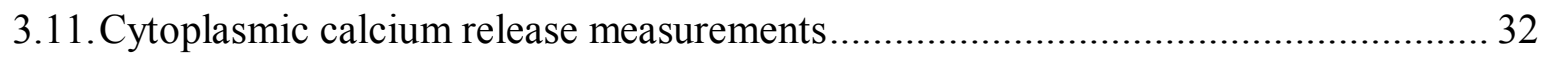

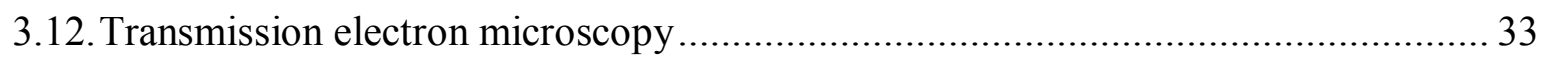

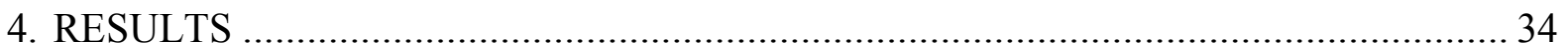

4.1. Characterization of the synthesized silver nanoparticles and the cell lines................ 34

4.2. Silver nanoparticles induce size-dependent cytotoxicity in breast cancer cells ......... 37

4.3. $75 \mathrm{~nm}$ AgNP treatment inhibits Pgp efflux activity but does not affect protein

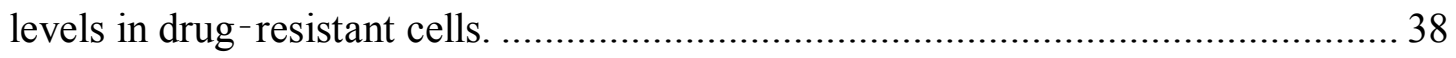

4.4. Inhibition of Pgp by $75 \mathrm{~nm}$ AgNPs sensitizes drug-resistant cells to doxorubicin-

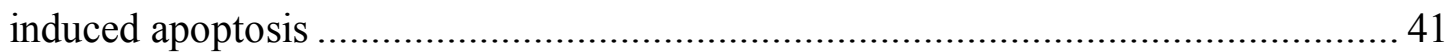

4.5. AgNPs induce oxidative stress and mitochondrial damage .................................. 43 
4.6. $75 \mathrm{~nm}$ AgNP treatments cause depletion of ER calcium stores and ER stress 46

4.7. $75 \mathrm{~nm}$ AgNPs disrupt cellular Pgp distribution 50

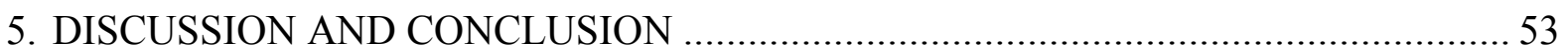

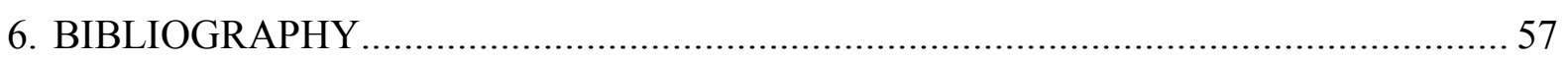

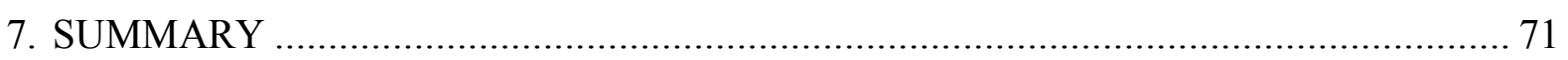

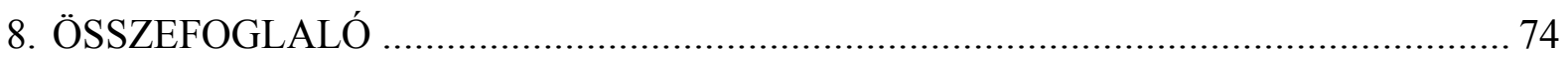

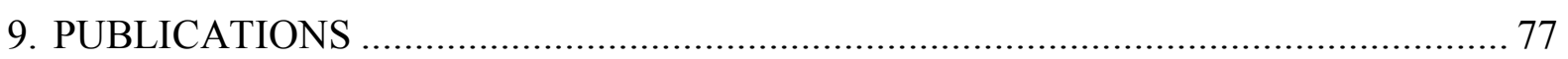

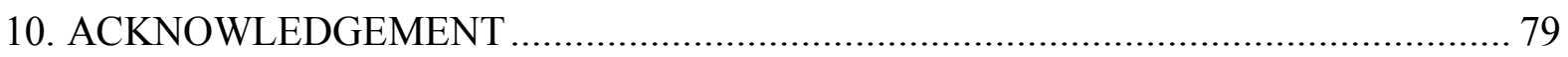




\section{LIST OF FIGURES}

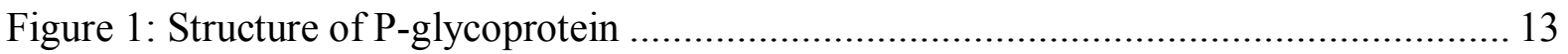

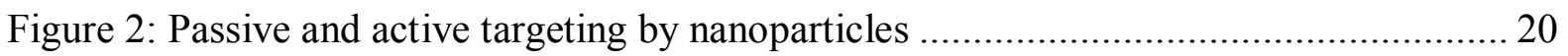

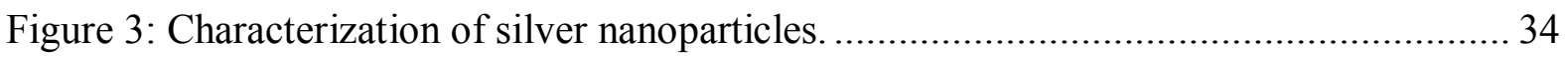

Figure 4: Hydrodynamic diameter and zeta potential of AgNPs ..................................... 35

Figure 5: Characterization of multidrug-resistant MCF-7/KCR cells ................................ 36

Figure 6: Rhodamine 123 efflux activity of drug-resistant MCF-7/KCR cells under AgNP

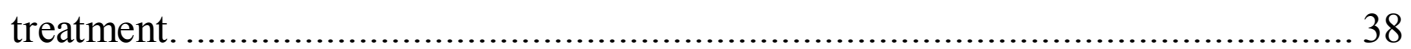

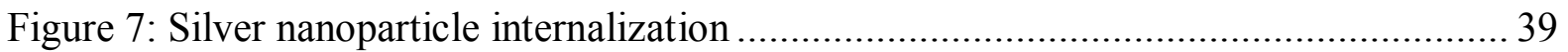

Figure 8: Pgp protein expression level in MCF-7/KCR cells after AgNP treatment............. 40

Figure 9: Sensitizing effect of $75 \mathrm{~nm}$ AgNPs to doxorubicin-induced cell death................. 41

Figure 10: AgNPs induce mitochondrial damage in MCF-7/KCR cells............................. 43

Figure 11: Cytoplasmic cytochrome c protein level in AgNP-treated MCF-7/KCR cells...... 44

Figure 12: AgNPs induce ROS generation in MCF-7/KCR cells ...................................... 45

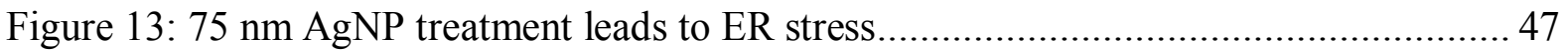

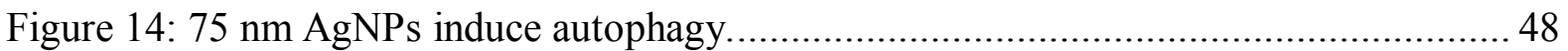

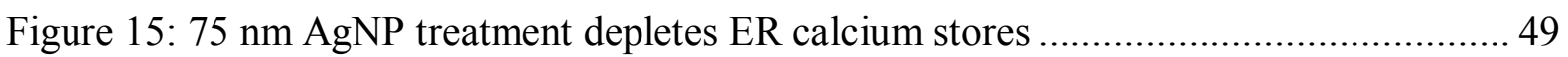

Figure 16: $75 \mathrm{~nm}$ AgNP treatment disrupts Pgp protein distribution between the plasma membrane and cytoplasm of MCF-7/KCR cells ........................................ 51

\section{LIST OF TABLES}

Table 1: Categories of chemotherapeutic drugs used in cancer treatment. .......................... 8

Table 2: General mechanisms of resistance to systemic therapy in cancers ....................... 11

Table 3: List of Pgp inhibitors used for clinical and non-clinical purposes..................17

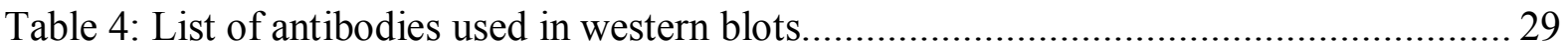

Table 5: List of sequence of primers used in quantitative real-time PCR ............................ 32

Table 6: Table of $\mathrm{IC}_{50}$ values calculated from MTT assay.............................. 37 


\section{LIST OF ABBREVIATIONS}

ABC: ATP binding cassettes

AgNPs: Silver nanoparticles

BCRP: Breast cancer resistance protein

CAM Kinase: $\mathrm{Ca}^{2+} /$ calmodulin-dependent protein kinase

DCFDA: 2',7'-dichlorofluorescein diacetate

DMSO: Dimethyl sulfoxide

DTT: Dithiothreitol

EDEM: ER degradation-enhancing $\alpha$-mannosidase- like protein

ER: Endoplasmic reticulum

ERAD: ER- associated protein degradation

FBS: Foetal bovine serum

FITC: Fluorescein isothiocyanate

GADD153: Growth arrest and DNA damage 153

GAPDH: Glyceraldehyde-3-phosphate dehydrogenase

Grp78: 78 kDa Glucose-regulated protein

Grp94: 94 kDa Glucose-regulated protein

HDAC: Histone deacetylase

JNK: Jun N-terminal kinase

LC3: Microtubule associated light chain 3 protein

MAPK: Microtubule associated protein kinase

MDR: Multidrug resistance

MRP: Multidrug resistance protein

MTT: 3-(4,5-dimethylthiazol-2-yl)-2,5-diphenyl tetrazolium bromide

NF-kB: Nuclear factor kappa-light-chain-enhancer of activated B cells

PBS: Phosphate buffered saline

PI3K: Phosphatidyl inositol-3-kinase

PIC: Protease inhibitory cocktail

PKC: Protein kinase C 
RH123: Rhodamine 123

ROI: Region of interest

ROS: Reactive oxygen species

SDS: Sodium dodecyl sulfate

UPR: Unfolded protein response 


\section{INTRODUCTION}

\subsection{Cancer, therapy and drug resistance}

Cells randomly lose regulation over their growth limiting mechanisms, grow uncontrollably into a mass of cells, generally called cancer. The term cancer (Greek for crab) was coined between 460-370 BC by the Greek physician Hippocrates to describe nonulcer and ulcer forming tumours, which had finger like projections resembling the shape of a crab. The era before Hippocrates was also not free from cancer, which is substantiated by fossil records of early humans in ancient Egypt and Greece (David et al., 2010) and by "Edwin smith papyrus" from $1600 \mathrm{BC}$, the earliest authentic description of cancer.

Technological advancement and development of procedures to comprehend biology to the level of molecular structures and mechanisms had enabled cell biologists to understand cellular growth, replication and their regulation. The cell is a highly organized functional unit, which represents the fundamental component of all living organisms. Cell birth and death ensure development and involve complexly regulated molecular mechanisms, which are in precise balance to maintain the normal turnover of cells and tissue specific functions. Therefore, aberrations in those mechanisms and their regulating factors would lead to deregulated apoptosis or uncontrolled proliferation of cells, hence to pathological conditions like tissue degenerative diseases and cancers.

Cell proliferation is a definitive term for cell duplication, where a completely functional cell originates from an existing cell through a process called cell cycle. Cell cycle encompasses four distinct phases called G1, S, G2 and M. G1 and G2 are preparatory phases, in the synthesis phase (S) the duplication of cellular genome occurs and M stands for either mitosis or meiosis. Based on differential DNA content requirements (haploid or diploid) of germ and somatic cells, meiosis and mitosis are different processes respectively, where meiosis is designed to halve the DNA content in daughter cells.

In various cellular situations like senescence, infection, irreparable DNA damage and stress, cells must undergo death in order to strand aberrations and preserve the normal physiological functions of the tissues. One of the most studied cell death pathways, that follows a particular programme involving biochemical events as well as morphological alterations, is apoptosis. Orchestrated by energy-dependent cascade of molecular events, apoptosis is a complex and sophisticated mechanism that works to eliminate cells from the 
system. Apoptosis is activated by a plethora of extrinsic and intrinsic signals. The majority of them signal to release cytochrome c (cyt c) from the mitochondria into the cytoplasm. Cyt $\mathrm{c}$ interacts with apoptotic protease activating factor (Apaf) to activate caspases, which are the key components in ensuring apoptotic cell death. Apoptotic cells compared to nonapoptotic cells show various demarcating morphological and biochemical features like plasma membrane blebbing, cell budding, nuclear fragmentation, mitochondrial damage and flipping out plasma membrane phosphatidylserine (Van Cruchten et al., 2002). These demarcating features serve the basis for several experimental techniques to detect apoptotic cells from non-apoptotic cells.

Cancer is defined as aberrant over-proliferation of cells. Cells from almost every part of the body have a propensity for turning cancerous due to altered genes and deregulated molecular mechanisms. Based on their origin cancers are broadly classified as carcinomas, sarcomas, leukemias and lymphomas. Benign tumours pose little risk to the host and are mostly confined to the tissue of their origin whereas, malignant tumours pose immoderate risk due to their rapid proliferative capacity and tendency to metastasize (migration to other parts from their primary origin) (Sinha 2018). Cellular mechanisms including proliferation and apoptosis are ultimately instructed by a number of genes and their expression pattern. Therefore, genetic mutations are capable to distort these precisely regulated mechanisms and cause cancers. Oncogenes are genes that can drive cancer development as they encode proteins able to transform cells and induce cancer. Cellular genes known to be progenitors of oncogenes are called proto-oncogenes. These are important for normal cellular processes, are often involved in signal transduction and execution of mitogenic signals, but they can be altered to become oncogenes upon acquiring an activating mutation (Lodish et al., 1064). Growth promoting genes encode anti-apoptotic proteins, transcription factors, growth factor receptors and components of proliferative signalling pathways. Gain-offunction mutations in these genes over-stimulate cellular proliferation and therefore can generate cancer. On the other hand, tumor suppressor genes encode components of proapoptotic signalling pathways, negative regulators of cell cycle progression and checkpoint-control proteins assessing DNA damage (Lee et al., 2010). Loss-of-function mutations in these genes breaks their negative regulation over cell proliferation and survival, which ultimately leads to cancer.

Removal of cancerous outgrowth is an important goal in cancer management. Surgery can be the first line of cancer therapy and can be curative for early stage cancers. In 
localised setting and in conjunction with surgery, radiotherapy is also often used. Surgery and radiation, although proved to be effective cancer therapeutics their preference is restricted mostly to non-metastatic cancers. Other conventional and modern types of cancer therapy comprise chemotherapy, immunotherapy, targeted therapy, hormone therapy, stem cell therapy and personalized medicine (Schirrmacher 2019). Chemotherapy involves the application of cytotoxic drugs to kill cancer cells and is the preferred line of cancer management owing to their proved effectiveness as an adjuvant therapy and in the treatment of overtly disseminated cancers. As an example, doxorubicin is used in the chemotherapeutic management of several different cancers such as carcinomas of the breast, endometrium, ovary, testicles, thyroid and the lungs, or in some sarcomas, as well as in hematologic cancers. Doxorubicin is an anthracycline line drug that exhibits a highaffinity binding to DNA, inhibits Topoisomerase II by intercalating the DNA, blocks the synthesis of DNA and RNA, causes DNA strand scission thereby leading to the inhibition of cell proliferation and ultimately to apoptosis. Besides this effect, doxorubicin induces the generation of ROS which is probably the main cause of its cardiac toxicity through ROS-mediated damage to membranes.

Based on their target cellular function, chemotherapeutic drugs are broadly classified into anti-metabolites, genotoxic agents and mitotic spindle inhibitors. Anti-metabolites interfere with nucleic acid metabolism and limit the available nucleotides for DNA replication whereas, genotoxic agents induce DNA damage. Therefore, both antimetabolites and genotoxic agents have direct effects on DNA replication during the S-phase of the cell cycle. On the other hand, mitotic spindle inhibitors interfere with microtubule dynamics and inhibit segregation of chromosomes during cell division. Application of these drugs would eventually induce cellular apoptosis leading to cell death. Table 1. summarizes commonly used chemotherapeutic drugs and their general molecular targets.

Table 1: Categories of chemotherapeutic drugs used in cancer treatment

Category

Drugs

\section{Alkylating Agents}

Mustard gas derivatives

mechlorethamine, cyclophosphamide, chlorambucil, melphalan, bendamustine,

Ethylenimines

Alkylsulfonates uramustine, chlormethine and ifosfamide. thiotepa and hexamethylmelamine busulfan 
Hydrazines and Triazines

Nitrosureas

Metal salts

\section{Anthracyclines}

\section{Cytoskeletal disruptors}

Taxanes

Epothilones

Enzyme inhibitors

HDAC inhibitors

Topoisomerase I inhibitors

Topoisomerase II inhibitors

Kinase inhibitors

\section{Nucleotide and Folate analogs}

\section{Peptide antibiotics}

Platinum drugs

\section{Retinoids}

Vinca alkaloids and derivatives

\section{Hormonal drugs}

Aromatase inhibitors

Androgen synthesis/receptor modulators altretamine, procarbazine, dacarbazine and temozolomide

carmustine, lomustine and streptozocin

carboplatin, cisplatin, and oxaliplatin

daunorubicin, doxorubicin, epirubicin, idarubicin, mitoxantrone and valrubicin

paclitaxel, docetaxel, abraxane and taxotere

patupilone and ixabepilone

vorinostat and romidepsin

irinotecan and topotecan

etoposide, teniposide and tafluposide

bortezomib, irlotinib, gefitinib, imatinib, vemurafenib and vismodegib azacitidine, azathioprine, capecitabine, cytarabine, fludarabine, cladribine, doxifluridine, fluorouracil, gemcitabine, hydroxyurea, mercaptopurine, methotrexate, raltitrexed, pemetraxed, lometrexol, nolatrexed, trimethoprim, pralatrexate and piritrexim

bleomycin and actinomycin carboplatin, cisplatin, dicycloplatin, eptaplatin, lobaplatin, miriplatin, nedaplatin, picoplatin, satraplatin, triplatin tetranitrate and oxaliplatin

tretinoin, alitretinoin, isotretinoin and bexarotene

vinblastine, vincristine, vindesine, vincaminol, vineridine, vinburnine and vinorelbine

aminoglutethimide, testolactone, anastrozole, letrozole, exemestane, vorozole, formestane and fadrozole cyproterone acetate, flutamide, nilutamide, bicalutamide, enzalutamide, abiraterone acetate, seviteronel, apalutamide and darolutamide 
Estrogen synthesis/receptor

modulators

\section{Proteasome Inhibitors}

ethamoxytriphetol, tamoxifen, clomifene and raloxifene

bortezomib, ixazomib, boronate

ixazomib, epoxyketone oprozomib, $\beta$ -

lactone marizomib, boronate delanzomib

and carfilzomib

Adapted from (Chemotherapeutic Agents - Knowledge for Medical Students and Physicians, www.amboss.com)

Similar to antibiotic resistance in bacterial cells, cancer cells also attain resistance to a number of chemotherapeutic drugs. In many cases, cancers initially responsive to a specific drug or combination of drugs fail to respond later on. Drug resistance in cancer cells can be both inherent and acquired. Inherent resistance appears in cancer cells, which evolved randomly to resist drugs under no selection pressure. Tumors consisting of more than $10^{6}$ cells likely contain at least 1 such cell that is resistant to a specific drug (Luqmani 2005) and survives the systemic therapy, eventually causing cancer relapse (Biedler et al., 1970). Cancer cells are able to acquire resistance following repeated exposure to drugs. The basis of acquired resistance lays on drug-induced mutations and other adaptive responses (Holohan et al., 2013). Most of the chemotherapeutic drugs induce oxidative stress (Conklin 2004), which potentially trigger genetic mutations. These genetic mutations tend to accumulate in neoplastic cells and some of these accumulated mutations in drug targets consequentially contribute to the development of drug resistance in cancer cells. Overexpression of transmembrane drug efflux pumps such as ABC transporters is a wellknown mechanism of drug resistance, where several chemotherapeutic drugs are expelled out from the cytoplasm. This phenomenon reduces the drugs' availability to elicit cytotoxicity. Several chemotherapeutic drugs exert their cytotoxicity by binding and inhibiting key proteins associated with cancer development. Therefore, altering the targets of a given drug is another key resistance mechanism in cancer cells. BCR-ABL kinase is associated with the pathogenesis of chronic myelogenous leukaemia (CML). Therapeutic application of the BCR-ABL kinase inhibitor Imatinib mesylate led to resistance attained by mutations in the drug binding site of the enzyme's kinase domain (Pan, 2012). In addition to inherent and acquired drug resistance, tumor microenvironment is also reported to orchestrate drug resistance in cancers (Senthebane et al. 2017). Please refer to Table 2. where various cellular mechanisms commonly associated with drug resistance in cancers are comprehensively presented. 
Table 2: General mechanisms of resistance to systemic therapy in cancers

\begin{tabular}{|c|c|}
\hline $\begin{array}{l}\text { Cellular and } \\
\text { biochemical } \\
\text { mechanisms }\end{array}$ & $\begin{array}{l}\text { Decreased drug accumulation } \\
\text { 1. Decreased drug influx } \\
\text { 2. Increased drug efflux } \\
\text { 3. Altered cellular drug trafficking } \\
\text { Increased activation of drug or toxic intermediate } \\
\text { Increased repair of or tolerance to drug-induced damage to } \\
\text { 1. DNA } \\
\text { 2. Protein } \\
\text { 3. Membranes } \\
\text { Decreased drug activation } \\
\text { Altered drug targets } \\
\text { Altered co-factor or metabolite levels } \\
\text { Altered downstream effectors of cytotoxicity } \\
\text { Altered signalling pathway and/or apoptosis in response to drug } \\
\text { 1. Altered gene expression } \\
\text { 2. DNA mutation, amplification or deletion } \\
\text { 3. Altered transcription or translation } \\
\text { 4. Altered post transcriptional processing } \\
\text { 5. Altered stability of macromolecules }\end{array}$ \\
\hline In vivo mechanisms & $\begin{array}{l}\text { Pharmacological and anatomic drug barriers } \\
\text { Host drug interactions } \\
\text { 1. Increased drug inactivation by normal tissue } \\
\text { 2. Decreased drug activation by normal tissue } \\
\text { 3. Relatively increased normal tissue drug sensitivity }\end{array}$ \\
\hline
\end{tabular}

Adapted from (Gonzalez-Angulo et al., 2007)

\subsection{Multidrug resistance and P-glycoprotein}

Cancers often develop drug resistance. This is one of the major obstacles in cancer chemotherapy both in neoadjuvant and adjuvant settings. Although, single compound resistance is relatively easier to deal with, cancers often acquire resistance not only to one particular drug but also to other structurally and functionally dissimilar drugs and the resulting multidrug resistance (MDR) is mostly hard to conquer. Studies of Biedler and Riehm on cultured cells exposed to Actinomycin D showed cross resistance to a wide array 
of structurally unrelated compounds like vinca alkaloids, puromycin, daunomycin and mitomycin C (Biedler et al., 1970). Later the cross resistance was attributed to a glycoprotein called permeability glycoprotein (P-glycoprotein; Pgp). Pgp is a member of the $\mathrm{ABC}$ family of efflux pumps and is involved in the energy dependent efflux of various, often structurally unrelated compounds. Overexpression of Pgp has been observed in a number of MDR cancers, therefore, Pgp overexpression represents a classic mechanism of multidrug resistance. In the last decade other MDR-related efflux proteins have been studied, such as the MRP family members including MRP1, MRP2 and MRP3 (Choi et al., 1988; Riordan et al., 1985; Zhan et al., 1997). The list of drug efflux transporters that grant MDR to cancers was further extended, since it was found that overexpression of breast cancer resistance protein (BCRP) in methotrexate overexposed MCF7 cells was involved in the development of cross resistance (Volk et al. 2000).

Pgp is a $170 \mathrm{kDa} \mathrm{N}$-glycosylated transmembrane protein that binds and transports several drugs and molecules out of the cytoplasm and is evolutionarily conserved (van Veen et al. 1998). Pgp efflux is fuelled by ATP hydrolysis, catalysed by one of its structural motifs called ATP Binding Cassette (thus Pgp is classified as an ABC transporter). Nevertheless, other transporters which do not belong to the ABC super family are also fuelled by ATP. Physiologically, Pgp is located on the apical membrane of gut epithelia, liver cells, kidney tubules and blood tissue barriers where its major function is to protect those cells from unwanted cytotoxic molecules thereby maintaining cellular integrity (Cordon-Cardo et al. 1990). Pgp is also expressed in adrenal glands, hematopoietic stem cells, natural killer cells, antigen presenting dendritic cells and T and B lymphocytes, even though Pgp downregulation in those cells did not affect the immune system in general (Schinkel et al. 1997). Other than these, Pgp is also involved in regulating volume activated chloride channels (Valverde et al. 1992), phospholipid translocation (Ruetz 1994), cholesterol metabolism (Luker et al., 1999), differentiation (Williams, 1993) and cell death (Traycoff et al. 1998) 


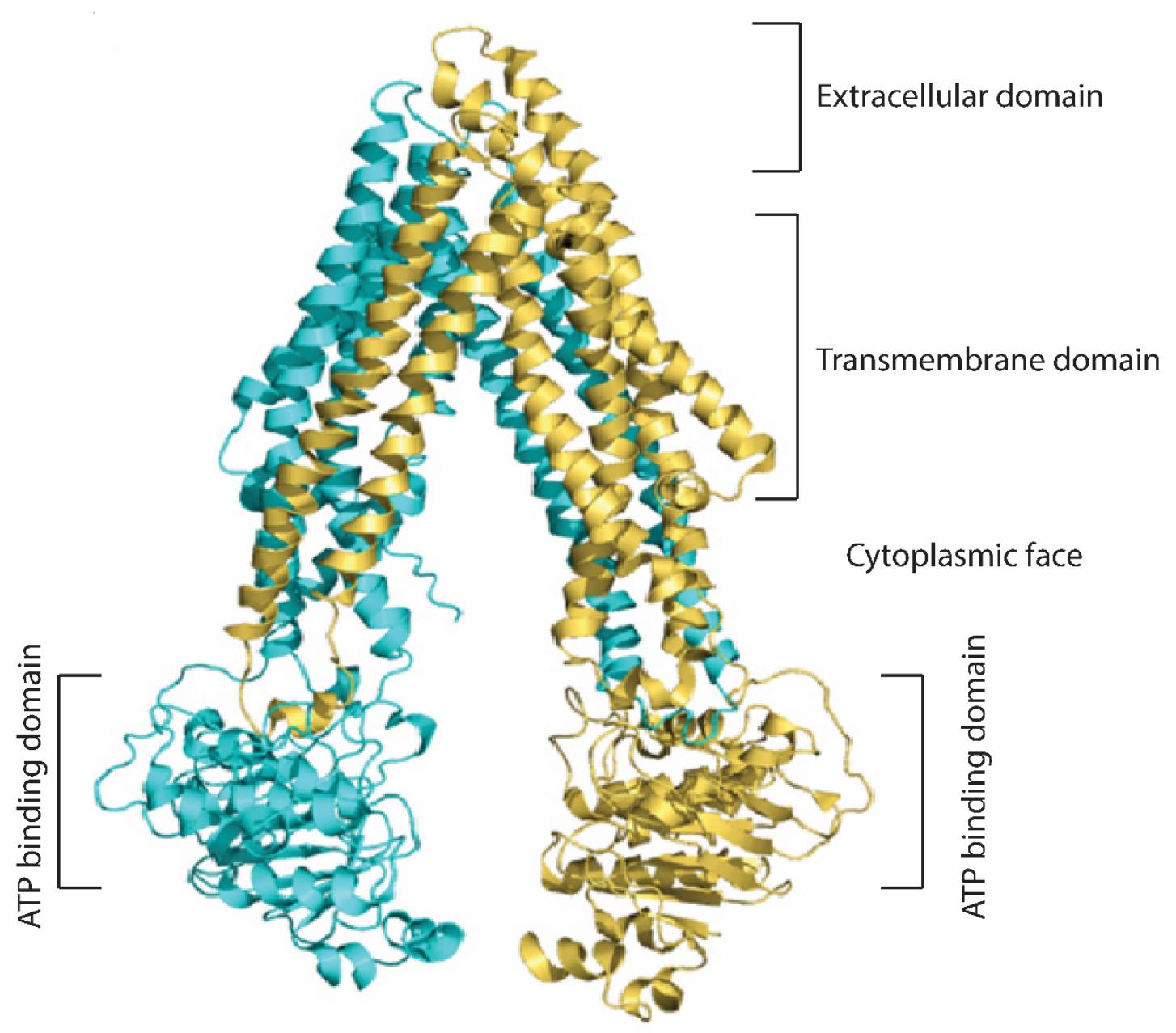

Figure 1: Structure of P-glycoprotein (Sharom 2014)

As it is shown in Figure 1. Pgp comprises of an extracellular domain, transmembrane domains and cytoplasmic domains. The extracellular domain contains 3-4 conserved Nglycosylation sites whereas, on the cytoplasmic side it has two hydrophilic nucleotide binding domains (NBDs) that bind and hydrolyse ATP. Pgp contains two hydrophobic transmembrane domains and each domain passes the membrane 6-times through putative $\alpha$-helices. Since Pgp is a transmembrane transporter, it is widely believed that its substrates bind to Pgp on the cytosolic side and are released to the outside following Pgp's conformational change powered by ATP hydrolysis. Analogously, this mechanism often referred to as the "Hydrophobic vacuum cleaner" model (Gottesman et al., 1993). This model explains multidrug resistance mainly by the efflux of drugs, which had already entered the cell. However, Pgp's efflux function is also explained by another widely accepted model called the "flippase" model, which ascertains that Pgp intercepts the drug movement through the plasma membrane and releases the drug outside by the transporter's 
flippase activity (Higgins et al., 1992). This model explains multidrug resistance mainly by inhibiting the entry of drugs to the cytoplasm. Although there are other models to describe Pgp efflux activity, the "Hydrophobic vacuum cleaner" and "flippase" models are the most accepted due to their applicability to other ABC transporters (Kamp et al., 1998; van Helvoort et al., 1996). Since Pgp overexpression confers resistance by both reducing the influx and increasing the efflux of drugs it is possible that these mechanisms work in cooperation to protect cells from jeopardizing drugs. Besides the plasma membrane, Pgp overexpression and enhanced function could be identified in intracellular organelles, which might also contribute to drug resistance. It has been reported that lysosomal membrane localization of Pgp provides multidrug resistance majorly by drug sequestration (Yamagishi et al. 2013). Moreover, Molinari et al. proved that due to Pgp expression in the Golgi apparatus of human melanoma cells doxorubicin was sequestered in the Golgi (Molinari et al. 1998) despite the fact that no changes in drug sensitivity of human melanoma cells were observed.

In cancer cells Pgp overexpression is mostly mediated by altered transcription induced by altered growth regulating signal transduction pathways. A redundant number of signalling pathways are involved in the regulation of Pgp/MDR1 expression encompassing MAP kinase, JNK, p38, CAM kinase, PI3K and PKC. Sui et al. has reviewed all these pathways with a special focus on their role in MDR1 regulation (Sui et al., 2012). Pgp/MDR1 overexpression has been the result of both prolonged (Kohno et al. 1994) and short-term (Chaudhary et al., 1991) exposures to cytotoxic drugs. Chaudary et al. have also reported that Pgp overexpression is not just associated with short or long-term exposure to any of the Pgp substrate drugs, but also to other cellular stress inducing drugs, which are not substrates of Pgp (Chaudhary et al., 1991). Since the most important physiological role of Pgp is to protect cells from xenobiotics and lethal drugs, hence it is rational to expect that cellular stress is a potent inducer of Pgp expression. In fact, cellular stress has a direct effect on Pgp/MDR1 gene expression since, MDR1 gene contains in its promoter Heatshock elements (HSEs) where heat-shock factors (HSFs) can bind. It was reported by Vilaboa et al., that HSF1 positively regulates MDR1 gene activity during heat-shock and arsenic exposure in HeLa cells (Vilaboa et al., 2000). The contrary, inhibition of endogenous HSF1 had been reported to induce NF-kB binding to MDR1 which leads to its expression in breast cancer cells (Kanagasabai et al., 2011). These authors also revealed that inhibition of HSF1 induces gain-of-function mutations in p53, which in turn triggered 
MDR1 expression again through NF-kB binding (Kanagasabai et al. 2011). This strongly indicates that HSF1 has both direct and indirect roles in modulating MDR1 expression. Additionally, loss-of-function mutations in p53 can induce MDR1 expression (Thottassery et al., 1997). Since, p53 is a prominent tumour suppressor and its loss has been connected to most cancers, it is important to realize that the loss of p53 causes cancer drug resistance in two possible ways i, by compromising the cellular apoptotic machinery, ii, by inducing MDR1 expression. As an example, a unique post-transcriptional regulation mechanism via the 5 ' untranslated fragment of the MDR1 mRNA was reported by Mata Balaguer and colleagues (Mata Balaguer et al. 2012), where it was shown that HDAC inhibitors regulate Pgp expression from two alternative promoters, where transcription from one promoter produces translatable mRNA with long 5'UTR, whereas transcription from alternate promoter produces non-translatable mRNA with short 5 'UTR.

MicroRNAs (miRNAs) are small non-coding RNAs transcribed both from exons and introns of the coding genes (Rutnam et al., 2013), which are involved in the posttranscriptional regulation of gene expression by targeting mRNA molecules. Numerous reports have suggested that miRNAs play a key role in regulating multidrug resistance, including Pgp/MDR1 expression, in cancers (also reviewed by Xin An and his colleagues: An et al., 2017). Kovalchuk et al. published a study about the downregulation of Pgp expression by miR-45 in multidrug-resistant MCF-7 breast cancer cells (Kovalchuk et al. 2008). Similarly, miR-298 regulated negatively Pgp expression in metastatic breast cancer cells (Bao et al. 2012) and low concentrations of small interfering RNAs have been observed to modulate MDR gene expression (Stierlé et al., 2005) in MCF-7 cells. Several other miRNAs such as miR-451, miR-27a, miR-508-5p, miR-331-5p and miR-154 were proposed to be directly implicated and others such as miR-137, miR-200c, miR-122, miR138, miR-19a/b and miR-130a indirectly involved in the regulation of MDR1 (Katayama et al., 2014).

Finally, since epigenetics can also play a great role in regulating gene expression pattern, the involvement of epigenetic regulation of MDR 1 expression cannot be omitted. In fact, there are several reports demonstrating the epigenetic control of MDR1 expression and as a consequence its association with drug resistance (Henrique et al., 2013; Mata Balaguer et al., 2012; Tomiyasu et al., 2014; Toth et al., 2012). 


\subsection{P-glycoprotein inhibitors}

Intervening Pgp efflux activity or expression is a promising strategy to improve intracellular chemotherapeutic drug accumulation and cytotoxicity. Despite pharmacological advances in this area several natural and synthetic Pgp inhibitors have not yet overcame the barriers of cancer cell specificity and off-target impacts.

\subsubsection{First-generation inhibitors}

In 1987, two years after comprehending the link between cancer cell drug resistance and Pgp expression (Gupta 1985), verapamil, a calcium channel blocker was shown to have Pgp inhibitory potential as a secondary target (Cano-Gauci et al., 1987). Verapamil competitively inhibits Pgp and represents a first-generation Pgp modulator. However, one of the major obstacles in the clinical application of verapamil is the fact that it needs to be administered in micromolar concentration to inhibit Pgp, whereas, it inhibits calcium channels in picomolar concentrations. Observed cardiac toxicities over verapamil administration overthrew the consideration of this drug as Pgp inhibitor in clinical settings (Ozols et al. 1987). Trifluoperazine, a calmodulin antagonist, cyclosporine, an immunosuppressant and other antihypertensives such as quinidine and reserpine, yohimbine, antiestrogenic tamoxifen and toremifene, and antineoplastic vincristine all belong to first-generation MDR modulators, which were ultimately suspended as clinically utilized MDR inhibitors on similar grounds as verapamil.

\subsubsection{Second-generation inhibitors}

The second generation comprises mainly first-generation drugs modified to diminish their off-target effects. Dexverapamil, valspodar, and other drugs were placed in this category. These drugs unfortunately also failed to be better contenders, as their chiral optimization rendered them to become substrates of cytochrome P450 (CYP4503A4) (Darby et al., 2011). Hence, their concurrent administration with chemotherapeutic drugs disturbed metabolic mechanisms and interfered with the pharmacological properties and clearance of the therapeutic drug (Darby et al., 2011).

\subsubsection{Third-generation inhibitors}

Tariquidar and other third-generation drugs were frequently associated with adverse drug reactions due to overlapping affinity of Pgp and CYP4503 A4 (Yu 1999). However, more recent studies have demonstrated that the co-administration of tariquidar with 
vinorelbine (Abraham et al. 2009) did not produce a similar toxicity profile in patients undertaking chemotherapy with Pgp substrate drugs doxorubicin/docetaxel (Pusztai et al. 2005). Moreover, a structure-activity investigation has produced derivatives of tariquidar with nearby negligible ability to interact with CYP4503A4, while retaining Pgp inhibition (Labrie et al. 2007).

Although significant scientific efforts focused on the development of Pgp inhibitors, most of them were dismissed on the grounds of safety, efficacy and disappointing performance in clinical trials (Chung et al. 2016). Table 3 provides a non-exhaustive list of non-clinical and clinical Pgp inhibitors.

Table 3: List of Pgp inhibitors used for clinical and non-clinical purposes

Category Inhibitors

Non-clinical

cyclosporin, elacridar, ketoconazole, quinidine, reserpine, ritonavir, tacrolimus, valspodar, verapamil and zosuquidar

Clinical amiodarone, carvedilol, clarithromycin, dronedarone, itraconazole, lapatinib, lopinavir, propafenone, quinidine, ranolazine, ritonavir, saquinavir, telaprevir, tipranavir and verapamil

\subsection{Alternate strategies to overcome Pgp mediated drug resistance}

Since achieving a sufficient intracellular concentration of the therapeutic drug is the major issue with Pgp-related MDR cancer cells, alternate methods that deliver drugs to cancer cells bypassing Pgp recognition proved to be a promising approach. Nanocarriers or nanoparticles such as liposomes, polymers, colloidal gold, and nanocrystals represent modern drug delivery systems by virtue of their capacity to bind drugs through adsorption, internalization, conjugation and chelation (McNeil, 2009; Milane et al., 2011). They offer a flexible platform owing to their high surface-to-volume ratio and ability to carry different payloads like drugs, DNA and RNA. For instance, siRNA loaded dextran nanocarriers demonstrated to decrease by 100 -fold the $\mathrm{IC}_{50}$ concentration of doxorubicin in Pgp overexpressing osteosarcoma cells (Susa et al. 2010). Doxorubicin encapsulated in liposomes showed a high degree of intracellular accumulation and thus a great capacity to evade Pgp (Sadasivan et al., 1991; Thierry et al., 2017). Another study revealed a successful treatment option using payload strategy (paclitaxel and lonidamine) to circumvent multidrug-resistance (Milane, Duan, and Amiji 2011). Superhigh-magnetization 
nanocarriers produced with a highly magnetic $\mathrm{Fe}_{3} \mathrm{O}_{4}$ core and a poly-[N-(1-butyric acid)]aniline shell have also been used to tackle Pgp-mediated MDR (Hua et al. 2011). A recent study had evaluated a copolymer of polystyrene oxide-polyethylene oxide as drug delivery nanocarrier in Pgp expressing multidrug-resistant cells (Cambón et al., 2013a; Cambón et al., 2013b), where the copolymer was shown to have comparable drug retention effect but no dire side effects in contrast to verapamil.

Molecules involved in MDR1 regulation and stability offer another approach to evade multidrug resistance in cancer. Compared to normal cells, regulation of Pgp expression in cancer cells involves complex molecular pathways. This complexity is largely associated with transformation associated features like unusual oxidative stress, glucose deprivation, hypoxia and metabolic acidosis. It had been demonstrated that both Protein kinase C (PKC) and Protein kinase A (PKA) phosphorylate Pgp at several serine residues (Chambers et al., 1993; Orr et al., 1993). These phosphorylation events are important in modulating the stability and enhancing drug translocating capacity of Pgp. Chemical inhibitors of PKC isoforms successfully demonstrated Pgp inhibition and restored drug sensitivity in MDR cells (Bates et al., 1992; Chambers et al., 1992). Several kinases like Ras/MAPK, JNK, p38 MAPK, PKA and PKC-related proteins, and PI3K, which are all implicated in tumorigenesis, also play a paramount role in Pgp expression. Therefore, strategies have been adopted to attain Pgp inhibition through attenuation of these signal transduction pathways (Callaghan et al., 2014).

Besides, there are several other stages of Pgp turnover like trafficking and recycling, ubiquitin-proteasomal degradation and glycosylation, which can well be harnessed to contend MDR in cancers (Katayama, Noguchi, and Sugimoto 2014).

\subsection{Nanomaterials in cancer treatment}

Any particulate substance that has at least one dimension less than $100 \mathrm{~nm}$ is called nanoparticle (NP) (Laurent et al. 2008) and the science that deals with nanomaterials is nanotechnology. Nanoparticle synthesis is mainly executed by two conventional methods called bottom-up and top-down approaches. Under controlled thermodynamic conditions nanoparticles generally attain spherical shape upon synthesis. Recent advancement of preparation methods have greatly improved the feasibility to synthesize non-spherical nanoparticles such as rods, tubes, triangles, diagonals, round surfaces, cubes and pyramids as well. Several physicochemical properties like electronic, optical, magnetic, mechanical 
and thermal properties are largely contingent on nanoparticle shape and size. Nanoparticles are broadly classified as carbon-based nanoparticles e.g. fullerene and carbon nanotubes, ceramic nanoparticles, polymeric nanoparticles e.g. nanospheres and nanocapsules, lipidbased nanoparticles, semiconductor nanoparticles and metal nanoparticles e.g. silver, cuprous and gold nanoparticles.

Nanomaterials due to their unique physical and chemical properties and their special interactions with biological systems hold great potential in the field of cancer biology. One of the foremost merits of nanomaterials in cancer diagnosis and treatment is their natural tumor targeting ability (solid tumors) via the enhanced permeability and retention effect (EPR effect) due to unusual permeability of intra-tumoral neovasculature. By angiogenesis, newly formed tumor blood vessels tend to be abnormal and leaky compared to normal vasculature (Cho et al., 2008; Ruoslahti et al., 2010). Hence, nanoparticles leaked through the fenestrations of the abnormal vasculature can accumulate in the tumor tissue. Thus, EPR effect forms a basis for passive targeting of cancer tissue by nanomaterials. Moreover, the large surface area of nanomaterials provides an advantage to customize their surface with biomolecules and ligands to specifically target cancer cells along with coated or conjugated payloads (Figure 2). The uniqueness of nanomaterials lies in their role as drug carriers and mediators of drug targeting, which is an apt combination for highly effective cancer therapy (Abdulkarim et al., 2012; Maria de Souza Antunes et al., 2011; Praetorius et al., 2008). Some nanomaterials that are of particular importance in cancer therapy encompass gold nanoparticles (AuNPs), polymeric nanoparticles, micelles and liposomes, magnetic nanoparticles, quantum dots (QDs) and carbon nanotubes (CNT). 


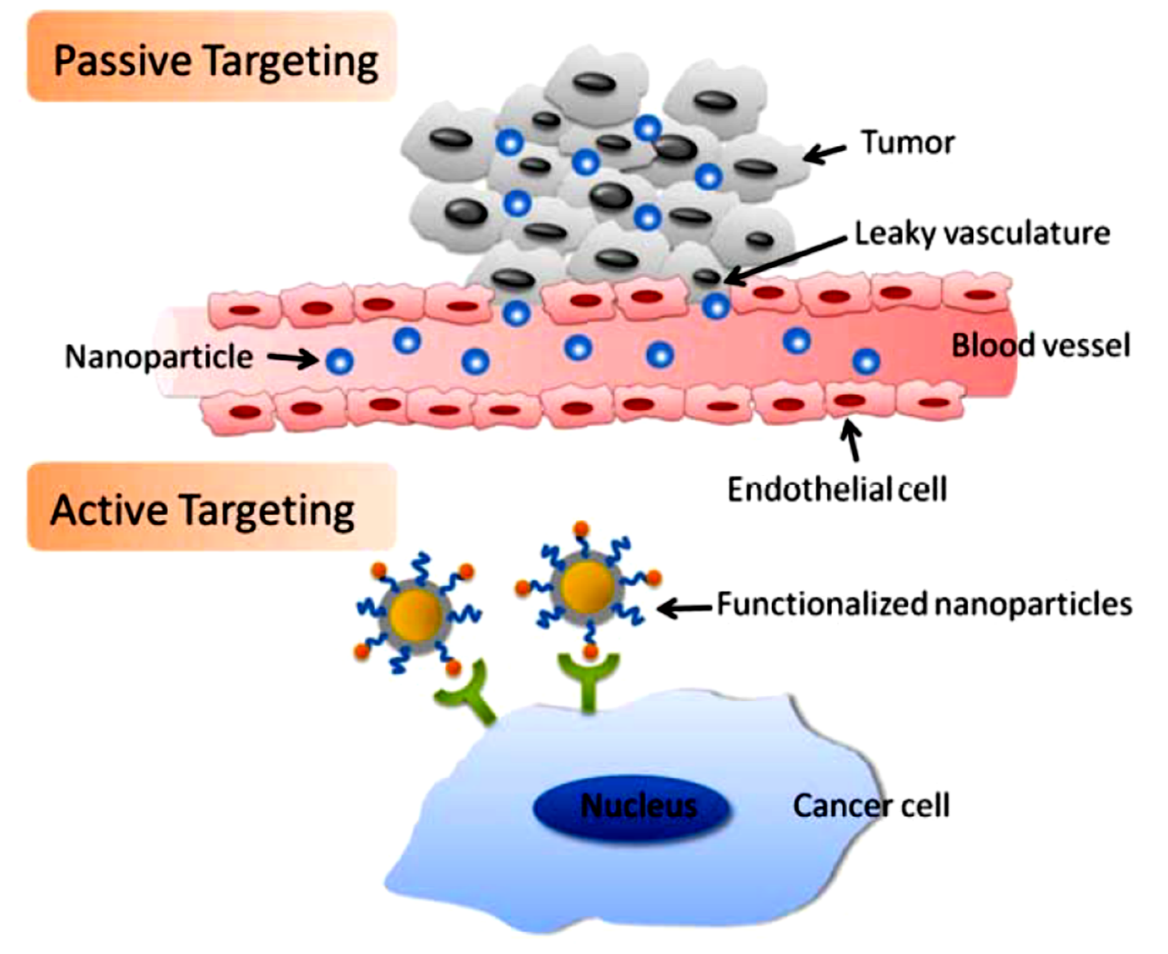

Figure 2: Passive and active targeting by nanoparticles (Yang et al., 2014)

\subsubsection{Silver nanoparticles (AgNPs)}

Although elemental Ag is associated with toxicity in animals and humans, colloidal Ag has been used for its medical values since ages. AgNPs are among the commonly produced and utilized nanoparticles today, where the production has reached more than 320 tons per year worldwide (Nowack et al., 2011). The biological activity of AgNPs has been extensively studied in recent years, thus their unique antibacterial, antifungal and antiviral features have already been characterized in details. At the same time, it was suggested that AgNPs might have a potential in cancer therapy owing to their prominent anti-proliferative and cytotoxic features (Rónavári et al., 2018; Tran et al., 2013). The majority of the biological properties of AgNPs depend on their size, on the coating material and the surface charge. AgNPs release Ag ions from their surface, which is the prime determinant of their biological value (Limbach et al., 2007; Lubick, 2008; Park et al., 2010). Studies have suggested that these released Ag ions are responsible for the toxicity of AgNPs (Limbach et al., 2007; Lubick, 2008; Park et al., 2010), since Ag ions trigger the production of superoxide radicals and other ROS, which in turn induce the expression of stress responserelated genes and cellular apoptosis. However, other reports suggest that AgNP-induced toxicity is not solely dependent on Ag ion release but it might be the result of other, $\mathrm{Ag}$ 
ion-independent molecular events elicited by AgNPs. Numerous in vitro and in vivo studies addressing the toxicity of AgNPs demonstrated that the size of AgNPs is one of the key determinants behind their cytotoxicity and other biological properties. In one such in vivo study authors have reported that regardless of the coating material, AgNP size regulates their organ targeting and cytotoxic features with $10 \mathrm{~nm}$ AgNPs being more toxic compared to $40 \mathrm{~nm}$ and $100 \mathrm{~nm}$ AgNPs (Recordati et al. 2016). In another study, mice treated with $10 \mathrm{~nm}$ AgNPs showed higher toxicity and impacted cell proliferation with a greater extent compared to $60 \mathrm{~nm}$ and $100 \mathrm{~nm}$ counterparts (Y. M. Cho et al. 2018). In general, smaller AgNPs tend to have more deleterious effects compared to larger sized AgNPs owing to their high surface to volume ratio, a faster rate of cellular internalization and a much broader organ targeting efficiency (Ahamed, AlSalhi, and Siddiqui 2010). Nevertheless, a wide array of molecular pathways are maneuvered by AgNPs, which feature is immensely valuable in cancer management since these can be exploited in cancer treatment (Gurunathan et al., 2009; Kawata et al., 2009; Kim et al., 2013; Kovács et al., 2016; Simard et al., 2016; Stępkowski et al, 2014).

\subsubsection{AgNPs induce the formation of reactive oxygen species (ROS)}

Reactive oxygen species (ROS) are byproducts of cellular oxygen metabolism primarily generated in mitochondria. Uncontrolled production of ROS culminates in severe cellular consequences by damaging DNA, vital proteins and lipids leading to apoptosis (Franco et al., 2009). In eukaryotes a range of anti-oxidant mechanisms encompassing enzymatic systems including superoxide dismutase (SOD), catalase, glutathione peroxidase (GPx), glutathione S-transferase (GST) and peroxiredoxins, as well as nonenzymatic components such as glutathione (GSH) and several vitamins (Franco et al. 2009) ensure to keep a balanced redox status and normal intracellular physiology. One of the well-studied biological properties of AgNPs is their potential to induce the formation of massive amounts of reactive oxygen species (ROS). A number of in vitro and in vivo studies have ascertained that AgNPs induce ROS generation also in cancer cells and cause apoptosis (Abdal Dayem et al., 2017; Chae et al., 2009; Choi et al., 2010; Griffitt et al., 2009; Posgai et al., 2011; Rahman et al., 2009). It was also reported that AgNP exposure leads to elevated lipid peroxidation (Arora et al., 2009), protein carbonylation (Haase et al. 2011), increased GSH levels (Arora et al., 2009; Farkas et al., 2011), it induces oxidative stress-related genes like heme oxygenase-1, metallothionein-2A (Miura et al., 2009) and the expression of redox-sensitive genes such as MAPK, Nrf-2 and NF-kB (Eom et al., 2010; Nishanth et al., 
2011), and raise the activity of antioxidant enzymes like SOD and catalase (Kim et al. 2009) in several cancer cell lines.

Several deranged cellular mechanisms in cancers compromise mitochondrial function and anti-oxidant systems (Yang et al., 2018), therefore, high ROS generation is an inevitable cosequence and represent one of the common hallmarks of cancers. It has been known that unregulated ROS generation is strongly linked to various aberrations in DNA integrity including base damage, DNA single-strand breaks, and DNA double-strand breaks, rearrangement of DNA sequence, DNA lesions and gene amplification, which are all associated with the activation of proto-oncogenes and inactivation of tumor suppressor genes finally leading to cancer (Levine et al. 2017). Despite their negative effects, ROS are key constituents in regulation of signalling pathways involved in cell survial and death such as MAPK/Erk1/2, PI3K/Akt and IKK/NF-kB (Liou et al., 2010). Therefore, cancer cells maintain a certain threshold level of ROS for maximum survival benefit, so any further elevation in ROS levels can overturn this balance and lead to cancer cell death. In fact, many chemotherapeutic strategies are designed to further elevate ROS generation in cancer, which irreparably damages tumor cells and culminates in apoptosis (Trachootham et al., 2009). Hydrogen peroxide a potent ROS generator induces apoptosis in Evil transformed cells indicating a vulnerability of cancer cells to elevated ROS generation (Roy et al. 2010). We recently reported that AgNPs induce cytotoxicity mediated through mitochondrial stress in osteosarcoma cells independent of their p53 status (Kovács et al., 2016). Therefore, optimized use of AgNPs alone (Jeyaraj et al., 2013; Kovács et al., 2016) or as an adjuvant along with chemotherapeutic drugs (Guo et al., 2015) might provide an appealing cancer chemotherapeutic strategy.

\subsubsection{AgNPs exert anti-proliferative effects}

From initiation to culmination, cell proliferation is precisely regulated at several points such as growth factor receptors, signal transduction pathways, cell cycle check points and pro- and anti-apoptotic regulators. Factors that intervene in any of the above-mentioned regulatory points would have a negative impact on proliferation. Unregulated proliferation is a fundamental phenomenon in cancers, which is achieved by gaining control over those regulatory mechanisms through genetic aberrations.

Cell cycle check points are set to keep the cell cycle progressing error-free. A multifactorial regulation orchestrated by DNA mutation proofreading DNA polymerases, 
DNA repair mechanisms and DNA damage sensory systems ensure to maintain the integrity of DNA that is passed onto the next generation. Whereas, cells with irreparably damaged DNA undergo apoptosis blocking the transfer of mutations. Tumor suppressor protein p53 is one of such DNA damage regulated apoptosis inducers. Loss of function mutations in p53 are well known for their carcinogenic potential. AgNPs induce DNA double-strand breaks and chromosomal aberrations (Ahamed et al., 2008; Asharani et al., 2009). Hui Kheng Lim et al. have noticed that the AgNP-induced DNA damage is more prominent in those cells that lack DNA dependent protein kinase (DNA-PK) (Lim et al., 2012). In a recent study, the authors have reported the antiproliferative effect of different sizes of AgNPs in pancreatic ductal carcinoma (Zielinska et al., 2018), and in addition, they observed elevated p53 and pro-apoptotic Bax levels and lowered anti-apoptotic Bcl-2 levels. Asha Rani et al. have found that AgNP-induced intracellular calcium transients trigger significant cellular stress and anti-proliferative effects (Asharani et al., 2009). Another study demonstrated a multimode anticancer activity of AgNPs through inhibition of cell proliferation, elevated DNA damage, decreased DNA damage repair and induction of apoptosis (Asharani et al., 2012).

Reorganization of the cytoskeleton is an important phenomenon during cell cycle (Hohmann et al., 2019). Aberrations in cytoskeletal organization have significant involvement in cell proliferation (Hohmann et al. 2019), migration (Roche 2018) and apoptosis (Povea-Cabello et al. 2017). Some recent reports showed negative impacts of AgNPs on cytoskeletal dynamics (Cooper et al., 2015; Kang et al., 2016). Therefore, further studies in this direction are suggestive to formulate an appealing intervention to manage cancers.

\subsubsection{Anti-angiogenic property of AgNPs}

Constantly growing mass of solid tumors face a major hurdle at their core due to limited or complete lack of nutrients and of oxygen supply (Folkman 1971). Tumors without vasculature would not grow beyond $2 \mathrm{~mm}^{3}$ (Muthukkaruppan et al., 1982) and consequently undergo cell death (Parangi et al. 1996). Therefore, angiogenesis, the growth of new blood vessels is indispensable for successful cancer growth and dissemination to distant places (metastasis). Among many factors, VEGF and bFGF are particularly important in cancer-induced angiogenesis (Mousa 1998). Silver nanoparticles, produced by green synthesis have been shown to exhibit anti-angiogenic properties in embryonated 
chicken model (Bahara et al., 2014; Khandia et al., 2015) emphasizing the potential use of silver nanoparticles as anti-angiogenics is cancer therapy. Gurunathan and colleagues have reported the angiogenesis inhibitory potential of silver nanoparticles via inhibition of $\mathrm{PI} 3 \mathrm{~K} /$ Akt signalling pathways in bovine retinal endothelial cells induced with VEGF (Gurunathan et al. 2009) and eventually apoptosis in tumor tissue due to underdevelopment of neovasculature (Kalishwaralal et al. 2009).

\subsubsection{AgNPs trigger endoplasmic reticulum stress}

In addition to the above-explained cytotoxic mechanisms, AgNPs can also induce cell death by other mechanisms such as endoplasmic reticulum stress (Mao et al., 2016). Endoplasmic reticulum (ER) with its unique intraluminal environment (i.e. redox state and calcium concentration) operates optimal protein folding and homeostasis. Therefore, perturbations of any kind that impede its protein folding machinery lead to ER stress and eventually to "unfolded protein response" (UPR). UPR is primarily an adaptive response, it attempts to minimize the number of proteins that enter the ER to attain folding under these circumstances and it also upregulates ER chaperones like Grp78/Bip and Grp94 that assist in improving protein folding. UPR also activates proteins related to the process called Endoplasmic Reticulum Associated Protein Degradation (ERAD) such as proteasomal degradation and autophagy (Rashid et al. 2015) that helps in relieving the burden of unfolded and aggregated proteins on ER, and proteins related to cell survival and apoptosis inhibition as well. Constitutive ER stress turns into UPR as a maladaptive response that activates programmed cell death mechanisms by upregulating ER stress regulated cell death mediator GADD153/CHOP (Oyadomari et al., 2004). ROS are the key drivers of ER stress (Cao et al., 2014), therefore mounting evidence indicates ER stress as one of the indispensable cellular consequences associated with AgNPs treatment (Asharani et al., 2009; Zhang et al. 2012). However, ROS-independent mechanisms have also been reported with AgNPs treatment (Christen et al., 2013).

\subsubsection{AgNPs against multidrug resistance}

There have been several reports proving the effective application of nanoparticles in multidrug-resistant cancers to improve the outcome of chemotherapy. Doxorubicin loaded poly-(alkyl-cyanoacrylate) nanoparticles proved to successfully and effectively deliver doxorubicin by masking it from Pgp recognition (Pepin et al., 1997; Vauthier et al., 2003). Systemic administration of camptothecin-polymer IT-101 showed a quite appealing 
increment in drug sensitivity in H69 small-cell lung cancer, Panc-1 pancreatic cancer, MDA-MB-231 breast cancer and TC71-luc Ewing's sarcoma mouse cancer xenografts (Schluep et al. 2006). In addition to drug loaded polymeric nanoparticles, nanoparticles conjugated with drugs along with ligands that target cell surface receptors have also been proved efficient in bypassing drug recognition of Pgp (Lee et al., 2005; Sahoo et al., 2004; Suzuki et al., 2008). Bypassing Pgp's drug recognition is the key mechanism behind the success of all those explained nanoparticle-mediated drug delivery strategies. However, only a few reports showed so far any direct effect of AgNPs on Pgp function or expression. As a first-ever available evidence, the authors demonstrated an effective inhibition of Pgp efflux activity by TAT-modified AgNPs of $8 \mathrm{~nm}$ size, and implied a physical blockade of the $3 \mathrm{~nm}$ diameter Pgp channel by AgNPs (Liu et al. 2012). In a recently published report from our lab, we show evidence of inhibiting Pgp expression in MDR cells treated with AgNPs (Kovács et al., 2016). In this study, we revealed that $28 \mathrm{~nm}$ AgNPs downregulate Pgp transcript and protein levels and thereby inhibit Pgp-mediated drug efflux in multidrugresistant Colo 320 cells. These reports infer that molecular mechanisms underlying Pgp inhibitory capacity of AgNPs depend on their size. Therefore, in the present study, we examined Pgp inhibitory potential of two differently sized AgNPs in multidrug-resistant breast adenocarcinoma cells and verified various molecular mechanisms affected by AgNPs that underlie their Pgp inhibitory activity. 


\section{AIMS OF THE STUDIES}

Specific goal of the present thesis was to study the size-dependent effect of silver nanoparticles in inhibiting P-glycoprotein efflux function in multidrug-resistant breast cancer cells in vitro. Our special focus was to unravel the molecular and cellular mechanisms that have been influenced by AgNPs to realize the inhibitory action on P-glycoprotein efflux activity. For this, we synthesized quasi-spherical citrate coated silver nanoparticles of two different sizes and used them to treat P-glycoprotein overexpressing MCF-7/KCR cells that were developed from MCF-7 breast cancer cells as a multidrug-resistant cancer model.

Thus, the aims of the present thesis are:

1. To examine which of silver nanoparticles (smaller or larger diameter) are more efficient in inhibiting drug efflux via Pgp in MDR breast cancer cells.

2. To study the capacity of AgNPs to sensitize multidrug-resistant breast adenocarcinoma cells to drug-induced cell death.

3. To verify if transcriptional and/or translational modulation of Pgp levels are involved in the AgNP-induced molecular mechanisms in MDR cancer cells

4. To examine the connection of Pgp inhibition to mitochondrial damage associated with the ROS generating potential of AgNPs.

5. To relate the Pgp inhibitory potential of AgNPs to their ER stress inducing capacity. 


\section{MATERIALS AND METHODS}

\subsection{Cell culture}

The MCF-7 human breast adenocarcinoma cell line was purchased from ATCC. The drugresistant MCF-7/KCR cell line was developed from MCF-7 under doxorubicin selection pressure from $10 \mathrm{nM}$ to $1 \mu \mathrm{M}$ (Kars et al., 2006; Molnar et al., 2008). Cell lines were maintained and treatments were applied in RPMI-1640 (LONZA) medium supplemented with 10\% FBS (EuroClone), $2 \mathrm{mM}$ glutamine (Sigma) and $1 \mathrm{ml}$ penicillin-streptomycin $\left(10^{7} \mathrm{U} / \mathrm{L}\right)$ solution (BIOSERA INC.) at $37^{\circ} \mathrm{C}, 5 \% \mathrm{CO}_{2}$ and $95 \%$ humidity. To maintain the drug-resistant phenotype, MCF-7/KCR cells were cultured in media with and without $1 \mu \mathrm{M}$ doxorubicin (MedChemExpress) for 1 week each. Before experiments, MCF-7/KCR cells were grown in doxorubicin-free medium. Cell cultures were maintained by regular passaging with $5 \mathrm{x}$ trypsin (ThermoFisher) until 15 passages.

\subsection{Synthesis and characterization of AgNPs}

Citrate-capped silver nanoparticles were synthesized according to Wan et al. with modifications (Wan et al. 2013). Briefly, to obtain $5 \mathrm{~nm}$ AgNPs, $75 \mathrm{~mL}$ water and $20 \mathrm{~mL} \mathrm{1 \%}$ citrate solution (Sigma-Aldrich) were mixed and heated, then $1.7 \mathrm{~mL}$ of $1 \% \mathrm{AgNO}_{3}$ solution (Sigma-Aldrich) and $2 \mathrm{~mL}$ of $0.1 \% \mathrm{NaBH}_{4}$ solution (Sigma-Aldrich) were added under vigorous stirring at $70^{\circ} \mathrm{C}$. The resulting AgNPs were used as starter seeds for larger AgNPs in a stepwise growth approach by adding $2 \mathrm{~mL}$ of $1 \%$ citrate solution, $75 \mathrm{~mL}$ water and $2 \mathrm{~mL}$ of $1 \% \mathrm{AgNO}_{3}$ in three subsequent cycles. Morphology and size distribution of the synthetized nanoparticles was characterized by transmission electron microscopy using FEI Tecnai G2 20× microscope at $200 \mathrm{kV}$ acceleration voltage and by Dynamic Light Scattering using Malvern Zetasizer Nano instrument.

\subsection{Rhodamine 123 accumulation assay}

Cells were seeded at a density of $2 \times 10^{6}$ cells/well in 6-well plates and incubated for 24 hours at $37^{\circ} \mathrm{C}, 5 \% \mathrm{CO}_{2}$ and $95 \%$ humidity. On the next day cells were washed twice with PBS and were treated in triplicates with either $5 \mathrm{~nm}$ or $75 \mathrm{~nm}$ AgNPs in $150 \mu \mathrm{M}$ concentration for 65 hours or with verapamil in $40 \mu \mathrm{M}$ concentration for 2 hours. All the treatments were given in RPMI-1640 complete cell culture media containing 10\% FBS, $2 \mathrm{mM}$ glutamine and $1 \mathrm{~mL}$ penicillin-streptomycin $\left(10^{7} \mathrm{U} / \mathrm{L}\right)$ solution. After the treatments, cells were washed twice thoroughly with PBS to wash off AgNPs and were resuspended in serum-free RPMI-1640 
medium containing $10 \mu \mathrm{M}$ of Rhodamine 123 (RH123, Sigma-Aldrich) and cells were incubated with this solution for 2 hours at $37{ }^{\circ} \mathrm{C}, 5 \% \mathrm{CO} 2$ and $95 \%$ humidity in dark. Then cultures were washed with PBS and were trypsinized to collect cells. Cells were washed again with ice cold PBS to remove debris and trypsin, then were resuspended in $500 \mu \mathrm{L}$ ice cold PBS and were light protected until they were taken to flowcytometry (FACS) analysis. RH123 fluorescence of at least 10,000 cells/ sample were measured by FACS using FACSCalibur ${ }^{\mathrm{TM}}$ platform. Data were analysed by FlowJo V10 software. Results were obtained from triplicates.

\subsection{Preparation of plasma membrane and cytoplasmic fractions}

MCF-7/KCR cells were seeded in $100 \mathrm{~mm}$ cell culture dishes at a density of $2 \times 10^{6}$ cells/dish. 24 hours post-seeding cells were treated with $75 \mathrm{~nm} \mathrm{AgNPs}$ in $150 \mu \mathrm{M}$ concentration for 65 hours. Both the control and the treated MCF-7/KCR cells were collected in TNM buffer (10 mM Tris- $\mathrm{HCl}(\mathrm{pH} 7.4), 10 \mathrm{mM} \mathrm{NaCl}, 1.5 \mathrm{mM} \mathrm{MgCl}_{2}$ ) and were homogenized using glass beads. All chemicals and glass beads were purchased from Sigma. Lysates were centrifuged at $2000 \mathrm{x}$ g, the supernatant was collected and centrifuged at $8000 \mathrm{x}$ g at $4{ }^{\circ} \mathrm{C}$ using Sorvall-RC$28 \mathrm{~S}$ centrifuge. The supernatant was considered as cytoplasmic fraction. The pellet containing the membrane fraction was resuspended in $1 \mathrm{~mL}$ ice cold TNM buffer and was layered on TNM buffer containing 36\% sucrose. Samples were centrifuged (Sorvall-WX-Ultra80) at 100,000 x $\mathrm{g}$, at $4{ }^{\circ} \mathrm{C}$ overnight. The interphase was collected and was subjected to protein precipitation using trichloroacetic acid. After centrifugation at 18,000 $\mathrm{x}$, the pellet was washed with

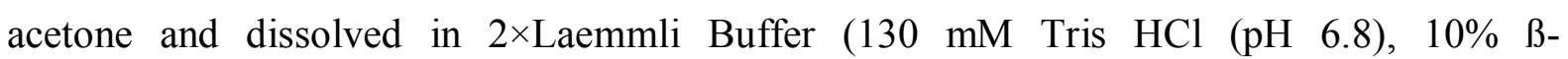
mercaptoethanol, 4\% SDS, $20 \%$ glycerol, $0.01 \%$ bromophenol blue, all chemicals were from Sigma), which was considered as plasma membrane fraction.

\subsection{Immunoblotting}

MCF-7/KCR cells were seeded to 6 -well plates at a density of $10^{5}$ cells/well and were treated with $5 \mathrm{~nm}$ or $75 \mathrm{~nm}$ AgNPs in $150 \mu \mathrm{M}$ concentration or with positive controls such as $10 \mu \mathrm{M}$ rapamycin (autophagy) (Sigma), 2 mM DTT (ER stress) (Sigma) and $10 \mu \mathrm{g} / \mathrm{mL}$ M627 (apoptosis). After the treatment whole cell extracts were prepared using freshly prepared RIPA lysis buffer (50 mM Tris (pH:7.4), $150 \mathrm{mM} \mathrm{NaCl}, 1 \mathrm{mM}$ EDTA, 1\% Triton X-100 and $1 \mathrm{x}$ PIC). To detect cytoplasmic cytochrome c protein levels cells were lysed in sonication buffer (50 mM Tris, $2 \mathrm{mM}$ EDTA, $0.5 \mathrm{mM}$ DTT, $50 \mathrm{mM} \mathrm{NaCl}, 1 \mathrm{x}$ PIC). Mitochondrial fraction was sedimented by centrifuging at $16,000 \mathrm{x} \mathrm{g}$ and supernatants were collected. The protein concentrations were measured using the Bradford method. $25 \mu \mathrm{g}$ of protein from whole cell 
lysates, cytoplasmic or plasma membrane fractions were diluted with MilliQ water, mixed with equal volume of $2 \mathrm{x}$ loading buffer (100 mM Tris- $\mathrm{Cl}$ (pH 6.8), 4\% SDS, $0.2 \%$ bromophenol blue, $20 \%$ glycerol and $200 \mathrm{mM} \beta$-mercaptoethanol) and heated at $95^{\circ} \mathrm{C}$ for five minutes. Prepared protein samples were resolved either or on 12\% SDS-PAGE (for cytochrome c and LC3), 10\% SDS-PAGE (for Pgp, Grp94, Grp78, GADD153, EDEM and Na/K-ATPase) along with protein molecular weight marker (Thermo Fisher Scientific) at 100V for 1 hour 30 minutes. Resolved protein samples were transferred to nitrocellulose (PVDF for LC3 western blots) membrane (Amersham) at $150 \mathrm{~mA}$. Successful protein transfer was confirmed with Ponceau red staining. Membranes were blocked with 5\% non-fat dry milk in TBST (20 mM Tris, $150 \mathrm{mM} \mathrm{NaCl}$ and $0.05 \%$ Tween20) for 2 hours and washed thrice with TBST. Membranes were incubated overnight with primary antibodies (Table 4) diluted in TBST containing $1 \%$ non-fat dry milk. After overnight incubation, membranes were washed thrice with TBST and species-specific HRP-conjugated secondary antibodies (DAKO) diluted in TBST containing 1\% non-fat dry milk were applied for 2 hours at room temperature. Membranes were washed 3 times with TBST and were developed with ECL reagent (Millipore). Membranes were visualized by C-DiGit Blot Scanner (LI-COR). Densitometry was performed using ImageJ software. The presented images are representative blots from three individual experiments.

Table 4: List of antibodies used in western blots

\begin{tabular}{c|ccc} 
Antibody & Manufacturer & Cat No & Dilution \\
\hline Grp94 & Santa Cruz & sc-13119 & $1: 1500$ \\
Grp78 & Santa Cruz & sc-376768 & $1: 250$ \\
GADD153 & Santa Cruz & sc-7351 & $1: 200$ \\
P-glycoprotein & Santa Cruz & sc-55510 & $1: 500$ \\
EDEM & Santa Cruz & sc-377394 & $1: 200$ \\
Cytochrome c & Abcam & ab13575 & $1: 500$ \\
LC3-A/B & Cell Signalling & 12741 & $1: 2000$ \\
Na K $^{+}$ATPase & Santa Cruz & sc-21712 & $1: 200$ \\
$\alpha$-tubulin & eBioscience & $14-4502-82$ & $1: 1000$
\end{tabular}

\subsection{Cell viability assay and $\mathrm{IC}_{50}$ determination}

MCF-7/KCR cells were seeded to 96-well plates at a density of $10^{4}$ cells/well and were left to grow for 24 hours. Next day, cells were treated either with $5 \mathrm{~nm}$ or $75 \mathrm{~nm}$ AgNPs in 50, 100, $150,200,250,300,350,400$ and $450 \mu \mathrm{M}$ concentration for 24 and $48 \mathrm{hrs}$. For combinational treatment cells were treated with $150 \mu \mathrm{M}$ AgNP. After 48 hours, the medium was replaced by 
a medium containing $150 \mu \mathrm{M}$ of $75 \mathrm{~nm}$ AgNPs and 10, 20, 30, 40, 50, 60, 70 and $80 \mu \mathrm{M}$ of doxorubicin and cells were incubated for further 24 hours. To avoid doxorubicin adsorption onto AgNP surfaces we first mixed AgNPs in the complete medium and added doxorubicin 1 hour later. Following treatments, cells were washed with PBS and were incubated with serum free RPMI-1640 medium containing $0.5 \mathrm{mg} / \mathrm{mL}$ MTT reagent (Sigma). Plates were placed in $\mathrm{CO}_{2}$ incubator for 2 hours for formazan crystals to be formed. After the incubation the medium was removed and cells were washed with PBS. Formazan crystals were solubilized in $100 \mu \mathrm{L}$ DMSO (MOLAR Chemicals) and gently stirred for complete solubilisation of crystals. Absorbance was measured at $570 \mathrm{~nm}$ using a Synergy HTX microplate reader (BIOTEK®). Measurements were repeated three times using 4 independent biological replicates. Absorbance values of the untreated control samples were considered as $100 \%$ viability and the absorbance values were normalized to the control. $\mathrm{IC}_{50}$ values were determined from the rationality curves using GraphPad prism software by selecting Log (inhibitor) vs normalized response-variable slope option.

\subsection{Apoptosis detection}

MCF-7/KCR cells were seeded at $2 \times 10^{6}$ cells/well density in 6 -well plates. On the following day cells were treated with $75 \mathrm{~nm}$ AgNPs at $150 \mu \mathrm{M}$ concentration and were incubated with these particles for 48 hours. After 48 hours, changed to the medium containing $150 \mu \mathrm{M}$ of $75 \mathrm{~nm} \mathrm{AgNPs}$ and $20 \mu \mathrm{M}$ doxorubicin and cells were incubated for further 24 hours. Positive control was treated with $20 \mu \mathrm{M}$ doxorubicin and $4 \mu \mathrm{M}$ verapamil for 24 hours. We also treated a separate set of cells with $20 \mu \mathrm{M}$ doxorubicin alone for 24 hours. Cells were collected by scraping in ice cold PBS. Dead Cell Apoptosis Kit containing AnnexinV-FITC and propidium iodide (Life Technologies) was used according to the manufacturer's recommendation. Fluorescence intensities of at least 10,000 cells/sample were measured by FACSCalibur ${ }^{\mathrm{TM}}$ and data were analysed by FlowJo V10 software. Experiments were repeated three times using at least three independent biological replicates.

\subsection{JC-1 staining}

JC-1 is a ratiometric dye that exhibits mitochondrial membrane potential dependent accumulation. JC-1 aggregates in healthy mitochondria and fluoresces in red, whereas JC-1 monomers diffused in the cytoplasm exhibit green fluorescence. Red-to-green fluorescence ratio of JC-1 indicates mitochondrial health and changes due to modulated mitochondrial membrane potential. To measure mitochondrial membrane potential via JC-1 staining, cells 
were seeded onto cover slips placed into 24 -well plates $\left(10^{5}\right.$ cells/well). Before seeding coverslips were coated with $2 \%$ gelatine (Sigma). On the next day cells were treated with 150 $\mu \mathrm{M}$ of $5 \mathrm{~nm}$ or $75 \mathrm{~nm}$ AgNPs for $48 \mathrm{~h}$ or with apoptosis inducer M627 (12Hbenzo \{alpha\}phenothiazine) (Varga et al. 2005) in $50 \mu \mathrm{g} / \mathrm{mL}$ concentration for $24 \mathrm{~h}$. JC- 1 is a Pgp substrate, hence before JC-1 loading, $40 \mu \mathrm{M}$ of the Pgp inhibitor verapamil was added to the samples. After an hour cells were washed and incubated with RPMI-1640 medium containing $10 \mu \mathrm{g} / \mathrm{mL} \mathrm{JC}-1$ (Life Technologies) for $15 \mathrm{~min}$. Cover slips were inversely mounted in Fluoromount ${ }^{\mathrm{TM}}$ (ThermoFisher) on glass slides and JC-1 fluorescence was visualized by OLYMPUS BX51 microscope equipped with Olympus DP70 camera using the same exposition time for all samples. Image analysis was performed by ImageJ software. Experiments were repeated three times using three independent biological replicates.

\subsection{Detection of ROS}

2',7'-dichlorofluorescein diacetate (DCFDA) staining method was used to detect ROS production upon both $5 \mathrm{~nm}$ and $75 \mathrm{~nm}$ AgNP treatments. Cells were seeded at $10^{5}$ cells/well density onto $2 \%$ gelatine coated cover slips placed in $24-w e l l$ plates. On the next day cells were treated with $150 \mu \mathrm{M}$ of AgNPs for $48 \mathrm{~h}$, then were incubated with RPMI-1640 medium containing $10 \mu \mathrm{M}$ DCFDA (Sigma-Aldrich) in dark for $20 \mathrm{~min}$. Cover slips were mounted on glass slides, and DCF fluorescence was visualized by OLYMPUS BX51 microscope equipped with Olympus DP70 camera using the same exposition time for all samples. Fluorescence intensity measurements were performed using ImageJ software. Measurements were repeated three times.

\subsection{Reverse transcription and real-time RT-PCR}

MCF-7/KCR cells were seeded at $2 \times 10^{6}$ cells/well density in 6-well plates. 24 hours post seeding cells were treated with $5 \mathrm{~nm}$ and $75 \mathrm{~nm}$ AgNPs at $150 \mu \mathrm{M}$ concentration for 48 hours. Positive control samples were treated with $2 \mathrm{mM}$ dithiothreitol (DTT) for 48 hours. After the treatment cells were washed with PBS and collected by trypsinization. Total cellular RNA was prepared using RNeasy ${ }^{\circledR}$ Mini Kit (QIAGEN) according to the manufacturer's recommendation and stored at $-80^{\circ} \mathrm{C}$ until further experiments. Two microgram RNA was reverse transcribed using Oligo $d(T)_{16}$ (TaqMan ${ }^{\circledR}$ Reverse Transcription kit, Applied Biosystems) in $40 \mu \mathrm{L}$ reaction mixture. Reverse transcription was performed on thermocycler (Applied Biosystems) using the program $25^{\circ} \mathrm{C}(10 \mathrm{~min}), 37^{\circ} \mathrm{C}(30 \mathrm{~min}), 95^{\circ} \mathrm{C}(5 \mathrm{~min}), 4^{\circ} \mathrm{C}$ (indefinite). The synthesized cDNA was stored at $-20^{\circ} \mathrm{C}$ until further experiments. Optimal 
primer sets for target genes were designed using primer blast (https://www.ncbi.nlm.nih.gov) and were ordered from ThermoScientific. Sequence of all the primers is listed in Table 5. Primers were dissolved in DEPC water (SERVA) to obtain $1 \mathrm{mM}$ stock concentration. These primer stocks were further diluted with DEPC water to $5 \mu \mathrm{M}$ working concentration and stored at $-20^{\circ} \mathrm{C}$. Quantitative real time PCR reactions were performed on PicoReal ${ }^{\mathrm{TM}}$ Real-time PCR (Thermo Scientific) using SYBR Green qPCR Master Mix (Thermo Scientific) with an input of $1 \mu \mathrm{L}$ cDNA. Each primer was used at $200 \mathrm{nM}$ concentration. Relative transcript levels were determined by the $\Delta \Delta \mathrm{Ct}$ analysis using GAPDH as reference gene. Experiments were repeated three times using three biological replicates.

Table 5: List of sequence of primers used in quantitative real-time PCR

\begin{tabular}{c|cc} 
Primer & Forward & Reverse \\
\hline Grp94 & 5'-CAGTTTTGGATCTTGCTGT-3' & 3'-CAGCTGTAGATTCCTTTGC-5' \\
Grp78 & 5'-TGTTCAACCAATTATCAGCAAACTC-3' & 3'-TTCTGCTGTATCCTCTTCACCAGT-5' \\
GADD153 & 5'-GGAGCATCAGTCCCCCACTT-3' & 3'-TGTGGGATTGAGGGTCACATC-5' \\
EDEM & 5'-TTGACAAAGATTCCACCGTCC-3' & 3'-TGTGAGCAGAAAGGAGGCTTC-5' \\
GAPDH & 5'-TGCACCACCAACTGCTTAGC-3' & 3'-GGCATGGACTGTGGTCATGAG-5'
\end{tabular}

\subsection{Cytoplasmic calcium release measurements}

MCF-7/KCR cells at $5 \times 10^{3}$ density were seeded to coverslips (Sarstedt) coated with $2 \%$ gelatine, placed in wells of 24-well plates inserted with coated coverslips, which formed the base of a perfusion chamber during real-time confocal microscopic analysis. 24 hours post seeding cells were treated with $75 \mathrm{~nm}$ AgNPs at $150 \mu \mathrm{M}$ concentration for 65 hours. Fluo4$\mathrm{AM}$ is a $\mathrm{Ca}^{2+}$-sensitive fluorescence dye, which is a substrate of P-glycoprotein. To maintain Fluo4-AM inside the cells we added a Pgp inhibitor Quinidine. We did not apply verapamil since it is an inhibitor of voltage-dependent calcium channels, which would influence calcium release measurements. 1 hour before the experiment we added Quinidine (Sigma) in $4 \mu \mathrm{M}$ concentration to cells preloaded with Fluo4-AM (Sigma) at $5 \mu \mathrm{M}$ for $20 \mathrm{~min}$ at $37{ }^{\circ} \mathrm{C}$. The chamber was mounted on the stage of a Zeiss LSM880 confocal laser scanning microscope and cells were bathed with standard HEPES solution $(140 \mathrm{mM} \mathrm{NaCl}, 5 \mathrm{mM} \mathrm{KCl}, 10 \mathrm{mM}$ HEPES acid, $1 \mathrm{mM} \mathrm{CaCl}_{2}, 1 \mathrm{mM} \mathrm{MgCl} 2,10 \mathrm{mM}$ glucose) for 5 minutes and switched to $100 \mu \mathrm{M}$ carbachol (Sigma) in HEPES for 2 minutes at $37^{\circ} \mathrm{C}$ at $5-6 \mathrm{~mL} / \mathrm{min}$ perfusion rate. All experiments were performed using a Plan-Apochromat 40X/1.4 oil immersion objective. In each experiment real-time calcium release was measured from a pre-set 6-10 region of interests (ROIs)/ cell. Changes in intracellular $\mathrm{Ca}^{2+}$ concentration were determined by excitation at 488 
$\mathrm{nm}$, with emitted light monitored at $516 \mathrm{~nm}$. Fluorescence signals were normalized to initial fluorescence intensity $(\mathrm{F} / \mathrm{F} 0)$ and expressed as relative fluorescence $(\Delta \mathrm{F} / \mathrm{F} 0)$, where $\Delta \mathrm{F}$ indicates the changes in fluorescence intensity and F0 is the baseline level.

\subsection{Transmission electron microscopy}

$10^{5}$ cells were grown on $0.4 \mu \mathrm{m}$ pore size polyester membrane inserts (Corning) for transmission electron microscopy (TEM) analysis. Next day samples were treated with $5 \mathrm{~nm}$ and $75 \mathrm{~nm}$ silver nanoparticles. 24 hours after AgNPs treatment cells were washed gently with PBS and fixed for 2 hours in $4 \%$ glutaraldehyde and then in $2 \%$ gelatin. The samples were embedded into epoxy resin (Epon 812, EMS, PA 19440) and sliced into $70 \mathrm{~nm}$ sections and collected on mesh grids. Samples were then stained with $25 \%$ uranyl acetate and $1 \%$ lead acetate. These TEM preparations were examined with $100 \mathrm{kV}$ accelerating voltage in Philips CM10 electron microscope equipped with Megaview G2 digital camera (ITEM, Olympus Soft Imaging Solution GmbH, Münster) located at University of Szeged Institute of Pathology. 


\section{RESULTS}

\subsection{Characterization of the synthesized silver nanoparticles and the cell lines}

a
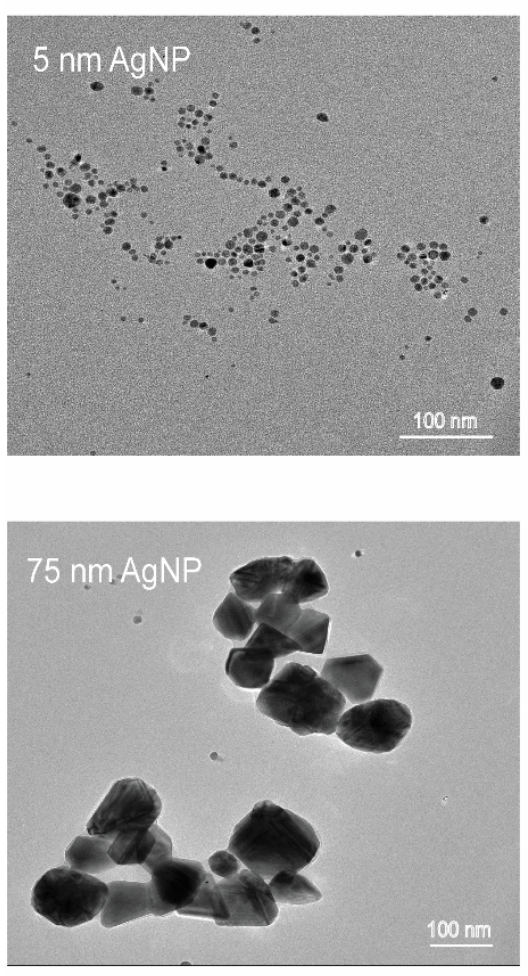

b

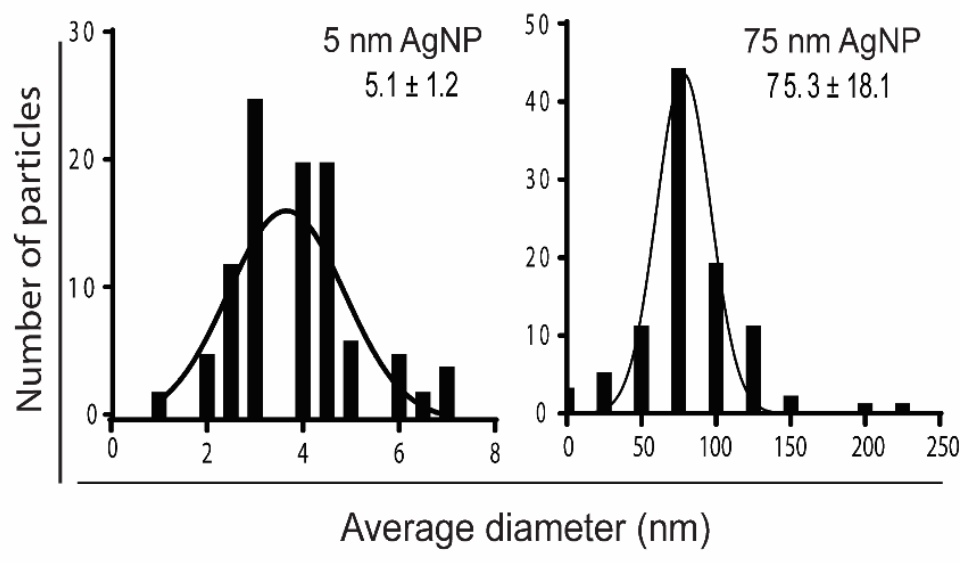

C

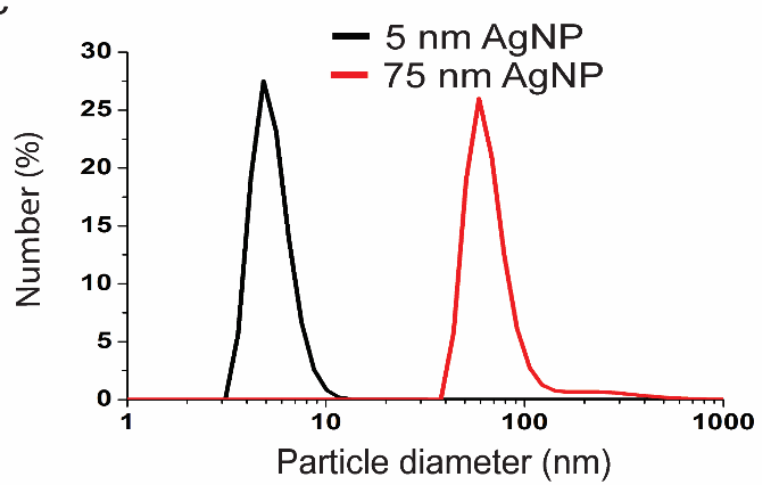

Figure 3: Characterization of silver nanoparticles. (a) Representative TEM micrographs of the synthesized citrate-coated AgNPs. (b) Size distribution and particle diameter of AgNPs by TEM image analysis and (c) by DLS.

Citrate coated silver nanoparticles of two different sizes were synthesized by using the method described in the section 3.2. The successful synthesis was verified by TEM and the particle size distribution was analysed both by TEM image analysis and dynamic light scattering (DLS) measurements. The representative figures (Figure 3a-c) indicate quasispherical silver nanoparticles with mean sizes of $5 \mathrm{~nm}$ and $75 \mathrm{~nm}$ diameter.

To examine the biological properties of AgNPs, cells were treated with AgNPs diluted in cell culture media supplemented with FBS. Nanomaterials adsorb various biomolecules such as proteins on their surface leading to the formation of a protein corona. This protein corona contributes to colloidal stability thus influences aggregation and biological properties of 
AgNPs (Bélteky et al. 2019). In order to test nanoparticle colloidal stability in serum containing cell culture media, AgNP aggregation grade was measured in DMEM with 10\% FBS and in water as a reference, using dynamic light scattering in a time dependent manner. We observed the changes in the average hydrodynamic diameter (Z-average) and zeta potential of the samples throughout the 2-hour measurement. The results demonstrate that both $5 \mathrm{~nm}$ and 75 $\mathrm{nm}$ AgNPs showed similar tendencies in forming biomolecular corona in serum containing cell culture media indicative of their colloidal stability (Figure 4).
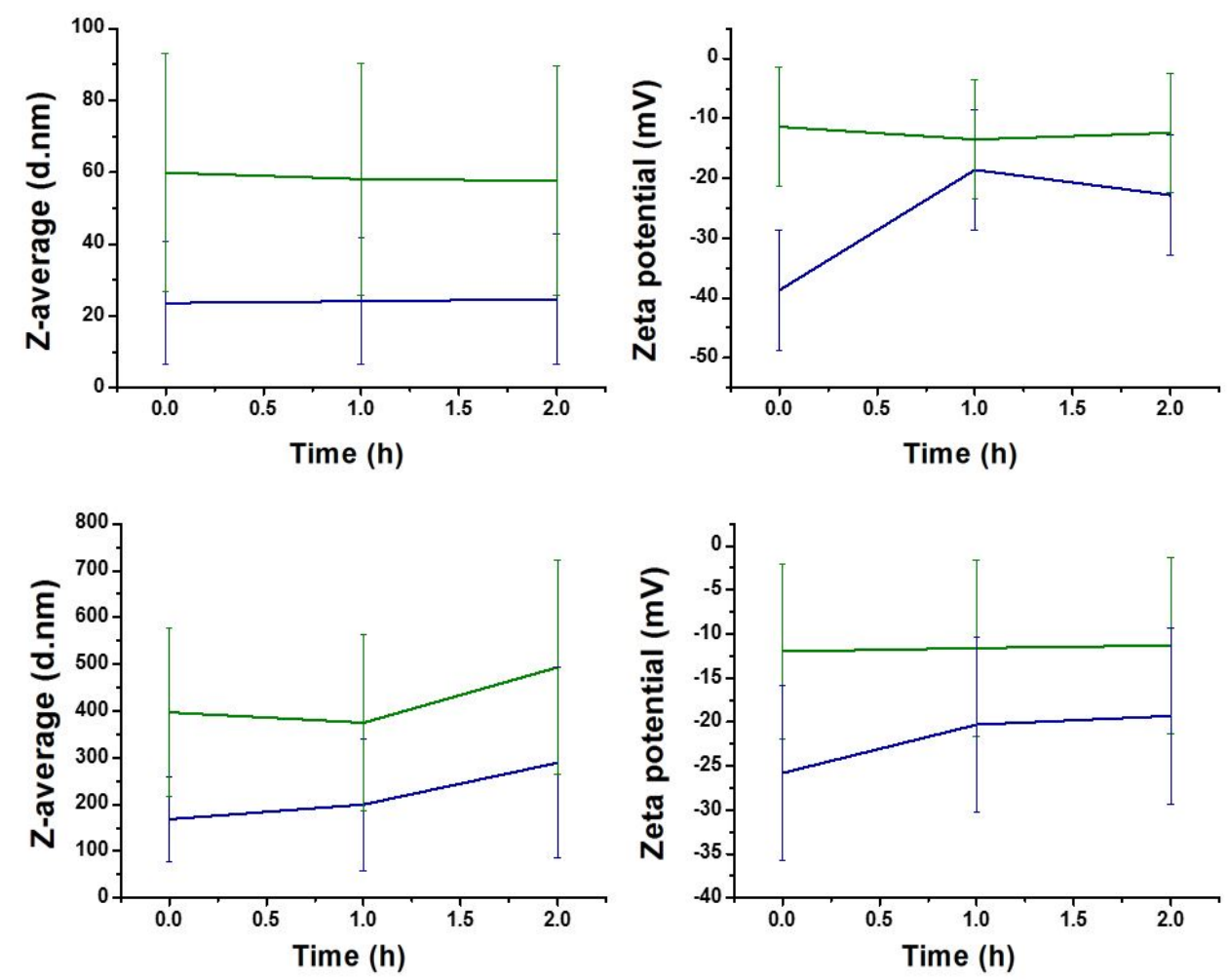

Figure 4: Hydrodynamic diameter and zeta potential of AgNPs. Average hydrodynamic diameter (Z-average) and zeta potential values of $5 \mathrm{~nm}$ (upper panels) and $75 \mathrm{~nm}$ (lower panels) silver nanoparticles in DMEM $+10 \%$ FBS (Green) and in water as reference (Blue)

In order to verify the effects of these two differently sized AgNPs, in the present study we used two human cell lines: MCF-7 breast adenocarcinoma and the Pgp overexpressing, multidrug-resistant MCF-7/KCR cell line, which was developed from MCF-7 cells through prolonged exposure to gradually increasing doses of doxorubicin from $10 \mathrm{nM}$ to $1 \mu \mathrm{M}$ (Kars et al., 2006). Although the precise mechanism underlying MDR1 overexpression in MCF-7/KCR cells is not completely known, transcription provoking histone $\mathrm{H} 3$ lysine 9 acetylation at the 
MDR1 promoter has been reported in these cells (Toth, Boros, and Balint 2012), nevertheless, additional mechanisms can't be ruled out. To verify Pgp expression and efflux activity in MCF7/KCR cells we performed western blot and RH123 efflux assay, respectively, and compared these features with those of the drug sensitive MCF-7 cells. RH123 is a fluorescent dye and is a substrate of Pgp, its intracellular accumulation reflects Pgp efflux function (Forster et al., 2012). FACS histograms (Figure 5a) of RH123 loaded cells indicate that total intracellular accumulation of RH123 in MCF-7/KCR cells is significantly lower than in MCF-7 cells complying with enhanced efflux of Pgp substrates by MCF-7/KCR cells. A first-generation Pgp inhibitor verapamil effectively inhibited the exclusion of RH123 indicating that the elevated efflux activity of MCF-7/KCR cells is mainly the result of Pgp overexpression. Western blot images (Figure 5b) clearly show that MCF-7/KCR cells express a massive amount of Pgp, while the drug-sensitive MCF-7 cells lack or express very low amount of this $A B C$ transporter (below the detection level of western blot).

a

$$
\begin{aligned}
{ }_{800} & - \text { - MCF-7 (unstained) } \\
& - \text { - MCF-7/KCR (unstained) } \\
& - \text { - MCF-7 } \\
& \text { - MCF-7/KCR } \\
& -
\end{aligned}
$$

b
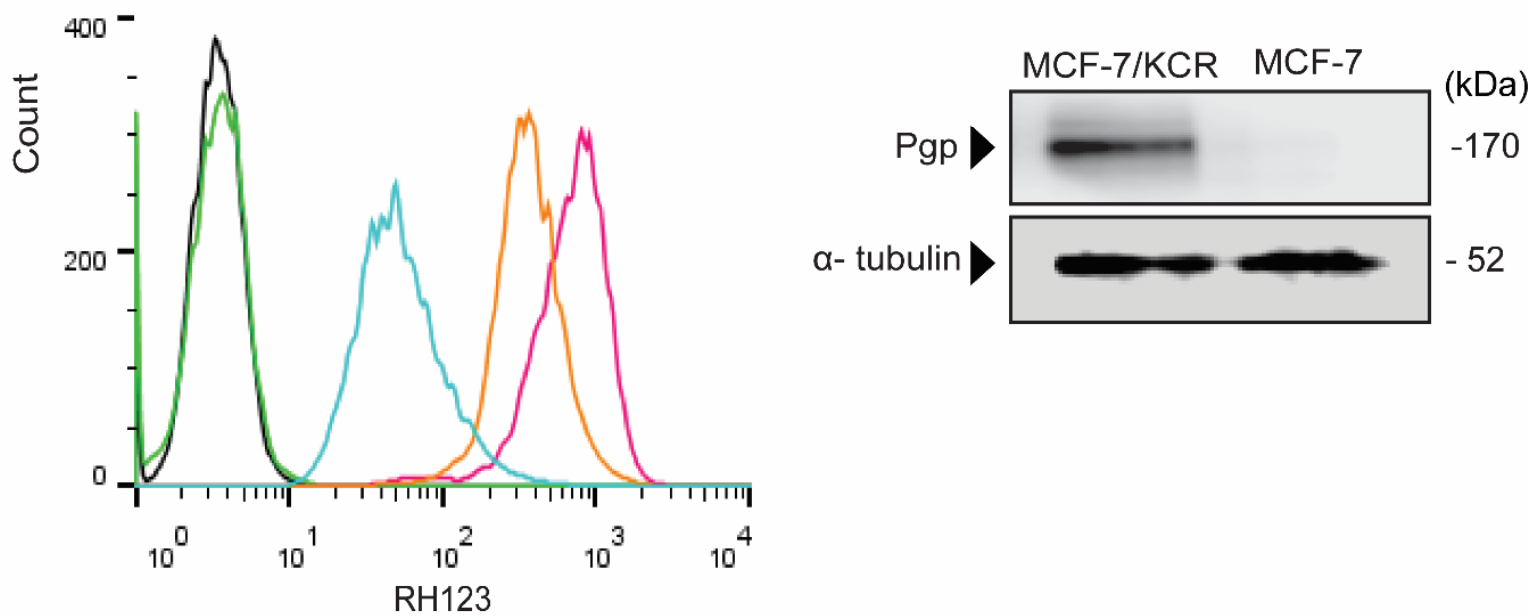

Figure 5: Characterization of multidrug-resistant MCF-7/KCR cells. (a) Histogram of Rhodamine 123 (RH123) retention in MCF-7 and MCF-7/KCR cells. (b) Representative Western blot of Pglycoprotein levels in MCF-7 and MCF-7/KCR cells. 


\subsection{Silver nanoparticles induce size-dependent cytotoxicity in breast cancer cells}

In order to verify the cytotoxic potential of both sized AgNPs on MCF-7 and MCF-7/KCR cells, we performed MTT viability assay with various concentrations of AgNPs for 24 and 48h. The $\mathrm{IC}_{50}$ values (Table 6) obtained from MTT cell viability assay data indicated that toxicity depended on the nanoparticle size, on the length of the treatment time, as well as on the cell type.

Table 6: Table of $\mathrm{IC}_{50}$ values calculated from MTT assay

\begin{tabular}{l|cccc}
\hline & \multicolumn{2}{c}{ 24 HOURS } & \multicolumn{2}{c}{ 48 HOURS } \\
\hline & $5 \mathrm{~nm} \mathrm{AgNP}$ & $75 \mathrm{~nm} \mathrm{AgNP}(\mu \mathrm{M})$ & $5 \mathrm{~nm}$ AgNP & $75 \mathrm{~nm}$ AgNP \\
\hline MCF-7 & $212 \pm 1.0$ & $284.2 \pm 1.1$ & $179.4 \pm 1.0$ & $222.2 \pm 1.1$ \\
\hline MCF-7/KCR & $244.1 \pm 1.0$ & $414.7 \pm 1.2$ & $232.9 \pm 1.1$ & $259.9 \pm 1.1$ \\
\hline
\end{tabular}

In agreement with previously reported observations (M. V. D. Z. Park et al. 2011; Miethling-Graff et al. 2014) drug-resistant cells showed more resistance to AgNP-induced cytotoxicity than their drug sensitive counterparts. This result is not surprising since drugresistant cells develop efficient cellular stress management mechanisms. As it is shown in Table 6., $5 \mathrm{~nm}$ AgNPs were more cytotoxic than $75 \mathrm{~nm}$ AgNPs to both MCF-7 and MCF$7 / \mathrm{KCR}$ cells. Naturally, $48 \mathrm{~h}$ treatment resulted in higher degree of cell death indicated by decreased $\mathrm{IC}_{50}$ values of respective treatments. Largest difference in $\mathrm{IC}_{50}$ between 24 and $48 \mathrm{~h}$ treatments (414.7 \pm 1.2 and 259.9 \pm 1.1 respectively) was observed in MCF-7/KCR cells treated with $75 \mathrm{~nm}$ AgNPs. 


\section{3. $\quad 75 \mathrm{~nm}$ AgNP treatment inhibits Pgp efflux activity but does not affect protein levels in drug-resistant cells.}

a

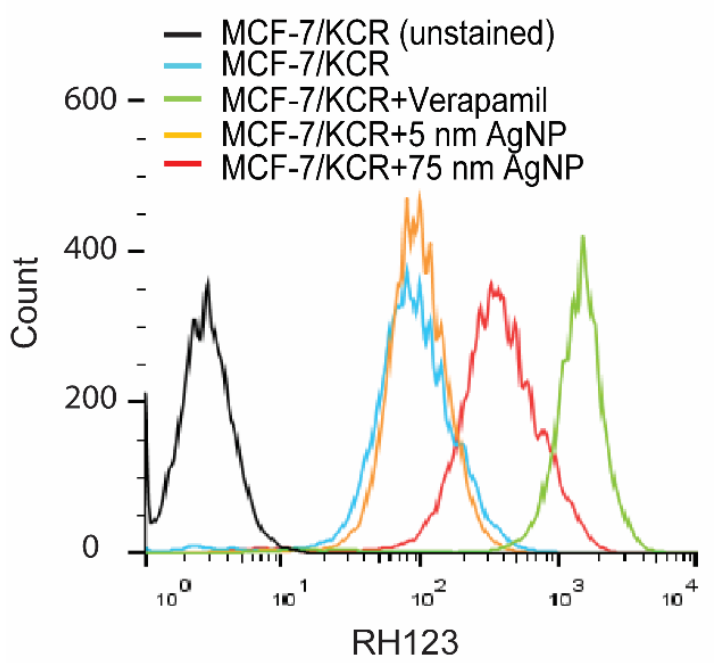

b

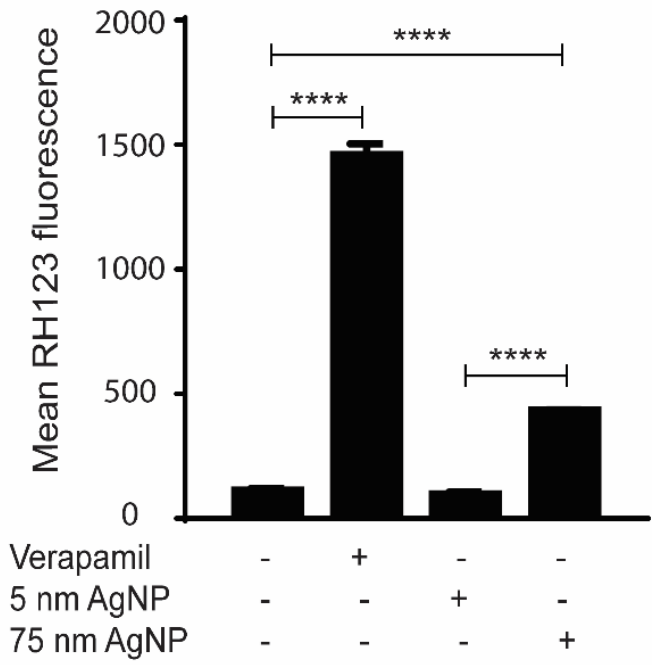

Figure 6: Rhodamine 123 efflux activity of drug-resistant MCF-7/KCR cells under AgNP treatment. (a) Histograms of Rhodamine 123 accumulation and (b) mean Rhodamine 123 fluorescence of verapamil-treated, $5 \mathrm{~nm}$ or $75 \mathrm{~nm}$ AgNP-treated MCF-7/KCR cells. Values are the means \pm standard deviations of three independent experiments $(* * * * \mathrm{P}<0.0001$, Fisher's LSD test)

We exposed MCF-7/KCR cells to $5 \mathrm{~nm}$ or to $75 \mathrm{~nm} \mathrm{AgNPs}$ and detected intracellular accumulation of RH123 by flow cytometry (Figure 6a, b). Administration of Pgp inhibitor verapamil resulted in elevated retention of RH123 in drug-resistant cells. Exposure of MCF7/KCR cells to $5 \mathrm{~nm}$ AgNPs showed intracellular RH123 fluorescence intensities comparable to control cells. Remarkably, administration of $75 \mathrm{~nm}$ AgNPs inhibited significantly the efflux activity of MCF-7/KCR cells (Figure $6 \mathrm{a}, \mathrm{b}$ ). These results certainly indicate that functional inactivation of Pgp efflux relies largely on nanoparticle size.

Biological effects of silver nanoparticles are highly dependent on their ability to internalize (Asharani et al., 2009). Therefore, we intended to verify their internalization potential by TEM analysis in MCF-7/KCR cells. For this purpose, AgNPs were applied on the drug-resistant MCF-7/KCR cells. 

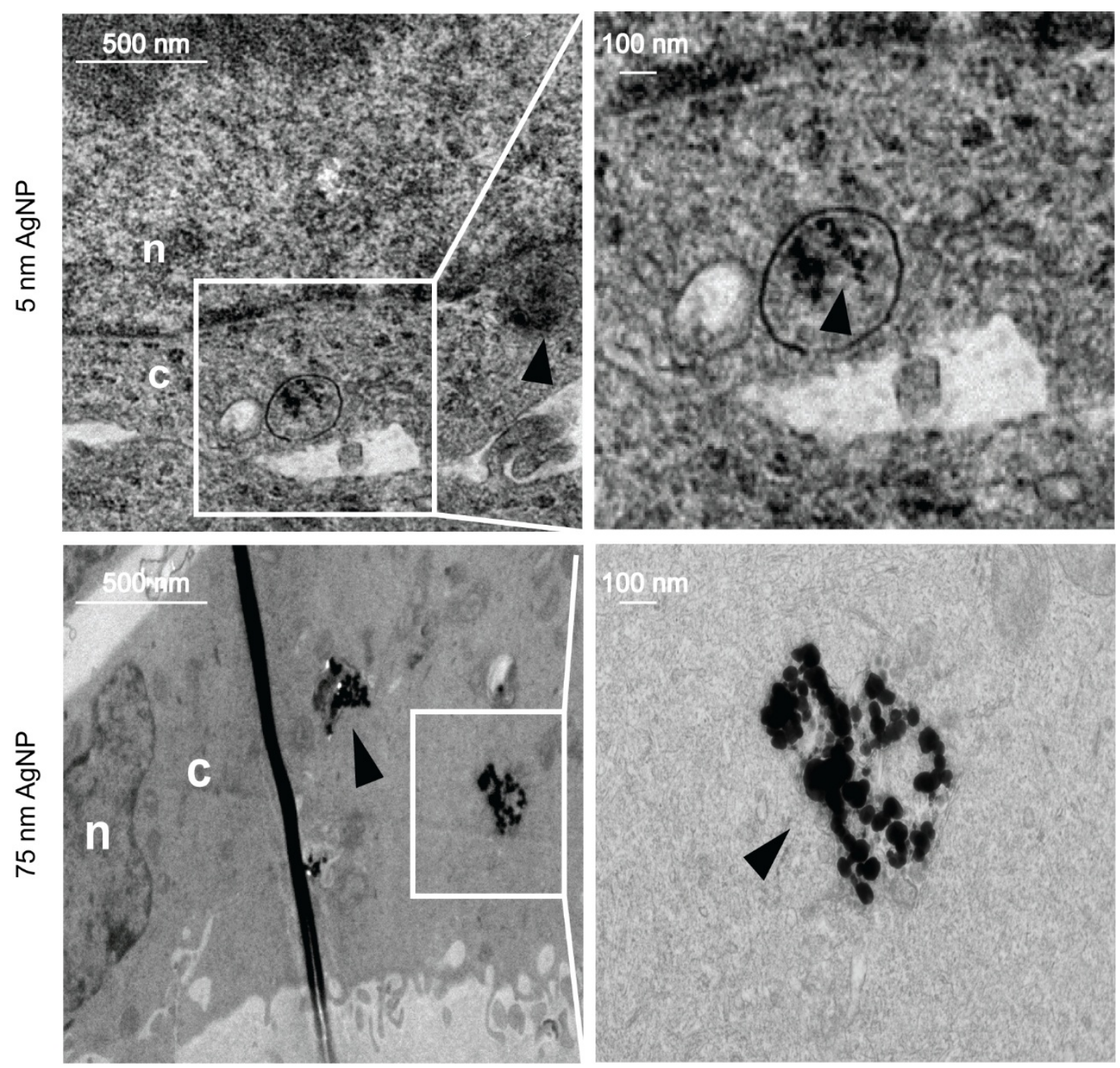

Figure 7: Silver nanoparticle internalization. Transmission electron microscopic images show internalization of AgNPs in drug-resistant MCF-7/ KCR cells.

The representative TEM micrographs (Figure 7) demonstrate the successful uptake of both sized silver nanoparticles by MCF-7/KCR cells. $5 \mathrm{~nm}$ particles were observed mainly in membrane-coated bodies while $75 \mathrm{~nm}$ AgNPs were found mainly in the cytoplasm of the cells. No AgNPs were found in nuclei, mitochondria or within the endoplasmic reticulum. 


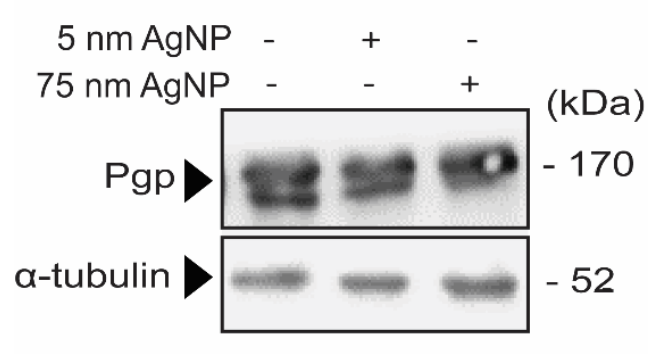

b

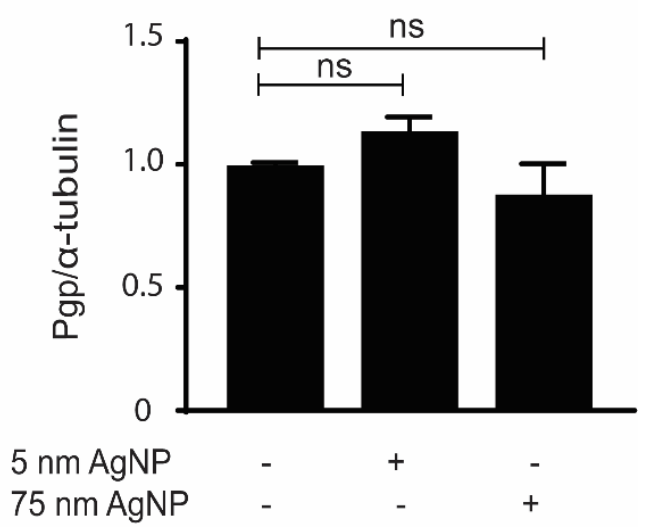

Figure 8: Pgp protein expression level in MCF-7/KCR cells after AgNP treatment. (a) Pgp protein levels in multidrug-resistant cells treated with $5 \mathrm{~nm}$ or $75 \mathrm{~nm}$ AgNPs determined by western blot. (b) Densitometric quantitation of Pgp western blots. Values are the means \pm standard deviations of three independent experiments (Fisher's LSD test).

Our group has previously reported (Kovács, et al., 2016) that treatment of MDR colon adenocarcinoma cells with $28 \mathrm{~nm}$ AgNPs led to downregulation of Pgp expression. With reference to this finding we hypothesized that a similar attenuation in Pgp protein expression may account for the inhibitory effect of AgNPs on Pgp efflux activity. Therefore, this premise was tested by analysing the Pgp protein levels of MCF-7/KCR cells treated with differently sized AgNPs. Surprisingly, we found no changes in Pgp protein levels of $5 \mathrm{~nm}$ or of $75 \mathrm{~nm}$ AgNP-treated cells compared to untreated counterparts (Figure 8a, b). Therefore, we concluded that the observed reduction in RH123 efflux following $75 \mathrm{~nm} \mathrm{AgNP}$ treatments is not coupled to attenuated Pgp protein expression in MCF-7/KCR cells. 


\subsection{Inhibition of Pgp by $75 \mathrm{~nm}$ AgNPs sensitizes drug-resistant cells to doxorubicin-induced apoptosis}
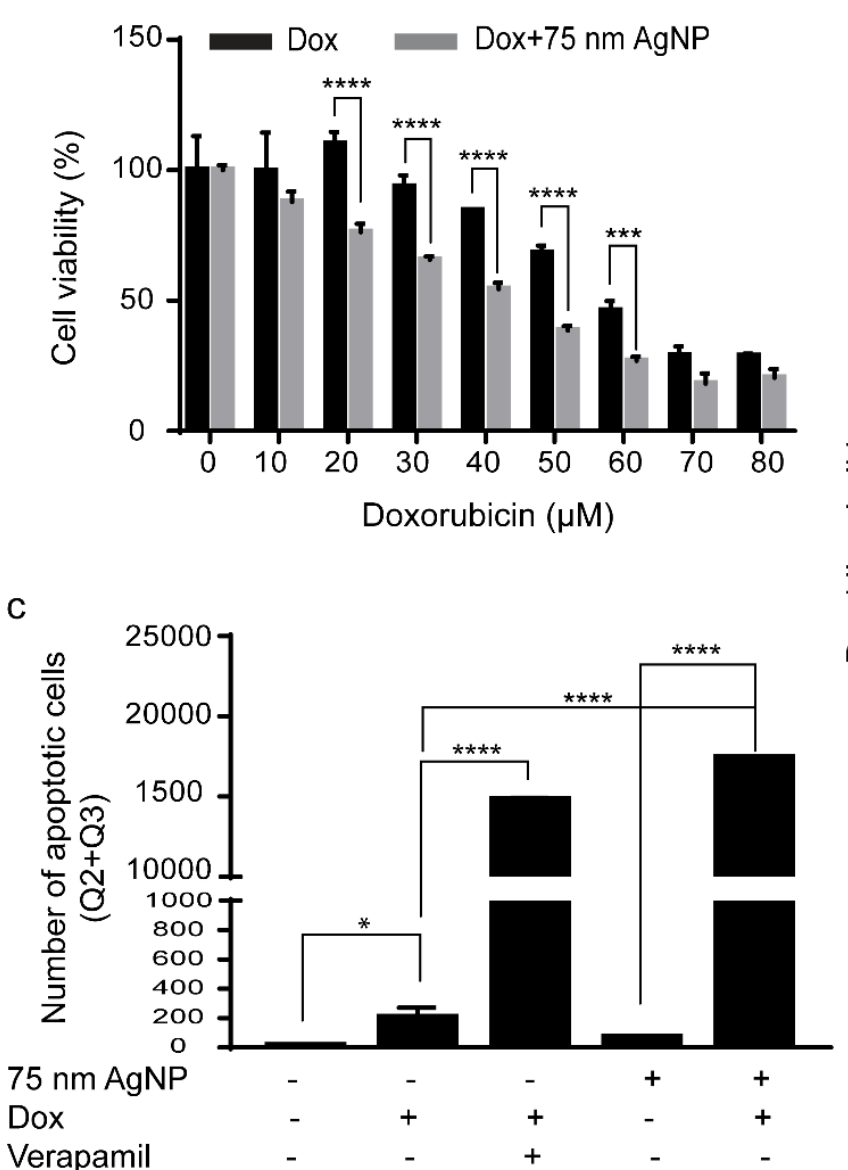

b

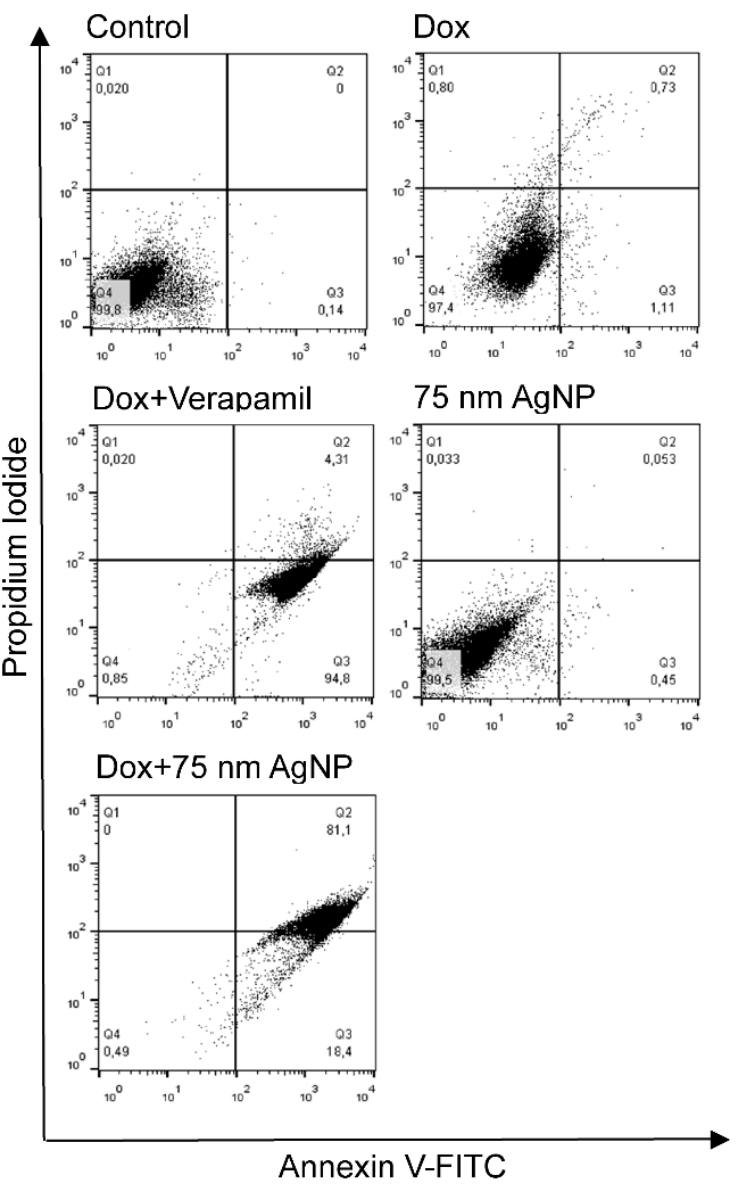

Figure 9: Sensitizing effect of $75 \mathbf{~ n m ~ A g N P s ~ t o ~ d o x o r u b i c i n - i n d u c e d ~ c e l l ~ d e a t h . ~ ( a ) ~ C y t o t o x i c i t y ~ o f ~}$ doxorubicin and of doxorubicin and $75 \mathrm{~nm}$ AgNP combination in MCF-7/KCR cells. (b) Representative dot plots of AnnexinV/PI staining, and (c) number of apoptotic drug-resistant cancer cells following 75 nm AgNP and/or doxorubicin treatment or verapamil administration. The values are the means \pm standard deviations of three independent experiments $(* \mathrm{P}<0.03 * * * * \mathrm{P}<0.0001$, Fisher's LSD test)

$\mathrm{MCF}-7 / \mathrm{KCR}$ is an in vitro drug resistance model, which was developed to resist cytotoxic effects of doxorubicin at high doses (Kars et al. 2006). As 75 nm AgNPs inhibited Pgp efflux activity, this treatment should also sensitize MCF-7/KCR cells to doxorubicin-induced killing. To test this idea MCF-7/KCR cells were seeded at $10^{4}$ cells/well in a 96 well plate. Next day, cells were treated with $150 \mu \mathrm{M}$ of $75 \mathrm{~nm}$ AgNPs. After 48 hours, the medium was replaced by a medium containing $150 \mu \mathrm{M}$ of $75 \mathrm{~nm}$ AgNPs and doxorubicin at various concentrations and were incubated for further 24 hours. Following treatments MTT assays were performed and results were compared to cytotoxicity in MCF-7/KCR cells receiving similar concentration 
range of doxorubicin alone for $24 \mathrm{hrs}$. Our results (Figure 9a) indicate that after co-treatments with AgNPs doxorubicin cytotoxicity is significantly higher compared to that observed for cells receiving doxorubicin treatment alone.

To examine whether the observed cytotoxicity upon $75 \mathrm{~nm}$ AgNP + doxorubicin administrations is the result of apoptosis, MCF-7/KCR cells were seeded at $2 \times 10^{6}$ cells/well density in 6-well plates. On the following day cells were treated with $75 \mathrm{~nm}$ AgNPs at $150 \mu \mathrm{M}$ concentration for 48 hours. After 48 hours, the medium was replaced with a medium containing $150 \mu \mathrm{M}$ of $75 \mathrm{~nm} \mathrm{AgNPs}$ and $20 \mu \mathrm{M}$ doxorubicin and cells were incubated for further 24 hours. A combination of the Pgp blocker verapamil at $4 \mu \mathrm{M}$ and doxorubicin at $20 \mu \mathrm{M}$ was applied as a positive control for $24 \mathrm{~h}$ to assess the apoptotic effect of doxorubicin in MCF-7/KCR cells. After the treatments, cells were collected and stained with AnnexinV-FITC/PI followed by flow cytometry. The number of apoptotic cells calculated from representative dot plots (Figure $9 \mathrm{~b}, \mathrm{c})$ indicated that doxorubicin treatment alone in this concentration induced only slight apoptosis, which was drastically enhanced when this drug was given in combination with 75 nm AgNPs. Although we have not observed higher Pgp inhibition by $75 \mathrm{~nm}$ AgNPs compared to verapamil (Figure 6), the magnitude of apoptosis induction in this combinational treatment is equivalent to that of verapamil treatment. This disparity can be explained by the fact that the response to a drug is exponential to its dose only until a certain extent and any further increase in dose fails to improve the response, thus yielding a typical S-shaped dose-response curve. Therefore, elevated intracellular drug amounts will not lead to a corollary elevation in its effects. Our results verify that $75 \mathrm{~nm}$ AgNPs sensitize drug-resistant MCF-7/KCR cells to doxorubicin-induced apoptosis. Nevertheless, these experiments do not reveal whether the induced apoptosis is caspase-dependent or independent. Since MCF-7 cells do not express functional caspase 3 (Jänicke 2009), which is a key executioner caspase, the involvement of caspase 3 in the mechanism of the induced apoptosis can be ruled out. However, the involvement of other caspases such as caspase 6,7 and 9 in the execution of apoptosis without caspase 3 in MCF-7 cells (Liang et al., 2001) cannot be dismissed. 


\subsection{AgNPs induce oxidative stress and mitochondrial damage}

a
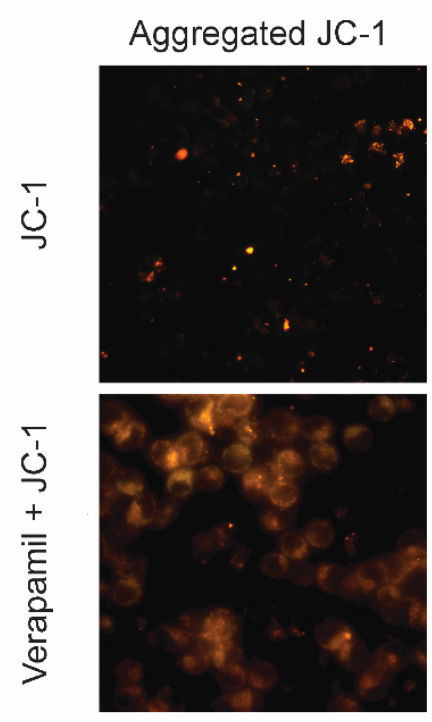

C

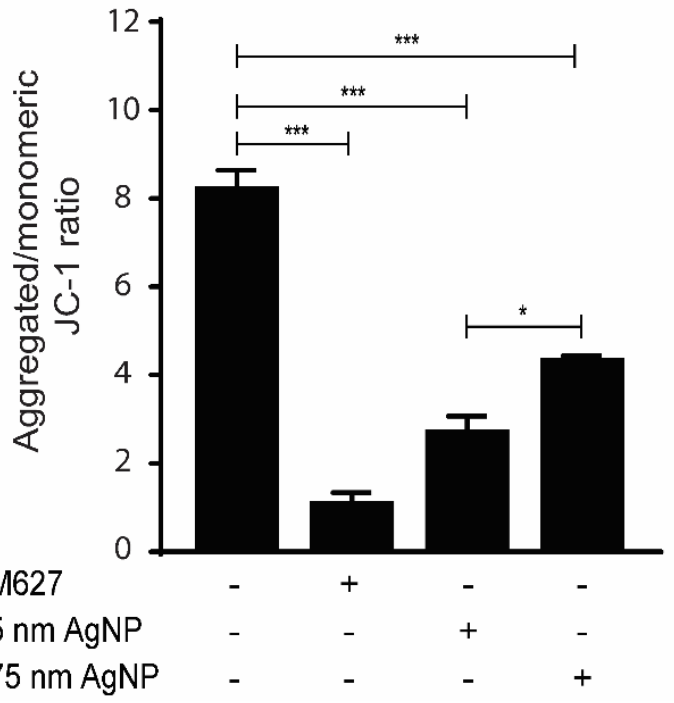

b

Monomeric JC-1
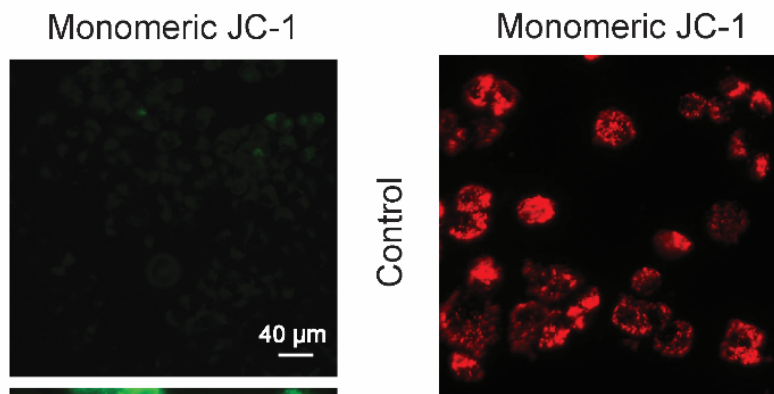

Aggregated JC-1
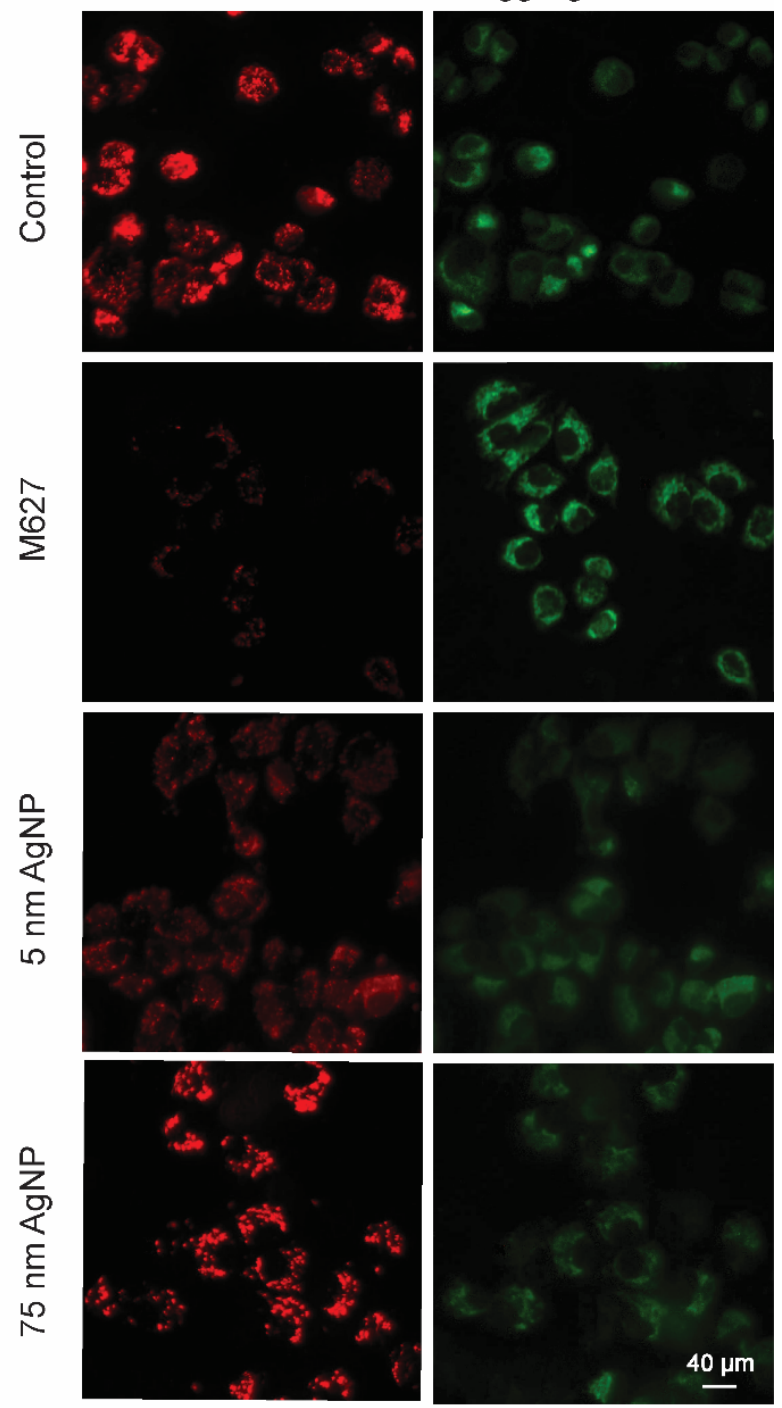

Figure 10: AgNPs induce mitochondrial damage in MCF-7/KCR cells. (a) Fluorescence microscopic images of drug-resistant MCF-7/KCR cells loaded with JC-1 dye without and with verapamil pre-treatment. (b) Representative image of $5 \mathrm{~nm} \mathrm{AgNP-,} 75 \mathrm{~nm} \mathrm{AgNP-}$, or the apoptosis inducer M627-treated MCF-7/KCR cells after JC-1 staining. JC-1 aggregates show red and JC-1 monomers green fluorescence. (c) Aggregated-to-monomeric JC-1 ratio (red-to-green fluorescence ratio) was determined by image analysis. Values are the means \pm standard deviations of three independent experiments $(* \mathrm{P}<0.03 * * * \mathrm{P}<0.0002$, Fisher's LSD test)

Inhibition of Pgp efflux activity by $75 \mathrm{~nm}$ AgNP treatment, without compromising the Pgp expression was quite intriguing, which prompted us to investigate the underlying cellular mechanisms. As a member of $\mathrm{ABC}$ transporters, Pgp-mediated drug transport against a 
concentration gradient is an energy-driven process fuelled by ATP hydrolysis. As cellular power houses, mitochondria generate the majority of ATP. Based on this we hypothesized that as AgNPs can induce mitochondrial damage (Ma et al. 2015), this might result in lowered cellular ATP amount, which may ultimately lead to a compromised export of substrates from drug-resistant cancer cells. A similar feature of a novel compound RY10-4 was reported, as its Pgp inhibitory potential was partially attributed to its cellular ATP diminishing capacity (Xue et al., 2014).

To examine whether the functional integrity of mitochondria is maintained upon AgNP treatments, we performed JC-1 staining. MCF-7/KCR cells were treated with $5 \mathrm{~nm}$ or $75 \mathrm{~nm}$ AgNPs or with the apoptosis inducer M627. Since, JC-1 is a substrate of Pgp, cells were treated with verapamil prior to JC-1 loading. Figure 10a shows differences in JC-1 retention before and after verapamil treatment in MCF-7/KCR cells and verifies the application of verapamil before JC-1 staining. M627 treatment induced significant mitochondrial damage implied by decreased amount of JC-1 aggregates (red fluorescence) and increased JC-1 monomers (green fluorescence) compared to control cells (Figure 10b, c), leading to the lowest calculated redto-green fluorescence ratio. Both sized AgNPs manifested destructive capacity towards mitochondria inferred by reduced red-to-green fluorescence ratio compared to control samples (Figure 10b, c). It is noteworthy, that according to our results $5 \mathrm{~nm}$ AgNPs were significantly more detrimental to mitochondria than $75 \mathrm{~nm}$ counterparts.

a

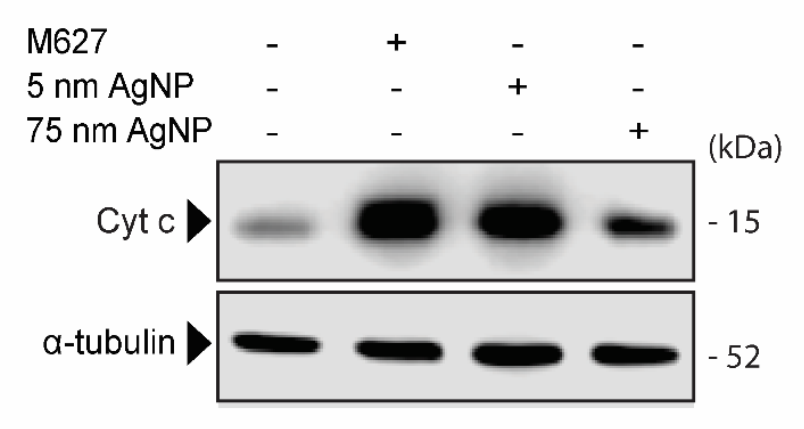

b

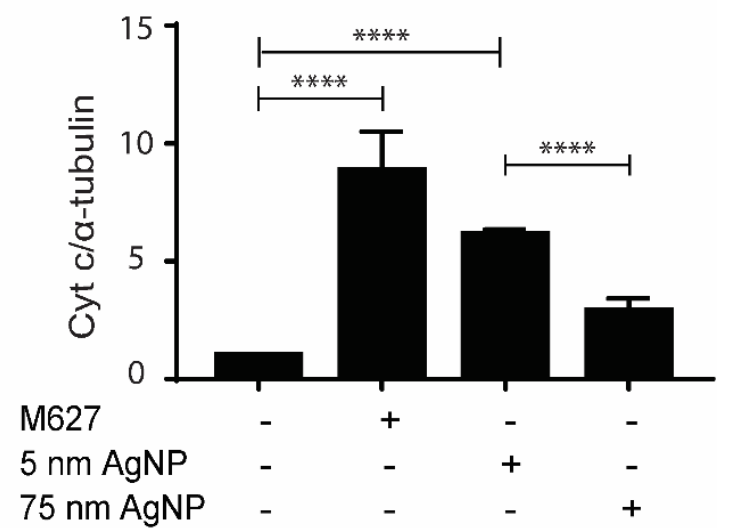

Figure 11: Cytoplasmic cytochrome c protein level in AgNP-treated MCF-7/KCR cells. Western blot of cytochrome c in MCF-7/KCR cells after $5 \mathrm{~nm}, 75 \mathrm{~nm}$ AgNP or M627 treatments. (b) Densitometric quantitation of Cyt $\mathrm{c}$ western blots. Values are the means \pm standard deviations of three independent experiments ( $* * * * \mathrm{P}<0.0001$, Fisher's LSD test) 
Cytochrome c (Cyt c) is a key component in mitochondrial electron transport chain. It is normally residing in the inner mitochondrial membrane and is released into cytoplasm during mitochondrial damage (Ott et al., 2002). Cyt c binds with Apafl in the cytoplasm to initiate apoptosis (Cai et al., 1998). Therefore, cytoplasmic localization of Cyt c further strengthens the evidence of mitochondrial damage and of apoptosis. In agreement with JC-1 results, treatments with either AgNPs resulted in mitochondrial damage verified by the release of cytochrome $\mathrm{c}$ into the cytoplasm of MCF-7/KCR cells (Figure 11a, b). However, we found that exposure to $5 \mathrm{~nm}$ AgNPs had a more pronounced effect compared to $75 \mathrm{~nm}$ AgNPs, since smaller nanoparticles caused a similar impact as it was observed following M627 administration (Figure 11a, b).

Internalized AgNPs release silver ions (Cortese-Krott et al., 2009; Shim et al., 2017). Silver ions are potent inducers of oxidative stress, which is strongly coupled to mitochondrial dysfunction (Kowaltowski et al., 2001). Additionally, silver ions can also cause direct mitochondrial damage and denaturation of proteins (Xu et al., 2019). Therefore, we investigated the ROS generating potential of our AgNP samples.

a

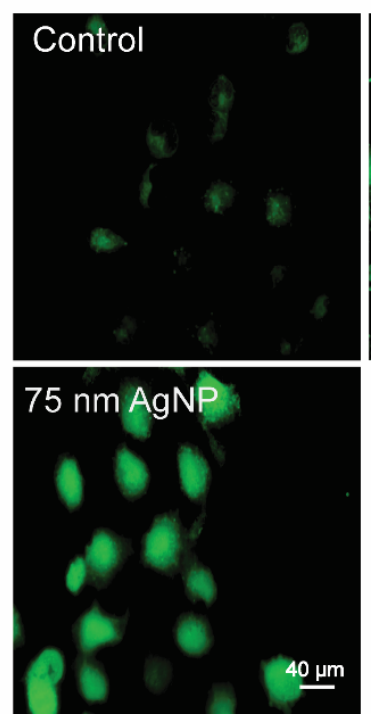

b
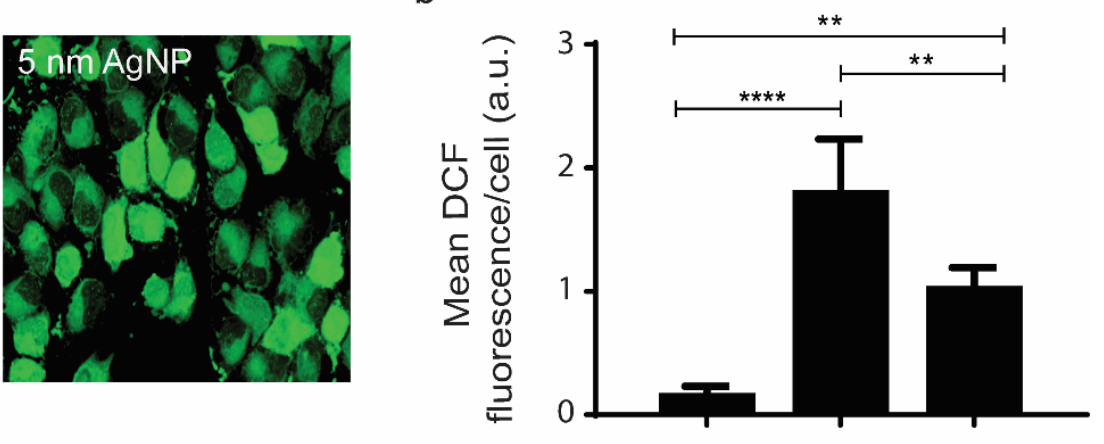

$5 \mathrm{~nm} \mathrm{AgNP}$ $75 \mathrm{~nm}$ AgNP

Figure 12: AgNPs induce ROS generation in MCF-7/KCR cells. (a) Fluorescence microscopic images of DCFDA-stained, AgNP-treated MCF-7/KCR cells. (b) Mean DCF fluorescence intensity determined by image analysis. Values represent the mean \pm standard deviation calculated from 25 cells from two independent experiments $(* * \mathrm{P}<0.002 * * * * \mathrm{P}<0.0001$, Fisher's LSD test) 
MCF-7/KCR cells were treated with $150 \mu \mathrm{M}$ of $5 \mathrm{~nm}$ and $75 \mathrm{~nm} \mathrm{AgNPs}$ for $48 \mathrm{hrs}$ and stained with DCFDA. Representative images and mean fluorescence intensity values (Figure 12a, b) show that both sized AgNPs induce significant ROS production compared to untreated control, however, $5 \mathrm{~nm}$ AgNPs are more potent in this respect than $75 \mathrm{~nm}$ AgNPs. Nevertheless, it is not clear whether silver ions cause the observed mitochondrial damage directly or it is mediated through ROS generation. These evidences collectively prove the point that mitochondrial damage triggered by $75 \mathrm{~nm}$ AgNPs is not the underlying cause of its Pgp inhibitory action in MCF-7/KCR cells because $5 \mathrm{~nm}$ AgNPs exhibit higher mitochondrial destructive potential than $75 \mathrm{~nm}$ AgNPs.

\section{6. $75 \mathrm{~nm}$ AgNP treatments cause depletion of ER calcium stores and ER stress}

Endoplasmic reticulum (ER) is the primary site of protein assembly and homeostasis especially of glycoproteins. The highly reductive and calcium rich ER lumen ensures continuous functioning of ER protein quality control mechanisms, like the calnexin/calreticulin cycle. Calnexin and calreticulin are ER resident calcium binding lectins which ensure the precise folding and oligomerization of glycoproteins in the ER (Araki et al., 2012; Rutkevich et al., 2011;Williams et al., 2006). Perturbance in its homeostasis triggers ER stress which further disturbs the protein folding machinery and leads to the activation of the evolutionarily conserved unfolded protein response (UPR) and ER-associated degradation (ERAD) (Araki et al, 2012; Rutkevich et al., 2011; Wang et al., 2003).

AgNPs are reported to have the ability to induce ER stress and disturb cellular calcium homeostasis (Asharani et al., 2009; Zhang et al., 2012). Therefore, we examined whether AgNPs can induce ER stress and activate unfolded protein response (UPR) in drug resistant cancer cells. MCF-7/KCR cells were treated with $5 \mathrm{~nm}$ or $75 \mathrm{~nm}$ AgNPs or received ER stressinducing dithiothreitol (DTT) treatment as a positive control. Using RT-qPCR and western blots we verified transcriptional (Figure 13a) and translational (Figure 13b, c) elevation of ER stress markers such as resident ER chaperones Grp94 and Grp78/Bip, as well as of the ER stress-provoked pro-apoptotic mediator GADD153. Although results indicate a significant transcriptional elevation of all the three ER stress markers, only GADD153 manifested an elevated amount of the translated product. This discrepancy is not so surprising as MCF-7 cells have deregulated UPR, therefore, have high basal levels of GRP94 and GRP78 (Gazit et al., 1999), hence further increases in their protein levels are not always possible during ER stress. 
a

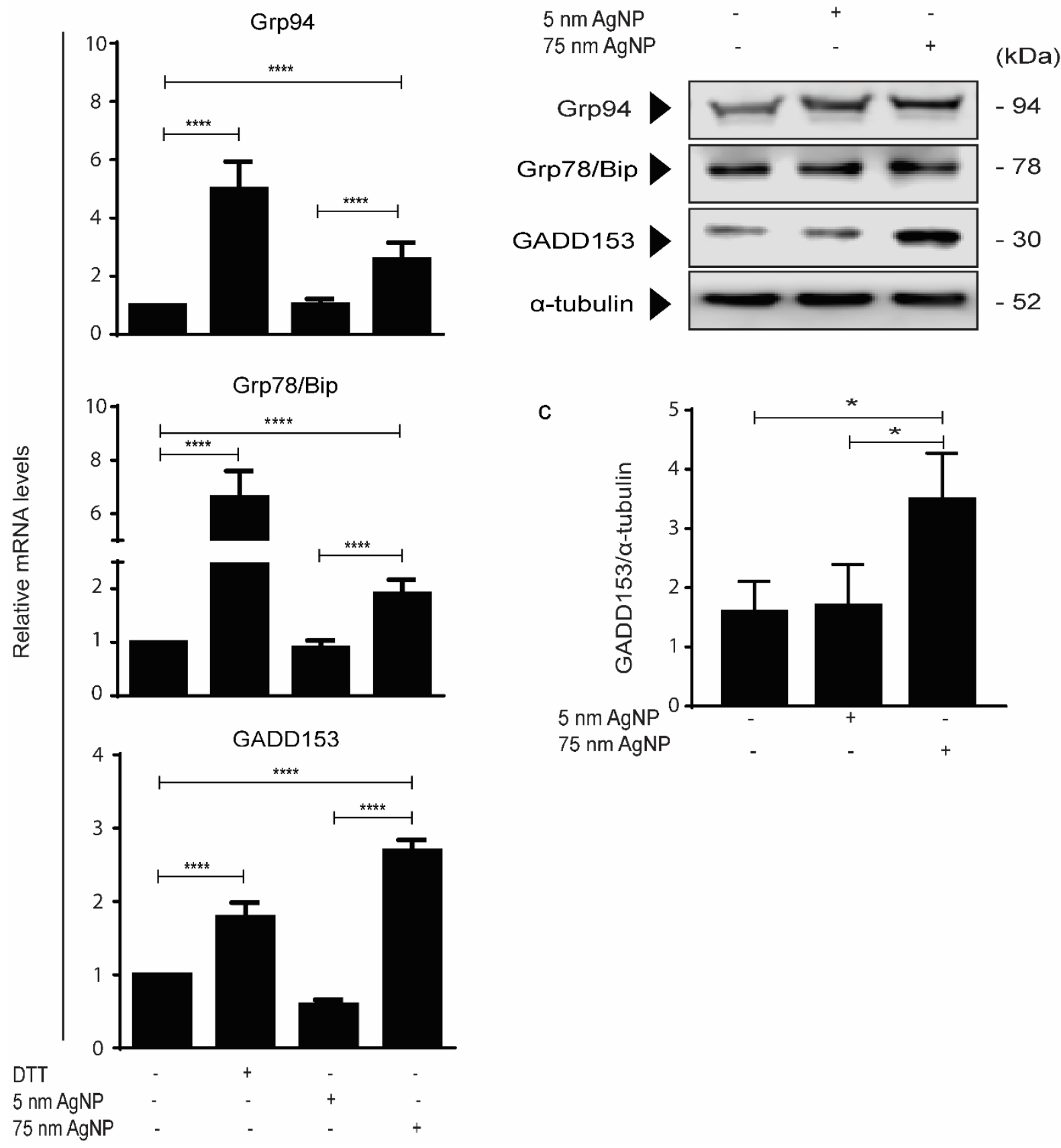

Figure 13: 75 nm AgNP treatment leads to ER stress. (a) Relative mRNA levels of ER stress markers in MCF-7/KCR cells treated with $5 \mathrm{~nm}$ or $75 \mathrm{~nm}$ AgNPs or with the ER stress inducer DTT. (b)Protein levels of ER stress markers detected by immunoblot. (c) Densitometric quantitation of GADD153 protein levels. The values represent the mean \pm standard deviation calculated from three independent samples $(* \mathrm{P}<0.03 * * * * \mathrm{P}<0.0001$, Fisher's LSD test).

ER stress activates autophagy in order to clear out aberrantly folded protein burden (Rashid et al., 2015). Hence, autophagy activation provides a further strong evidence for ER stress 
induction. Therefore, we examined autophagy activation in MCF-7/KCR cells following $5 \mathrm{~nm}$ and $75 \mathrm{~nm}$ AgNP treatments.

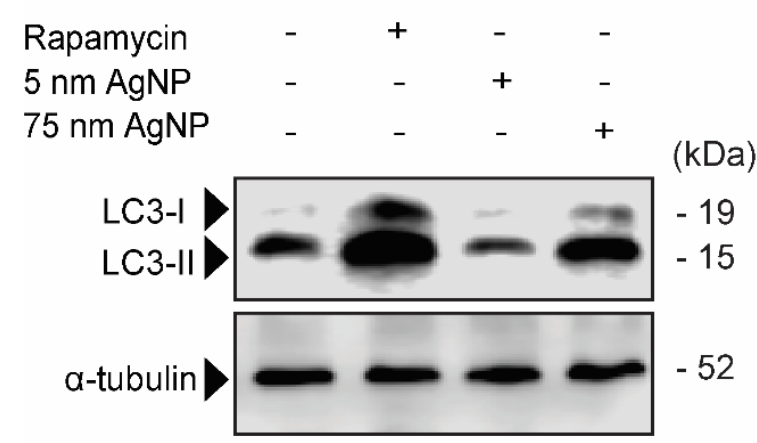

b

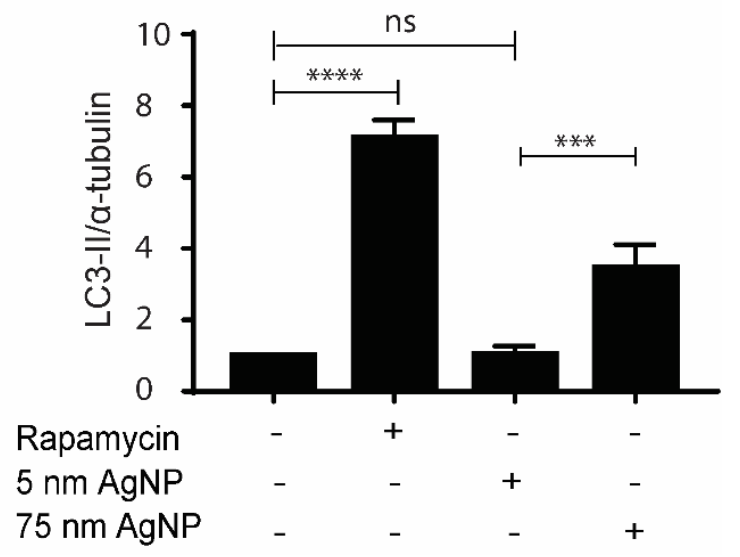

Figure 14: 75 nm AgNPs induce autophagy. Representative western blots show changes in LC3-I and LC3-II levels following 48-hour treatments with $5 \mathrm{~nm}, 75 \mathrm{~nm}$ AgNPs or with Rapamycin. (b) Densitometric quantitation of LC3-II western blots. Values are the means \pm standard deviations of three independent experiments $(* * * \mathrm{P}<0.0002 * * * * \mathrm{P}<0.0001$, Fisher's LSD test)

MCF-7/KCR cells were treated with either $5 \mathrm{~nm}$ or $75 \mathrm{~nm}$ AgNPs or Rapamycin (positive control). We checked the amount of autophagy marker LC3 through western blot. Treatments with $5 \mathrm{~nm}$ AgNPs did not induce autophagy as the protein levels of LC3-I and LC3-II were comparable to those of the untreated control cells (Figure 14a, b). On the other hand, $75 \mathrm{~nm}$ AgNPs triggered autophagy in drug-resistant MCF-7/KCR cells to a significantly higher extent than what was observed in untreated control and in $5 \mathrm{~nm}$ AgNP-exposed adenocarcinoma cells. We concluded that the capacity of autophagy induction in Pgp overexpressing drug-resistant MCF-7/KCR cells depends on the nanoparticle size, where $75 \mathrm{~nm}$ AgNPs trigger autophagy, however, $5 \mathrm{~nm}$ AgNPs do not.

Depleted ER calcium is a frequent cause of ER stress (Xu et al., 2005), therefore we headed to measure calcium release from ER with an external chemical stimulus using carbachol, which molecule stimulates $\mathrm{IP}_{3}$ receptors to release ER-stored calcium. This is based on the premise that if AgNP treatment leads to ER calcium depletion, an exposure to carbachol would result little or no calcium release into the cytoplasm compared to control cells with unstressed ER. Calcium released into the cytoplasm is immediately sensed by the pre-loaded calcium binding fluorescent dye Fluo-4, which enables real-time detection of calcium flux. In order to verify this calcium flux, control and $75 \mathrm{~nm}$ AgNP-treated MCF-7/KCR cells were first loaded with 
Fluo-4 and exposed to $100 \mu \mathrm{M}$ carbachol. Calcium flux was measured from at least 5 predefined region of interests (ROIs). As Fluo-4 is a substrate of Pgp, we pre-treated the samples with the Pgp inhibitor quinidine (this time not with verapamil, as it may influence calcium flux) before measurements.

a

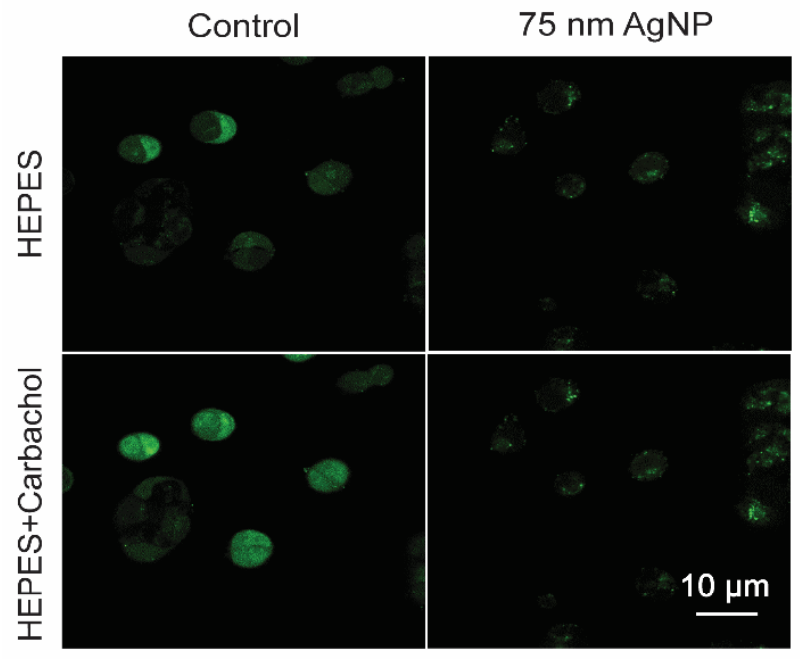

C

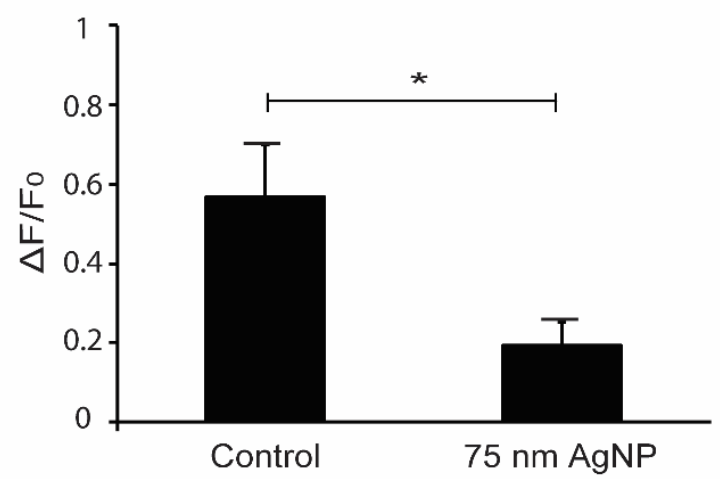

b

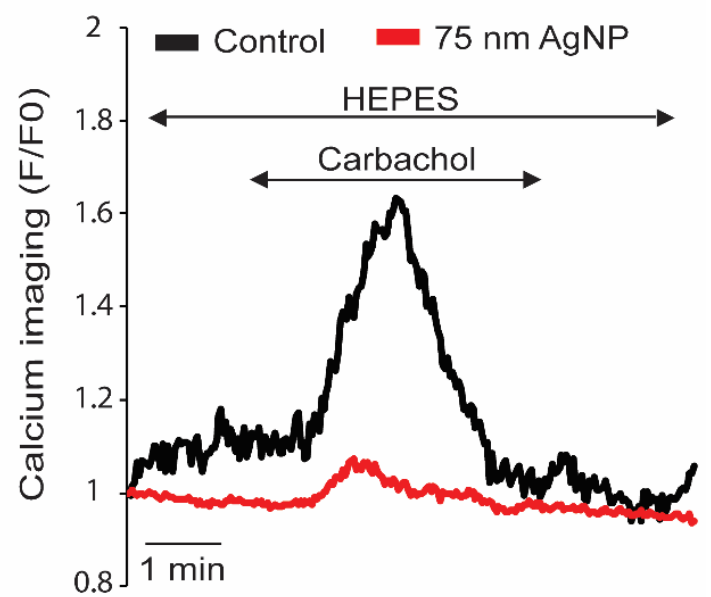

Figure 15: 75 nm AgNP treatment depletes ER calcium stores. (a) Fluorescent calcium imaging of untreated and $75 \mathrm{~nm}$ AgNPs-treated MCF-7/KCR cells upon carbachol administration. Pictures were taken before and 1 min after carbachol exposure. (b) Histogram of real-time calcium imaging from at least 5 ROIs (Region of interest) and (c) Representative bar graph of cytoplasmic calcium released on carbachol exposure. The values represent the mean \pm standard deviation calculated from three independent experiments ( $* \mathrm{P}<0.03$, Fisher's LSD test)

Fluorescent microscopic images and the associated histogram generated from real-time calcium release measurements prove that MCF-7/KCR cells treated with $75 \mathrm{~nm}$ AgNPs failed to respond to carbachol, indicating that ER calcium stores are already critically depleted or are 
below the detectable concentration in Pgp-overexpressing drug-resistant cancer cells treated with $75 \mathrm{~nm}$ AgNPs (Figure 15a-c).

These experimental results conclude that $75 \mathrm{~nm}$ AgNPs, but not $5 \mathrm{~nm}$ AgNPs induce ER stress in MCF-7/KCR cells. Although, it is yet not clear whether ER calcium loss is leading to ER stress or ER stress (due to other factors) is leading to calcium loss. Nevertheless, the present experimental results prove that treatment of drug-resistant cells with $75 \mathrm{~nm}$ AgNPs depletes ER calcium levels (Figure 15a-c), which is the probable reason for ER stress induction.

\subsection{5 nm AgNPs disrupt cellular Pgp distribution}

Unfavourable overloading of unfolded/misfolded proteins represent the primary consequence of ER stress, where cells find a solution in activating ER-associated protein degradation (ERAD) wired through UPR. ER degradation enhancing $\alpha$-mannosidase-like protein (EDEM) is an important candidate in transporting glycoproteins to degradation machinery that have failed through several futile attempts of calnexin/calreticulin cycles to impart proper folding (Wang et al., 2003). Therefore, transcriptional and/or translational activation of EDEM indicates ERAD activation (Wang et al., 2003; Xu et al., 2005). Under such circumstances a reduction in the total Pgp levels is expected. However, our attempts to see EDEM activation through qPCR and western blot in MCF-7/KCR cells treated with $5 \mathrm{~nm}$ or $75 \mathrm{~nm} \mathrm{AgNPs,} \mathrm{or} \mathrm{with} \mathrm{ER} \mathrm{stress-inducing} \mathrm{DTT} \mathrm{(positive} \mathrm{control)} \mathrm{indicated} \mathrm{no} \mathrm{significant}$ elevation in the transcribed and translated product of EDEM with nanoparticle treatment but only upon DTT treatment (Figure 16a-c), suggesting that ERAD has not been activated in cells treated with AgNPs. This is in agreement with unattenuated Pgp protein levels observed in 75 nm AgNP-treated MCF-7/KCR cells (Figure 8a, b).

EDEM itself is a glycoprotein and processed by calnexin/calreticulin cycle to mature and transport improperly folded glycoproteins for degradation (Wang et al., 2003). At critically low ER calcium levels, accelerated substrate degradation is thwarted due to inability of EDEM to bind calnexin (Wang et al., 2003). Therefore, unfolded proteins do not enter the degradation machinery but accumulate intracellularly. Since it was clear from calcium release experiments (Figure 15a-c) that treatment with $75 \mathrm{~nm}$ AgNPs depleted critically the ER of calcium in MCF7/KCR cells, we hypothesized that $75 \mathrm{~nm}$ AgNP treatments might lead to accumulation of misfolded/ unfolded Pgp in the ER or in the cytoplasm or both. Hence, a reduced number of Pgp on the plasma membrane might be the reason behind the observed Pgp efflux inhibition upon $75 \mathrm{~nm}$ AgNP treatment. 


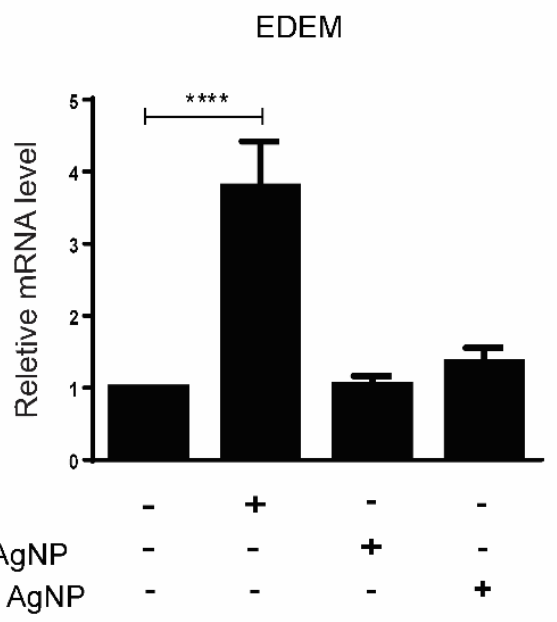

b

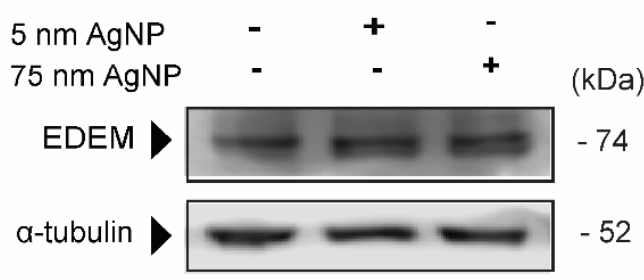

C

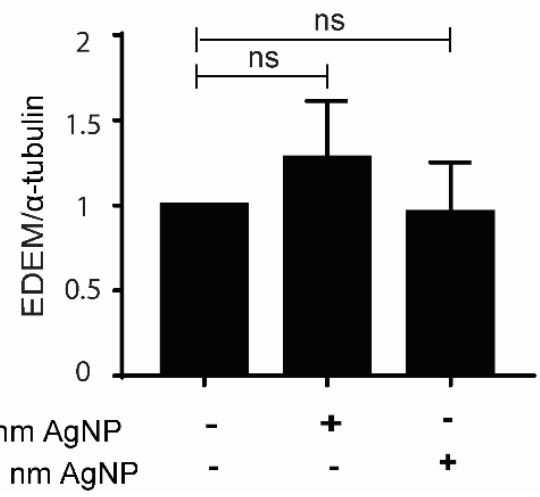

d

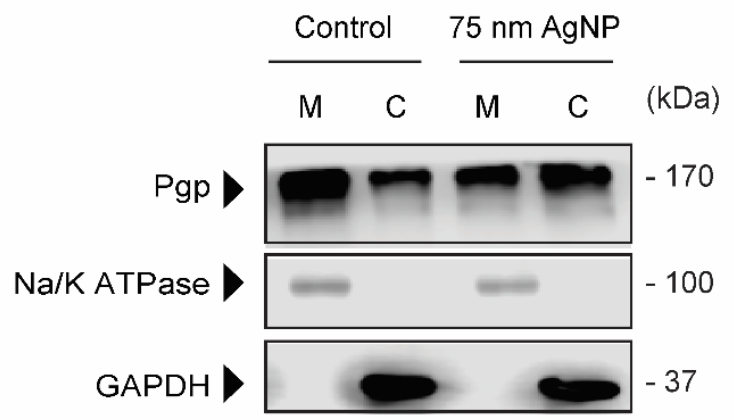

e
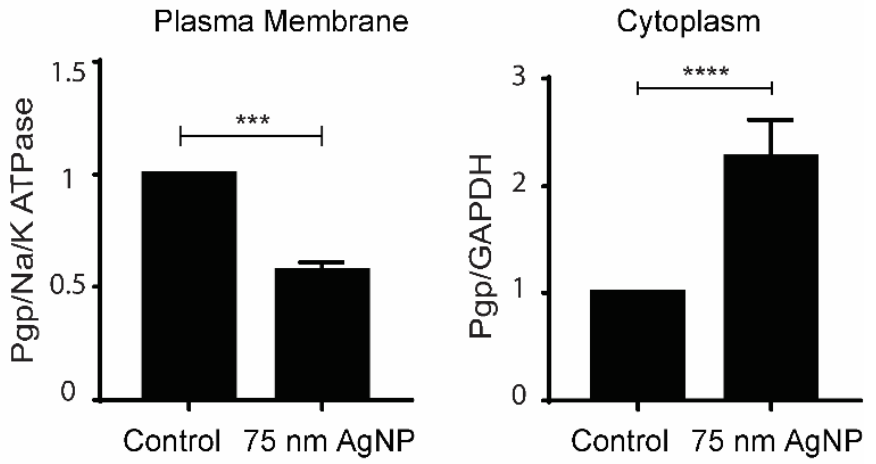

Figure 16: $75 \mathrm{~nm}$ AgNP treatment disrupts Pgp protein distribution between the plasma membrane and cytoplasm of MCF-7/KCR cells. (a) Relative mRNA and (b) protein levels of EDEM, a misfolded glycoprotein-binding protein in MCF-7/KCR cells treated with AgNPs. (c) Densitometric quantitation of EDEM western blots. (d) Pgp protein levels determined from the plasma membrane $(\mathrm{Na}+/ \mathrm{K}+$ ATPase-positive) and cytoplasmic fractions (GAPDH-positive) of control and $75 \mathrm{~nm}$ AgNPtreated MCF-7/KCR cells (M-Plasma membrane; C-Cytoplasm). (e) Densitometric quantitation of Pgp western blots. Values are the means \pm standard deviations of three independent experiments $(* * * \mathrm{P}<$ $0.0002 * * * * \mathrm{P}<0.0001$, Fisher's LSD test)

To strengthen this argument, we treated MCF-7/KCR cells with $75 \mathrm{~nm}$ AgNPs and determined the Pgp protein distribution between the plasma membrane and the cytoplasm. Plasma membrane and cytoplasmic fractions were verified for their purity by detecting $\mathrm{Na}^{+} / \mathrm{K}^{+}-$ ATPase and GAPDH, respectively. Our results indicate that the amount of Pgp in the plasma 
membrane (M) was lower and concomitantly, cytoplasmic fraction (C) of Pgp was higher after $75 \mathrm{~nm}$ AgNP treatment (Figure 16d, e). These data verify that the intracellular distribution of Pgp is disturbed by $75 \mathrm{~nm}$ AgNP treatment which explains the decreased Pgp transport activity without downregulating its expression. 


\section{DISCUSSION AND CONCLUSION}

Overexpression of the plasma membrane-localized ABC transporter P-glycoprotein (Pgp) is often the primary reason for the development of intrinsic or acquired multidrug resistance (MDR) in cancers (Gottesman et al., 2015). Pgp yields resistance by an efflux mechanism driven by ATP hydrolysis, where several structurally and functionally diverse chemotherapy drugs are exported from the cells without permitting to exert their cytotoxic activities (van Veen et al. 1998). Highly chemoresponsive solid tumors might turn multidrug-resistant due to extreme induction of Pgp expression and function (van Veen et al. 1998). Hence, inhibiting Pgp efflux activity is a long-standing goal in order to improve the efficacy of anti-neoplastic therapeutic strategies. In recent years in the clinical and experimental oncotherapy silver nanoparticles have obtained a special attention by virtue of their versatile biological properties (Avalos et al. 2014). In fact, our research group has also reported experimental data about silver nanoparticles of $28 \mathrm{~nm}$ size inhibiting Pgp activity and sensitizing multidrug-resistant colon cancer cells by downregulating Pgp expression both transcriptionally and translationally (Kovács et al., 2016). Based on these observations, our present study aimed to unravel the nanoparticle diameter-dependent Pgp inhibitory property of AgNPs in multidrug-resistant breast adenocarcinoma cells, relating this fundamental property of drug-resistant cancer cells to nanoparticle size as well as connecting it to the possible molecular mechanisms elicited by differently sized AgNPs to inhibit Pgp.

Treatments using AgNPs effectively killed MCF-7/KCR cells and the extent of AgNP induced cytotoxicity depended on their size, as $5 \mathrm{~nm}$ AgNPs were more toxic than $75 \mathrm{~nm}$ AgNPs (Table 6). Smaller sized AgNPs $(\leq 10 \mathrm{~nm})$ by releasing higher amount of silver ions due higher surface area usually exhibit higher cytotoxicity than larger AgNPs (Sriram et al. 2012). Reports from others also suggested higher cytotoxicity of smaller sized AgNPs $(\leq 10$ $\mathrm{nm}$ ) in vitro (Soares et al. 2016) and in vivo (Y. M. Cho et al. 2018) compared to larger sized $\operatorname{AgNPs}(\geq 50 \mathrm{~nm}$ ). Impressively, not only the cytotoxic potential but the Pgp efflux inhibiting propensity of AgNPs also proved to be dependent on nanoparticle size. However, regarding this feature, the $75 \mathrm{~nm}$ AgNPs, but not the $5 \mathrm{~nm}$ AgNPs were potent, since only larger nanoparticles inhibited Pgp efflux activity in drug-resistant MCF-7/KCR cells (Figure 6a, b) despite leaving the protein expression of Pgp unaffected (Figure 8a, b). This result emphasizes the fact that for efficiently interfering in Pgp action as well as obtaining the required degree of cytotoxicity, a proper AgNP size must be selected. Suitably sized AgNPs should be capable of 
reversing MDR in cancer cells and sensitize MDR cancer cells to the applied drugs. In order to verify this hypothesis, we co-treated MCF-7/KCR cells with $75 \mathrm{~nm} \mathrm{AgNPs} \mathrm{and} \mathrm{doxorubicin,}$ and found that the cytotoxicity and the apoptotic potency of doxorubicin, a Pgp substrate, applied usually to treat breast cancers, was significantly raised in the presence of $75 \mathrm{~nm}$ AgNPs (Figure 9a-c). This is an important finding, because MCF-7/KCR cells were developed on doxorubicin selection pressure, yet these cells are less resistant to doxorubicin when $75 \mathrm{~nm}$ AgNPs are co-administered with the drug doxorubicin. In previous investigations our group showed a similar drug sensitizing effect of effect AgNPs co-treated with several different chemotherapeutic agents in MDR Colo 320 colon adenocarcinoma cancer cells (Kovács et al., 2016).

As $75 \mathrm{~nm}$ AgNPs are quite large, they probably do not inhibit Pgp efflux by simple physical blockade or clogging, therefore other, presumably some indirect molecular and cellular mechanisms must be responsible for the observed inhibitory feature executed by these AgNPs. Our first idea was to test, whether elevated ROS production and the associated mitochondrial damage upon AgNP treatments (Carlson et al. 2008; Y. Xue et al. 2018) could lay in the background, since under such circumstances the ATP levels are diminished, which could result in decreased Pgp drug efflux activity. Our results demonstrated that $75 \mathrm{~nm}$ AgNPs were less potent inducers of ROS (Figure $12 \mathrm{a}, \mathrm{b}$ ) and could also damage mitochondria to a smaller extent (Figure 10b, c and 11a, b) than $5 \mathrm{~nm}$ AgNPs. Therefore, we concluded that ROS mediated mitochondrial dysfunction is not the underlying reason for reduced Pgp efflux function in drugresistant MCF-7/KCR cells treated with $75 \mathrm{~nm}$ AgNPs.

The endoplasmic reticulum is the principal location for protein folding and is a major site of cellular calcium storage. ER luminal calcium is essential for the undisturbed functioning of the ER protein folding machinery assisted by calnexin and calreticulin (D. B. Williams 2006). Moreover, the proper function of most ER chaperones is contingent on calcium availability. Perturbations of any kind such as glucose deficiency, depletion of ER calcium levels etc. cause disorder in ER protein homeostasis and would ultimately serve as signals for ER stress which in turn responds by activating unfolded protein response (UPR). The major consequences of ER stress are slower protein folding and reduced protein targeting (C. Xu et al., 2005). Hence, we hypothesized that by inducing ER stress in drug-resistant cells, $75 \mathrm{~nm}$ AgNPs might decrease the amount of Pgp reaching the plasma membrane, where it must exhibit its efflux function. Our work provided proofs of ER stress induction, as $75 \mathrm{~nm} \mathrm{AgNPs}$, but not $5 \mathrm{~nm}$ AgNPs triggered the expression of ER stress markers (Grp94, Grp78/Bip, GADD153) in MCF- 
7/KCR cells (Figure 13a-c). Furthermore, we showed evidence that the ER calcium stores were critically depleted when MCF-7/KCR cells were treated with $75 \mathrm{~nm}$ AgNPs (Figure 15a-c). These results are in agreement with previous research reports proving the ability of AgNPs to induce ER stress and disturb calcium homeostasis (Zhang et al. 2012; P V Asharani, Hande, and Valiyaveettil 2009). We further validated the involvement of ER stress underlying the observed Pgp inhibition by $75 \mathrm{~nm}$ AgNP by examining Pgp distribution between the plasma membrane and the cytoplasm of MCF-7/KCR cells. We found that plasma membrane Pgp levels were significantly decreased in MCF-7/KCR cells treated with $75 \mathrm{~nm}$ AgNPs, whereas Pgp levels in the cytoplasm increased (Figure 16d, e). This result was quite surprising because terminally mis-folded proteins are usually directed to proteasomal or autophagic degradation but do not accumulate in the cytoplasm. Along this line we examined and proved the activation of autophagy (He et al., 2009; Meusser et al., 2005) in MCF-7/KCR cells treated with $75 \mathrm{~nm}$ AgNPs (Figure 14a, b). Calnexin and calreticulin are ER-resident lectins, which bind native glycoproteins and make several attempts to ensure their proper folding before leaving the ER (Araki et al., 2012). Nevertheless, some proteins remain misfolded and are therefore destined to degradation with the help of EDEM (ER degradation-enhancing $\alpha$-mannosidase like protein), which plays a key role in transporting terminally misfolded glycoproteins to degradation. Therefore, EDEM upregulation under ER stress indicates successful streamlining of misfolded proteins from ER to the site of degradation (Wang et al., 2003). However, both EDEM upregulation and conveying the misfolded glycoproteins to degradation is impossible under conditions of critically low ER calcium levels, since EDEM is also a glycoprotein and requires the folding machinery of the ER for proper folding (Wang et al., 2003). Based on this information, and on our own results about calcium depletion of the ER (Figure 15a-c) we examined EDEM expression in MCF-7/KCR cells under $75 \mathrm{~nm}$ AgNP treatment. Our results prove that EDEM is not activated either transcriptionally or translationally under $75 \mathrm{~nm}$ AgNPs treatment (Figure 16a-c).

Our findings imply that intracellular Pgp distribution is disturbed and misfolded Pgp accumulates in the cytoplasm due to $75 \mathrm{~nm}$ AgNP-induced ER stress. This will ultimately lead to lower amounts of functioning Pgp transporters in the plasma membrane, thus to a reduced Pgp drug efflux. 
The key findings of the present study are that

- $75 \mathrm{~nm}$ AgNPs inhibit Pgp efflux activity and sensitize multidrug-resistant MCF-7/KCR cells to doxorubicin-induced apoptosis without causing significant changes in Pgp expression.

- AgNPs size-dependently induce oxidative stress, autophagy and mitochondrial damage in multidrug-resistant MCF-7/KCR cells.

- $75 \mathrm{~nm}$ AgNPs deplete ER calcium stores and induce ER stress, which eventually reduce the plasma membrane targeting of Pgp, thereby it ultimately leads to MDR reversal. 


\section{BIBLIOGRAPHY}

A.J. Darby, Richard, Richard Callaghan, and Roisin M. McMahon. 2011. "P-Glycoprotein Inhibition: The Past, the Present and the Future." Current Drug Metabolism 12 (8): 72231.

Abdal Dayem, Ahmed, Mohammed Kawser Hossain, Soo Bin Lee, Kyeongseok Kim, Subbroto Kumar Saha, Gwang-Mo Yang, Hye Yeon Choi, and Ssang-Goo Cho. 2017. "The Role of Reactive Oxygen Species (ROS) in the Biological Activities of Metallic Nanoparticles.” International Journal of Molecular Sciences 18 (1): 535796.

Abraham, Jame, Maureen Edgerly, Richard Wilson, Clara Chen, Ann Rutt, Susan Bakke, Rob Robey, et al. 2009. "A Phase I Study of the P-Glycoprotein Antagonist Tariquidar in Combination with Vinorelbine." Clinical Cancer Research 15 (10): 3574-82.

Ahamed, Maqusood, Mohamad S. AlSalhi, and M. K.J. Siddiqui. 2010. "Silver Nanoparticle Applications and Human Health." Clinica Chimica Acta 411 (23-24): 1841-48.

Ahamed, Maqusood, Michael Karns, Michael Goodson, John Rowe, Saber M. Hussain, John J. Schlager, and Yiling Hong. 2008. "DNA Damage Response to Different Surface Chemistry of Silver Nanoparticles in Mammalian Cells." Toxicology and Applied Pharmacology 233 (3): 404-10.

An, Xin, Cesar Sarmiento, Tao Tan, and Hua Zhu. 2017. "Regulation of Multidrug Resistance by MicroRNAs in Anti-Cancer Therapy." Acta Pharmaceutica Sinica B 7 (1): 38-51.

Araki, Kazutaka, and Kazuhiro Nagata. 2012. "SUP: Protein Folding and Quality Control in the ER." Cold Spring Harbor Perspectives in Biology 4 (8): a015438.

Arora, S., J. Jain, J. M. Rajwade, and K. M. Paknikar. 2009. "Interactions of Silver Nanoparticles with Primary Mouse Fibroblasts and Liver Cells." Toxicology and Applied Pharmacology 236 (3): 310-18.

Asharani, P V, M P Hande, and Suresh Valiyaveettil. 2009. "Anti-Proliferative Activity of Silver Nanoparticles." BMC Cell Biology 10: 65.

Asharani, Pv, Swaminathan Sethu, Hui Kheng Lim, Ganapathy Balaji, Suresh Valiyaveettil, and M Prakash Hande. 2012. "Differential Regulation of Intracellular Factors Mediating Cell Cycle, DNA Repair and Inflammation Following Exposure to Silver Nanoparticles in Human Cells." Genome Integrity 3 (1): 2.

Avalos, Alicia, Ana Isabel Haza, Diego Mateo, and Paloma Morales. 2014. "Cytotoxicity and ROS Production of Manufactured Silver Nanoparticles of Different Sizes in Hepatoma and Leukemia Cells." Journal of Applied Toxicology 34 (4): 413-23.

Baharara, Javad, Farideh Namvar, Marzieh Mousavi, Tayebe Ramezani, and Rosfarizan Mohamad. 2014. "Anti-Angiogenesis Effect of Biogenic Silver Nanoparticles Synthesized Using Saliva Officinalis on Chick Chorioalantoic Membrane (CAM)." Molecules 19 (9): 13498-508.

Bao, Lili, Sidhartha Hazari, Smriti Mehra, Deepak Kaushal, Krzysztof Moroz, and Srikanta Dash. 2012. "Increased Expression of P-Glycoprotein and Doxorubicin Chemoresistance of Metastatic Breast Cancer Is Regulated by MiR-298." The American Journal of Pathology 180 (6): 2490-2503. 
Bates, Susan Elaine, Manuel Alvarez, Antonio Tito Fojo, and Steven Joseph Currier. 1992. "Modulation of P-Glycoprotein Phosphorylation and Drug Transport by Sodium Butyrate." Biochemistry 31 (28): 6366-72.

Bélteky, Péter, Andrea Rónavári, Nóra Igaz, Bettina Szerencsés, Ildikó Y Tóth, Ilona Pfeiffer, Mónika Kiricsi, and Zoltán Kónya. 2019. "Silver Nanoparticles: Aggregation Behavior in Biorelevant Conditions and Its Impact on Biological Activity." International Journal of Nanomedicine 14 (January): 667-87.

Biedler, June L., and Hansjörg Riehm. 1970. "Cellular Resistance to Actinomycin D in Chinese Hamster Cells in Vitro: Cross-Resistance, Radioautographic, and Cytogenetic Studies." Cancer Research 30 (4): 1174-84.

Cai, Jiyang, Jie Yang, and Dean P. Jones. 1998. "Mitochondrial Control of Apoptosis: The Role of Cytochrome C." Biochimica et Biophysica Acta - Bioenergetics 1366 (1-2): 13949.

Callaghan, Richard, Frederick Luk, and Mary Bebawy. 2014. "Inhibition of the Multidrug Resistance P-Glycoprotein: Time for a Change of Strategy?" Drug Metabolism and Disposition 42 (4): 623-31.

Cambón, A., A. Rey-Rico, S. Barbosa, J. F.A. Soltero, S. G. Yeates, J. Brea, M. I. Loza, et al. 2013. "Poly(Styrene Oxide)-Poly(Ethylene Oxide) Block Copolymers: From 'Classical' Chemotherapeutic Nanocarriers to Active Cell-Response Inducers." Journal of Controlled Release 167 (1): 68-75.

Cambón, A., A. Rey-Rico, D. Mistry, J. Brea, M. I. Loza, D. Attwood, S. Barbosa, et al. 2013. "Doxorubicin-Loaded Micelles of Reverse Poly(Butylene Oxide)-Poly(Ethylene Oxide)Poly(Butylene Oxide) Block Copolymers as Efficient 'Active' Chemotherapeutic Agents.” International Journal of Pharmaceutics 445 (1-2): 47-57.

Cano-Gauci, Danielle F., and John R. Riorda. 1987. "Action of Calcium Antagonists on Multidrug Resistant Cells. Specific Cytotoxicity Independent of Increased Cancer Drug Accumulation." Biochemical Pharmacology 36 (13): 2115-23.

Cao, Stewart Siyan, and Randal J. Kaufman. 2014. "Endoplasmic Reticulum Stress and Oxidative Stress in Cell Fate Decision and Human Disease." Antioxidants and Redox Signaling 21 (3):396-413.

Carlson, C., S. M. Hussein, A. M. Schrand, L. K. Braydich-Stolle, K. L. Hess, R. L. Jones, and J. J. Schlager. 2008. "Unique Cellular Interaction of Silver Nanoparticles: Size-Dependent Generation of Reactive Oxygen Species." Journal of Physical Chemistry B 112 (43): 13608-19.

Chae, Yun Ju, Chi Hoa Pham, Jinwon Lee, Eunjoo Bae, Jongheop Yi, and Man Bock Gu. 2009. "Evaluation of the Toxic Impact of Silver Nanoparticles on Japanese Medaka (Oryzias Latipes)." Aquatic Toxicology 94 (4): 320-27.

Chambers, T C, B Zheng, and J F Kuo. 1992. "Regulation by Phorbol Ester and Protein Kinase C Inhibitors, and by a Protein Phosphatase Inhibitor (Okadaic Acid), of P-Glycoprotein Phosphorylation and Relationship to Drug Accumulation in Multidrug-Resistant Human KB Cells." Molecular Pharmacology 41 (6): 1008-15.

Chambers, Timothy C, Jan Pohln, Robert L Raynor\$, and J F Kuo. 1993. "Identification of SDecific Sites in Human P-Glycoprotein Phosphorylated by Protein Kinase C." The 
Journal Of Biological Chemistry 268 (7): 4592-95.

Chaudhary, Preet M, and B Roninson. 1991. "Expression and Activity of P-Glycoprotein, a Multidrug Efflux Pump, in Human Hematopoietic Stem C\&Is.” Cell 66 (1): 85-94.

"Chemotherapeutic Agents - Knowledge for Medical Students and Physicians." Accessed November 17, 2020. https://www.amboss.com/us/knowledge/Chemotherapeutic_agents.

Cho, Kwangjae, Xu Wang, Shuming Nie, Zhuo Chen, and Dong M. Shin. 2008. "Therapeutic Nanoparticles for Drug Delivery in Cancer." Clinical Cancer Research 14: 1310-16.

Cho, Young Man, Yasuko Mizuta, Jun Ichi Akagi, Takeshi Toyoda, Mizuki Sone, and Kumiko Ogawa. 2018. "Size-Dependent Acute Toxicity of Silver Nanoparticles in Mice." Journal of Toxicologic Pathology 31 (1): 73-80.

Choi, Ji Eun, Soohee Kim, Jin Hee Ahn, Pilju Youn, Jin Seok Kang, Kwangsik Park, Jongheop Yi, and Doug Young Ryu. 2010. "Induction of Oxidative Stress and Apoptosis by Silver Nanoparticles in the Liver of Adult Zebrafish." Aquatic Toxicology 100 (2): 151-59.

Choi, K H, C J Chen, M Kriegler, and I B Roninson. 1988. "An Altered Pattern of CrossResistance in Multidrug-Resistant Human Cells Results from Spontaneous Mutations in the Mdr1 (P-Glycoprotein) Gene." Cell 53 (4): 519-29.

Christen, Verena, Martinus Capelle, and Karl Fent. 2013. "Silver Nanoparticles Induce Endoplasmatic Reticulum Stress Response in Zebrafish." Toxicology and Applied Pharmacology 272 (2): 519-28.

Chung, Francisco S, Jayson S Santiago, Miguel Francisco, M De Jesus, Camille V Trinidad, Melvin Floyd, and E See. 2016. "Disrupting P-Glycoprotein Function in Clinical Settings: What Can We Learn from the Fundamental Aspects of This Transporter?" Am J Cancer Res 6 (8):1583-98.

Conklin, Kenneth A. 2004. "Chemotherapy-Associated Oxidative Stress: Impact on Chemotherapeutic Effectiveness." Integrative Cancer Therapies 3 (4): 294-300.

Cooper, Robert J., and Nadja Spitzer. 2015. "Silver Nanoparticles at Sublethal Concentrations Disrupt Cytoskeleton and Neurite Dynamics in Cultured Adult Neural Stem Cells." NeuroToxicology 48 (May): 231-38.

Cordon-Cardo, C, J P O’Brien, J Boccia, D Casals, J R Bertino, and M R Melamed. 1990. "Expression of the Multidrug Resistance Gene Product (P-Glycoprotein) in Human Normal and Tumor Tissues." Journal of Histochemistry \& Cytochemistry 38 (9): 127787.

Cortese-Krott, Miriam M., Meike Münchow, Elvis Pirev, Florian Heßner, Ahmed Bozkurt, Peter Uciechowski, Norbert Pallua, Klaus-D. Kröncke, and Christoph V. Suschek. 2009. "Silver Ions Induce Oxidative Stress and Intracellular Zinc Release in Human Skin Fibroblasts." Free Radical Biology and Medicine 47 (11): 1570-77.

Cruchten, S. Van, and W. Van den Broeck. 2002. "Morphological and Biochemical Aspects of Apoptosis, Oncosis and Necrosis." Anatomia, Histologia, Embryologia: Journal of Veterinary Medicine Series C 31 (4): 214-23.

David, A. Rosalie, and Michael R. Zimmerman. 2010. "Cancer: An Old Disease, a New Disease or Something in Between?" Nature Reviews Cancer 10 (10): 728-33. 
Eom, Hyun-Jeong, and Jinhee Choi. 2010. "P38 MAPK Activation, DNA Damage, Cell Cycle Arrest and Apoptosis As Mechanisms of Toxicity of Silver Nanoparticles in Jurkat T Cells." Environmental Science \& Technology 44 (21): 8337-42.

F. Abdulkarim, Muthanna, Charles Heard, and Raid G. Alany. 2012. "An Overview of Recent Patents on Nanoparticles for Drug Delivery Across the Blood Brain Barrier." Recent Patents on Nanomedicinee 2 (1): 45-51.

Farkas, Julia, Paul Christian, Julián Alberto Gallego-Urrea, Norbert Roos, Martin Hassellöv, Knut Erik Tollefsen, and Kevin V. Thomas. 2011. "Uptake and Effects of Manufactured Silver Nanoparticles in Rainbow Trout (Oncorhynchus Mykiss) Gill Cells." Aquatic Toxicology 101 (1): 117-25.

Folkman, Judah. 1971. "Tumor Angiogenesis: Therapeutic Implications." New England Journal of Medicine 285 (1): 1182-86.

Forster, Samantha, Alfred E. Thumser, Steve R. Hood, and Nick Plant. 2012. "Characterization of Rhodamine-123 as a Tracer Dye for Use In In Vitro Drug Transport Assays." PLoS ONE 7 (3): e33253.

Franco, Rodrigo, Roberto Sánchez-Olea, Elsa M. Reyes-Reyes, and Mihalis I. Panayiotidis. 2009. "Environmental Toxicity, Oxidative Stress and Apoptosis: Ménage à Trois." Mutation Research - Genetic Toxicology and Environmental Mutagenesis 674 (1-2): 322.

Gazit, G, J Lu, and A S Lee. 1999. "De-Regulation of GRP Stress Protein Expression in Human Breast Cancer Cell Lines." Breast Cancer Research and Treatment 54 (2): 135-46.

Gonzalez-Angulo, Ana Maria, Flavia Morales-Vasquez, and Gabriel N Hortobagyi. 2007. "Overview of Resistance to Systemic Therapy in Patients with Breast Cancer." Advances in Experimental Medicine and Biology 608: 1-22.

Gottesman, Michael M., and Ira Pastan. 1993. "Biochemistry of Multidrug Resistance Mediated by the Multidrug Transporter." Annual Review of Biochemistry 62 (1): 385-427.

Gottesman, Michael M, and Ira H Pastan. 2015. "The Role of Multidrug Resistance Efflux Pumps in Cancer: Revisiting a JNCI Publication Exploring Expression of the MDR1 (PGlycoprotein) Gene." Journal of the National Cancer Institute 107 (9): djv222.

Griffitt, Robert J, Kelly Hyndman, Nancy D Denslow, and Davis S Barber. 2009. "Comparison of Molecular and Histological Changes in Zebrafish Gills Exposed to Metallic Nanoparticles." Toxicological Sciences 107 (2): 404-15.

Guo, Dawei, Junren Zhang, Zhihai Huang, Shanxiang Jiang, and Ning Gu. 2015. "Colloidal Silver Nanoparticles Improve Anti-Leukemic Drug Efficacy via Amplification of Oxidative Stress." Colloids and Surfaces B: Biointerfaces 126: 198-203.

Gupta, Radhey S. 1985. "Cross-Resistance of Vinblastine- and Taxol-Resistant Mutants of Chinese Hamster Ovary Cells to Other Anticancer Drugs." Cancer Treatment Reports 69 (5): 515-21.

Gurunathan, Sangiliyandi, Kyung Jin Lee, Kalimuthu Kalishwaralal, Sardarpasha Sheikpranbabu, Ramanathan Vaidyanathan, and Soo Hyun Eom. 2009. "Antiangiogenic Properties of Silver Nanoparticles." Biomaterials 30 (31): 6341-50.

Haase, Andrea, Heinrich F. Arlinghaus, Jutta Tentschert, Harald Jungnickel, Philipp Graf, 
Alexandre Mantion, Felix Draude, et al. 2011. "Application of Laser Postionization Secondary Neutral Mass Spectrometry/Time-of-Flight Secondary Ion Mass Spectrometry in Nanotoxicology: Visualization of Nanosilver in Human Macrophages and Cellular Responses." ACS Nano 5 (4): 3059-68.

He, C, and D J Klionsky. 2009. "Regulation Mechanisms and Signalling Pathways of Autophagy." Annual Review of Genetics 43 (68): 67.

Helvoort, A van, A J Smith, H Sprong, I Fritzsche, A H Schinkel, P Borst, and G van Meer. 1996. "MDR1 P-Glycoprotein Is a Lipid Translocase of Broad Specificity, While MDR3 P-Glycoprotein Specifically Translocates Phosphatidylcholine." Cell 87 (3): 507-17.

Henrique, Rui, Ana I. Oliveira, Vera L. Costa, Tiago Baptista, Ana T. Martins, António Morais, Jorge Oliveira, and Carmen Jerónimo. 2013. "Epigenetic Regulation of MDR1 Gene through Post-Translational Histone Modifications in Prostate Cancer." BMC Genomics 14 (1): 898 .

Higgins, Christopher F., and Michael M. Gottesman. 1992. "Is the Multidrug Transporter a Flippase?" Trends in Biochemical Sciences 17 (1): 18-21.

Hohmann, Tim, Faramarz Dehghani, Tim Hohmann, and Faramarz Dehghani. 2019. "The Cytoskeleton-A Complex Interacting Meshwork." Cells 8 (4): 362.

Holohan, Caitriona, Sandra Van Schaeybroeck, Daniel B. Longley, and Patrick G. Johnston. 2013. "Cancer Drug Resistance: An Evolving Paradigm." Nature Reviews Cancer 13: 714-26.

Hua, Mu Yi, Hung Wei Yang, Hao Li Liu, Rung Ywan Tsai, See Tong Pang, Kun Lung Chuang, $\mathrm{Yu}$ Sun Chang, et al. 2011. "Superhigh-Magnetization Nanocarrier as a Doxorubicin Delivery Platform for Magnetic Targeting Therapy.” Biomaterials 32 (34): 8999-9010.

Jänicke, Reiner U. 2009. "MCF-7 Breast Carcinoma Cells Do Not Express Caspase-3." Breast Cancer Research and Treatment 117: 219-21.

Jeyaraj, M., G. Sathishkumar, G. Sivanandhan, D. MubarakAli, M. Rajesh, R. Arun, G. Kapildev, et al. 2013. "Biogenic Silver Nanoparticles for Cancer Treatment: An Experimental Report." Colloids and Surfaces B: Biointerfaces 106: 86-92.

Kalishwaralal, Kalimuthu, Elayappan Banumathi, SureshBabu Ram Kumar Pandian, Venkataraman Deepak, Jeyaraj Muniyandi, Soo Hyun Eom, and Sangiliyandi Gurunathan. 2009. "Silver Nanoparticles Inhibit VEGF Induced Cell Proliferation and Migration in Bovine Retinal Endothelial Cells." Colloids and Surfaces. B, Biointerfaces 73 (1): 51-57.

Kamp, Dietrun, and Cees W.m. Haest. 1998. "Evidence for a Role of the Multidrug Resistance Protein (MRP) in the Outward Translocation of NBD-Phospholipids in the Erythrocyte Membrane." Biochimica et Biophysica Acta - Biomembranes 1372 (1): 91-101.

Kanagasabai, Ragu, Karthikeyan Krishnamurthy, Lawrence J. Druhan, and Govindasamy Ilangovan. 2011. "Forced Expression of Heat Shock Protein 27 (Hsp27) Reverses PGlycoprotein (ABCB1)-Mediated Drug Efflux and MDR1 Gene Expression in Adriamycin-Resistant Human Breast Cancer Cells." Journal of Biological Chemistry 286 (38): 33289-300.

Kang, Yiyuan, Jia Liu, Bin Song, Xiaoli Feng, Lingling Ou, Limin Wei, Xuan Lai, and 
Longquan Shao. 2016. "Potential Links between Cytoskeletal Disturbances and Electroneurophysiological Dysfunctions Induced in the Central Nervous System by Inorganic Nanoparticles." Cellular Physiology and Biochemistry 40 (6): 1487-1505.

Kars, Meltem Demirel, Özlem Darcansoy Işeri, Ufuk Gündüz, Ali Uğur Ural, Fikret Arpaci, and József Molnár. 2006. "Development of Rational in Vitro Models for Drug Resistance in Breast Cancer and Modulation of MDR by Selected Compounds." Anticancer Research 26 (6 B): 4559-68.

Katayama, Kazuhiro, Kohji Noguchi, and Yoshikazu Sugimoto. 2014. " Regulations of PGlycoprotein/ABCB1/ MDR1 in Human Cancer Cells ." New Journal of Science 2014: $1-10$.

Kawata, Koji, Masato Osawa, and Satoshi Okabe. 2009. "In Vitro Toxicity of Silver Nanoparticles at Noncytotoxic Doses to HepG2 Human Hepatoma Cells." Environmental Science and Technology 43 (15): 6046-51.

Khandia, Rekha, Ashok Munjal, R. S. Bangrey, Reena Mehra, Kuldeep Dhama, and N. C. Sharma. 2015. Advances in Animal and Veterinary Sciences. Advances in Animal and Veterinary Sciences 3 (7): 372-76.

Kim, Soohee, Ji Eun Choi, Jinhee Choi, Kyu-Hyuck Chung, Kwangsik Park, Jongheop Yi, and Doug-Young Ryu. 2009. "Oxidative Stress-Dependent Toxicity of Silver Nanoparticles in Human Hepatoma Cells." Toxicology in Vitro 23 (6): 1076-84.

Kim, Soohee, and Doug Young Ryu. 2013. "Silver Nanoparticle-Induced Oxidative Stress, Genotoxicity and Apoptosis in Cultured Cells and Animal Tissues." Journal of Applied Toxicology 33 (2): 78-89.

Kohno, K, H Tanimura, S Sato, Y Nakayama, Y Makino, M Wada, A T Fojo, and M Kuwano. 1994. "Cellular Control of Human Multidrug Resistance 1 (Mdr-1) Gene Expression in Absence and Presence of Gene Amplification in Human Cancer Cells." The Journal of Biological Chemistry 269 (32): 20503-8.

Kovács, Dávid, Nóra Igaz, Csilla Keskeny, Péter Bélteky, Tímea Tóth, Renáta Gáspár, Dániel Madarász, et al. 2016. "Silver Nanoparticles Defeat P53-Positive and P53-Negative Osteosarcoma Cells by Triggering Mitochondrial Stress and Apoptosis." Nature Publishing Group 6: 27902.

Kovács, Dávid, Krisztina Szoke, Nóra Igaz, Gabriella Spengler, József Molnár, Tímea Tóth, Dániel Madarász, et al. 2016. "Silver Nanoparticles Modulate ABC Transporter Activity and Enhance Chemotherapy in Multidrug Resistant Cancer." Nanomedicine: Nanotechnology, Biology, and Medicine 12 (3): 601-10.

Kovalchuk, Olga, Jody Filkowski, James Meservy, Yaroslav Ilnytskyy, Volodymyr P Tryndyak, Vasyl' F Chekhun, and Igor P Pogribny. 2008. "Involvement of MicroRNA451 in Resistance of the MCF-7 Breast Cancer Cells to Chemotherapeutic Drug Doxorubicin." Molecula Cancer Therapy 7 (7): 2152-59.

Kowaltowski, Alicia J., Roger F. Castilho, and Anibal E. Vercesi. 2001. "Mitochondrial Permeability Transition and Oxidative Stress." FEBS Letters 495 (1-2): 12-15.

Labrie, Philippe, Shawn P. Maddaford, Jacques Lacroix, Concettina Catalano, David K.H. Lee, Suman Rakhit, and René C. Gaudreault. 2007. "In Vitro Activity of Novel Dual Action MDR Anthranilamide Modulators with Inhibitory Activity on CYP-450 (Part 2)." 
Bioorganic and Medicinal Chemistry 15 (11): 3854-68.

Laurent, Sophie, Delphine Forge, Marc Port, Alain Roch, Caroline Robic, Luce Vander Elst, and Robert N. Muller. 2008. "Magnetic Iron Oxide Nanoparticles: Synthesis, Stabilization, Vectorization, Physicochemical Characterizations, and Biological Applications." Chemical Reviews 108 (6): 2064-2110.

Lee, Eun Seong, Kun Na, and You Han Bae. 2005. "Doxorubicin Loaded PH-Sensitive Polymeric Micelles for Reversal of Resistant MCF-7 Tumor." Journal of Controlled Release 103 (2): 405-18.

Lee, Eva Y.H.P., and William J. Muller. 2010. "Oncogenes and Tumor Suppressor Genes." Cold Spring Harbor Perspectives in Biology 2 (10): a3236.

Levine, Arthur S., Luxi Sun, Rong Tan, Ying Gao, Lu Yang, Hao Chen, Yaqun Teng, and Li Lan. 2017. "The Oxidative DNA Damage Response: A Review of Research Undertaken with Tsinghua and Xiangya Students at the University of Pittsburgh." Science China Life Sciences 60 (10): 1077-80.

Liang, Y, C Yan, and N F Schor. 2001. "Apoptosis in the Absence of Caspase 3." Oncogene 20 (45): 6570-78.

Lim, Hui Kheng, P. V. Asharani, and M. Prakash Hande. 2012. "Enhanced Genotoxicity of Silver Nanoparticles in DNA Repair Deficient Mammalian Cells." Frontiers in Genetics 3 (JUN): 1-13.

Limbach, Ludwig K., Peter Wick, Pius Manser, Robert N. Grass, Arie Bruinink, and Wendelin J. Stark. 2007. "Exposure of Engineered Nanoparticles to Human Lung Epithelial Cells: Influence of Chemical Composition and Catalytic Activity on Oxidative Stress." Environmental Science and Technology 41 (11): 4158-63.

Liou, Geou-Yarh, and Peter Storz. 2010. "Reactive Oxygen Species in Cancer." Free Radical Research 44 (5): 479-96.

Liu, Jinhua, Yongxing Zhao, Qianqian Guo, Zhao Wang, Huiyuan Wang, Yongxin Yang, and Yongzhuo Huang. 2012. "TAT-Modified Nanosilver for Combating Multidrug-Resistant Cancer." Biomaterials 33 (26): 6155-61.

Lubick, Naomi. 2008. 'Nanosilver Toxicity: Ions, Nanoparticles - Or Both?” Environmental Science and Technology 42(23):8617.

Luker, Gary D., Kent R. Nilsson, Douglas F. Covey, and David Piwnica-Worms. 1999. "Multidrug Resistance ( MDR1) P-Glycoprotein Enhances Esterification of Plasma Membrane Cholesterol." Journal of Biological Chemistry 274 (11): 6979-91.

Luqmani, Y. A. 2005. "Mechanisms of Drug Resistance in Cancer Chemotherapy." Medical Principles and Practice 14 (SUPPL. 1): 35-48.

Ma, Wanrui, Li Jing, Alexandra Valladares, Suresh L Mehta, Zhizhong Wang, P Andy Li, and John J Bang. 2015. "Silver Nanoparticle Exposure Induced Mitochondrial Stress, Caspase-3 Activation and Cell Death: Amelioration by Sodium Selenite." International Journal of Biological Sciences 11 (8): 860-67.

Mao, Bin-Hsu, Jui-Chen Tsai, Chun-Wan Chen, Shian-Jang Yan, and Ying-Jan Wang. 2016. "Mechanisms of Silver Nanoparticle-Induced Toxicity and Important Role of Autophagy." Nanotoxicology 10 (8): 1021-40. 
Maria de Souza Antunes, Adelaide, Maria Simone de Menezes Alencar, Cicera Henrique da Silva, Jeziel Nunes, and Flavia Maria Lins Mendes. 2011. "Trends in Nanotechnology Patents Applied to the Health Sector." Recent Patents on Nanotechnology 6 (1): 29-43.

Mata Balaguer, Trinidad, Angeles Gómez-Martínez, Pilar García-Morales, Javier Lacueva, Rafael Calpena, Lourdes Rocamora Reverte, Natividad Lopez Riquelme, Isabel MartinezLacaci, José A Ferragut, and Miguel Saceda. 2012. "Dual Regulation of P-Glycoprotein Expression by Trichostatin A in Cancer Cell Lines." BMC Molecular Biology 13: 35.

McNeil, Scott E. 2009. "Nanoparticle Therapeutics: A Personal Perspective." Wiley Interdisciplinary Reviews: Nanomedicine and Nanobiotechnology 1 (3): 264-71.

Miethling-Graff, Rona, Rita Rumpker, Madeleine Richter, Thiago Verano-Braga, Frank Kjeldsen, Jonathan Brewer, James Hoyland, Horst Günter Rubahn, and Helmut Erdmann. 2014. "Exposure to Silver Nanoparticles Induces Size- and Dose-Dependent Oxidative Stress and Cytotoxicity in Human Colon Carcinoma Cells." Toxicology in Vitro 28 (7): 1280-89.

Milane, Lara, Zhenfeng Duan, and Mansoor Amiji. 2011. "Therapeutic Efficacy and Safety of Paclitaxel/Lonidamine Loaded EGFR-Targeted Nanoparticles for the Treatment of MultiDrug Resistant Cancer.” PLoS ONE 6 (9): 0024075.

Miura, Nobuhiko, and Yasushi Shinohara. 2009. "Cytotoxic Effect and Apoptosis Induction by Silver Nanoparticles in HeLa Cells." Biochemical and Biophysical Research Communications 390 (3): 733-37.

Molinari, Agnese, Annarica Calcabrini, Stefania Meschini, Annarita Stringaro, Donatella Del Bufalo, Maurizio Cianfriglia, and Giuseppe Arancia. 1998. "Detection of P-Glycoprotein in the Golgi Apparatus of Drug-Untreated Human Melanoma Cells." International Journal of Cancer 75 (6): 885-93.

Molnar, J, H Engi, N Gyemant, Z Schelz, G Spengler, I Ocsovski, M Szucs, et al. 2008. "Multidrug Resistance Reversal on Cancer Cells by Selected Carotenoids, Flavonoids and Anthocyanins." Bioactive Heterocycles Vi 15 (April): 133-59.

Mousa, S.A. 1998. "Mechanisms of Angiogenesis in Vascular Disorders: Potential Therapeutic Targets." Drugs of the Future 23 (1): 51.

Muthukkaruppan, V, L Kubai, and R Auerbach. 1982. "Tumor-Induced Neovascularization in the Mouse Eye." Journal of the National Cancer Institute 69 (3): 699-708.

Nishanth, Reddy P., Radhika G. Jyotsna, John J. Schlager, Saber M. Hussain, and Pallu Reddanna. 2011. "Inflammatory Responses of RAW 264.7 Macrophages upon Exposure to Nanoparticles: Role of ROS-NFkB Signaling Pathway." Nanotoxicology 5 (4): 50216.

Nowack, Bernd, Harald F. Krug, and Murray Height. 2011. "120 Years of Nanosilver History: Implications for Policy Makers.” Environmental Science and Technology 45 (4): 117783.

Orr, George A., Edward EL-H HanSB, Paul C Browne-, Edward Nieved, Brigid M O, ChiaPing Huang Yangl, and Susan Band Horwitzl. 1993. "Identification of the Major Phosphorylation Domain of Murine Rndrlb P-Glycoprotein Analysis Of The Protein Kinase A And Protein Kinase C Phosphorylation Sites." The Journal of Biological Chemistry 268 (33): 25054-62. 
Ott, Martin, John D Robertson, Vladimir Gogvadze, Boris Zhivotovsky, and Sten Orrenius. 2002. "Cytochrome c Release from Mitochondria Proceeds by a Two-Step Process." Proceedings of the National Academy of Sciences of the United States of America 99 (3): 1259-63.

Oyadomari, S., and M. Mori. 2004. "Roles of CHOP/GADD153 in Endoplasmic Reticulum Stress." Cell Death and Differentiation 11 (4): 381-89.

Ozols, R. F., R. E. Cunnion, R. W. Klecker, T. C. Hamilton, Y. Ostchega, J. E. Parrillo, and R. C. Young. 1987. "Verapamil and Adriamycin in the Treatment of Drug-Resistant Ovarian Cancer Patients." Journal of Clinical Oncology 5 (4): 641-47.

Pan, J. 2012. "Overcoming Gleevec-resistance by blocking oncogene addiction in malignant hematologic cells". Journal of Hematology \& Oncology 5 (S1): A6.

Parangi, S, M O'Reilly, G Christofori, L Holmgren, J Grosfeld, J Folkman, and D Hanahan. 1996. "Antiangiogenic Therapy of Transgenic Mice Impairs de Novo Tumor Growth." Proceedings of the National Academy of Sciences of the United States of America 93 (5): 2002-7.

Park, Eun Jung, Jongheop Yi, Younghun Kim, Kyunghee Choi, and Kwangsik Park. 2010. "Silver Nanoparticles Induce Cytotoxicity by a Trojan-Horse Type Mechanism." Toxicology in Vitro 24 (3): 872-78.

Park, Margriet V D Z, Arianne M. Neigh, Jolanda P. Vermeulen, Liset J J de la Fonteyne, Henny W. Verharen, Jacob J. Briedé, Henk van Loveren, and Wim H. de Jong. 2011. "The Effect of Particle Size on the Cytotoxicity, Inflammation, Developmental Toxicity and Genotoxicity of Silver Nanoparticles." Biomaterials 32 (36): 9810-17.

Pepin, X, L Attali, C Domrault, S Gallet, J M Metreau, Y Reault, P J Cardot, et al. 1997. “On the Use of Ion-Pair Chromatography to Elucidate Doxorubicin Release Mechanism from Polyalkylcyanoacrylate Nanoparticles at the Cellular Level." Journal of Chromatography. B, Biomedical Sciences and Applications 702 (1-2): 181-91.

Posgai, Ryan, Caitlin B. Cipolla-McCulloch, Kyle R. Murphy, Saber M. Hussain, John J. Rowe, and Mark G. Nielsen. 2011. "Differential Toxicity of Silver and Titanium Dioxide Nanoparticles on Drosophila Melanogaster Development, Reproductive Effort, and Viability: Size, Coatings and Antioxidants Matter." Chemosphere 85 (1): 34-42.

Povea-Cabello, Suleva, Manuel Oropesa-Ávila, Patricia de la Cruz-Ojeda, Marina VillanuevaPaz, Mario de la Mata, Juan Suárez-Rivero, Mónica Álvarez-Córdoba, et al. 2017. "Dynamic Reorganization of the Cytoskeleton during Apoptosis: The Two Coffins Hypothesis.” International Journal of Molecular Sciences 18 (11): 2393.

Praetorius, Natalie, and Tarun Mandal. 2008. "Engineered Nanoparticles in Cancer Therapy." Recent Patents on Drug Delivery \& Formulation 1 (1): 37-51.

Pusztai, Lajos, Peter Wagner, Nuhad Ibrahim, Edgardo Rivera, Richard Theriault, Daniel Booser, Fraser W. Symmans, et al. 2005. "Phase II Study of Tariquidar, a Selective PGlycoprotein Inhibitor, in Patients with Chemotherapy-Resistant, Advanced Breast Carcinoma." Cancer 104 (4): 682-91.

Rahman, M. F., J. Wang, T. A. Patterson, U. T. Saini, B. L. Robinson, G. D. Newport, R. C. Murdock, J. J. Schlager, S. M. Hussain, and S. F. Ali. 2009. "Expression of Genes Related 
to Oxidative Stress in the Mouse Brain after Exposure to Silver-25 Nanoparticles." Toxicology Letters 187 (1): 15-21.

Rashid, Harun Or, Raj Kumar Yadav, Hyung Ryong Kim, and Han Jung Chae. 2015. "ER Stress: Autophagy Induction, Inhibition and Selection.” Autophagy 11 (11): 1956-77.

Recordati, Camilla, Marcella De Maglie, Silvia Bianchessi, Simona Argentiere, Claudia Cella, Silvana Mattiello, Francesco Cubadda, et al. 2016. "Tissue Distribution and Acute Toxicity of Silver after Single Intravenous Administration in Mice: Nano-Specific and Size-Dependent Effects." Particle and Fibre Toxicology 13 (1): 12.

Riordan, John R., and Victor Ling. 1985. "Genetic and Biochemical Characterization of Multidrug Resistance." Pharmacology and Therapeutics 28 (1): 51-75.

Roche, Joëlle. 2018. "The Epithelial-to-Mesenchymal Transition in Cancer.” Cancers 10 (2).

Rónavári, A., N. Igaz, M.K. Gopisetty, B. Szerencsés, D. Kovács, C. Papp, C. Vágvölgyi, et al. 2018. "Biosynthesized Silver and Gold Nanoparticles Are Potent Antimycotics against Opportunistic Pathogenic Yeasts and Dermatophytes." International Journal of Nanomedicine 13: 695-703.

Roy, P., E. Reavey, M. Rayne, S. Roy, M. Abed El Baky, Y. Ishii, and C. Bartholomew. 2010. "Enhanced Sensitivity to Hydrogen Peroxide-Induced Apoptosis in Evil Transformed Rat1 Fibroblasts Due to Repression of Carbonic Anhydrase III.” FEBS Journal 277 (2): 441-52.

Ruetz, S. 1994. "Phosphatidylcholine Translocase: A Physiological Role for the Mdr2 Gene." Cell 77 (7): 1071-81.

Ruoslahti, Erkki, Sangeeta N. Bhatia, and Michael J. Sailor. 2010. "Targeting of Drugs and Nanoparticles to Tumors." Journal of Cell Biology 188 (6): 759-68.

Rutkevich, Lori A, and David B Williams. 2011. "Participation of Lectin Chaperones and Thiol Oxidoreductases in Protein Folding within the Endoplasmic Reticulum." Current Opinion in Cell Biology 23 (2): 157-66.

Rutnam, Zina Jeyapalan, Thomas N. Wight, and Burton B. Yang. 2013. "MiRNAs Regulate Expression and Function of Extracellular Matrix Molecules." Matrix Biology 32 (2): 7485.

Sadasivan, R., R. Morgan, C. Fabian, and R. Stephens. 1991. "Reversal of Multidrug Resistance in HL-60 Cells by Verapamil and Liposome-Encapsulated Doxorubicin." Cancer Letters 57 (2): 165-71.

Sahoo, Sanjeeb K., Wenxue Ma, and Vinod Labhasetwar. 2004. "Efficacy of TransferrinConjugated Paclitaxel-Loaded Nanoparticles in a Murine Model of Prostate Cancer." International Journal of Cancer 112 (2): 335-40.

Schinkel, A. H., U. Mayer, E. Wagenaar, C. A. A. M. Mol, L. van Deemter, J. J. M. Smit, M. A. van der Valk, et al. 1997. "Normal Viability and Altered Pharmacokinetics in Mice Lacking Mdr1-Type (Drug-Transporting) P-Glycoproteins." Proceedings of the National Academy of Sciences 94 (8): 4028-33.

Schirrmacher, Volker. 2019. "From Chemotherapy to Biological Therapy: A Review of Novel Concepts to Reduce the Side Effects of Systemic Cancer Treatment (Review)." International Journal of Oncology 54 (2): 407-19. 
Schluep, T., Jungyeong Hwang, Jianjun Cheng, Jeremy D Heidel, Derek W Bartlett, Beth Hollister, and Mark E Davis. 2006. "Preclinical Efficacy of the Camptothecin-Polymer Conjugate IT-101 in Multiple Cancer Models." Clinical Cancer Research 12 (5): 160614.

Senthebane, Dimakatso Alice, Arielle Rowe, Nicholas Ekow Thomford, Hendrina Shipanga, Daniella Munro, Mohammad A.M. Al Mazeedi, Hashim A.M. Almazyadi, et al. 2017. "The Role of Tumor Microenvironment in Chemoresistance: To Survive, Keep Your Enemies Closer.” International Journal of Molecular Sciences 18 (7): 1586.

Sharom, Frances Jane. 2014. "Complex Interplay between the P-Glycoprotein Multidrug Efflux Pump and the Membrane: Its Role in Modulating Protein Function." Frontiers in Oncology 4 (March): 1-19.

Shim, Ilseob, Kyunghee Choi, and Seishiro Hirano. 2017. "Oxidative Stress and Cytotoxic Effects of Silver Ion in Mouse Lung Macrophages J774.1 Cells." Journal of Applied Toxicology 37 (4): 471-78.

Simard, Jean-Christophe, Isabelle Durocher, and Denis Girard. 2016. "Silver Nanoparticles Induce Irremediable Endoplasmic Reticulum Stress Leading to Unfolded Protein Response Dependent Apoptosis in Breast Cancer Cells." Apoptosis 21 (11): 1-12.

Sinha, Tarini. 2018. "Canc Therapy \& Oncol Int J Tumors: Benign and Malignant Cancer Therapy \& Oncology International Journal.” Canc Therapy \& Oncol Int J 10 (3): 555790.

Soares, Tânia, Daniela Ribeiro, Carina Proença, Renan Campos Chisté, Eduarda Fernandes, and Marisa Freitas. 2016. "Size-Dependent Cytotoxicity of Silver Nanoparticles in Human Neutrophils Assessed by Multiple Analytical Approaches." Life Sciences 145 (January): 247-54.

Sriram, M. I., Kalishwaralal, K., Barathmanikanth, S., \& Gurunathani, S. 2012. "Size-based cytotoxicity of silver nanoparticles in bovine retinal endothelial cells". Nanoscience Methods 1 (1): 56-77.

Stępkowski, T.M., K. Brzóska, and M. Kruszewski. 2014. "Silver Nanoparticles Induced Changes in the Expression of NF-KB Related Genes Are Cell Type Specific and Related to the Basal Activity of NF-KB." Toxicology in Vitro 28 (4): 473-78.

Stierlé, Vérène, Alain Laigle, and Béatrice Jollès. 2005. "Modulation of MDR1 Gene Expression in Multidrug Resistant MCF7 Cells by Low Concentrations of Small Interfering RNAs.” Biochemical Pharmacology 70 (10): 1424-30.

Sui, H, Z-Z Fan, and Q Li. 2012. "Signal Transduction Pathways and Transcriptional Mechanisms of $A B C B 1$ /Pgp-Mediated Multiple Drug Resistance in Human Cancer Cells." Journal of International Medical Research 40 (2): 426-35.

Susa, Michiro, Arun K. Iyer, Keinosuke Ryu, Edwin Choy, Francis J. Hornicek, Henry Mankin, Lara Milane, Mansoor M. Amiji, and Zhenfeng Duan. 2010. "Inhibition of ABCB1 (MDR1) Expression by an SiRNA Nanoparticulate Delivery System to Overcome Drug Resistance in Osteosarcoma." PLoS ONE 5 (5): e10764.

Suzuki, Ryo, Tomoko Takizawa, Yasuhiro Kuwata, Mahito Mutoh, Nobuyuki Ishiguro, Naoki Utoguchi, Atsuko Shinohara, Masazumi Eriguchi, Hironobu Yanagie, and Kazuo Maruyama. 2008. "Effective Anti-Tumor Activity of Oxaliplatin Encapsulated in 
Transferrin-PEG-Liposome." International Journal of Pharmaceutics 346 (1-2): 143-50.

Thierry, Alain R., Timothy J. Jorgensen, Diana Forst, James A. Belli, Anatoly Dritschilo, and Aquilur Rahman. 2017. "Multidrug Resistance in Chinese Hamster Cells: Effect of Liposome-Encapsulated Doxorubicin." Cancer Communications 1 (5): 311-16.

Thottassery, Jaideep V, Gerard P Zambetti, Kazuhiko Arimori, Erin G Schuetz, and John D Schuetz. 1997. "P53-Dependent Regulation of MDR1 Gene Expression Causes Selective Resistance to Chemotherapeutic Agents." Pharmacology 94 (20): 11037-42.

Tomiyasu, Hirotaka, Yuko Goto-Koshino, Yasuhito Fujino, Koichi Ohno, and Hajime Tsujimoto. 2014. "Epigenetic Regulation of the ABCB1 Gene in Drug-Sensitive and Drug-Resistant Lymphoid Tumour Cell Lines Obtained from Canine Patients." The Veterinary Journal 199 (1): 103-9.

Toth, Monika, Imre M. Boros, and Eva Balint. 2012. "Elevated Level of Lysine 9-Acetylated Histone H3 at the MDR1 Promoter in Multidrug-Resistant Cells." Cancer Science 103 (4): 659-69.

Trachootham, Dunyaporn, Jerome Alexandre, and Peng Huang. 2009. “Targeting Cancer Cells by ROS-Mediated Mechanisms: A Radical Therapeutic Approach?" Nature Reviews Drug Discovery 8: 579-91.

Tran, Quang Huy, Van Quy Nguyen, and Anh-Tuan Le. 2013. "Silver Nanoparticles: Synthesis, Properties, Toxicology, Applications and Perspectives." Advances in Natural Sciences: Nanoscience and Nanotechnology 4 (3): 033001.

Traycoff, C M, A Orazi, A C Ladd, S Rice, J McMahel, and E F Srour. 1998. "ProliferationInduced Decline of Primitive Hematopoietic Progenitor Cell Activity Is Coupled with an Increase in Apoptosis of Ex Vivo Expanded CD34+ Cells." Experimental Hematology 26 (1): 53-62.

Valverde, Miguel A., Mario DÍaz, Francisco V. Sepúlveda, Deborah R. Gill, Stephen C. Hyde, and Christopher F. Higgins. 1992. "Volume-Regulated Chloride Channels Associated with the Human Multidrug-Resistance P-Glycoprotein.” Nature 355 (6363): 830-33.

Varga, Andras, Esin Aki-Sener, Ismail Yalcin, Ozlem Temiz-Arpaci, Betul Tekiner-Gulbas, Georgy Cherepnev, and Joseph Molnar. 2005. "Induction of Apoptosis and Necrosis by Resistance Modifiers Benzazoles and Benzoxazines on Tumour Cell Line Mouse Lymphoma L5718 Mdr+cells.” In Vivo 19 (6): 1087-92.

Vauthier, C., C. Dubernet, C. Chauvierre, I. Brigger, and P. Couvreur. 2003. "Drug Delivery to Resistant Tumors: The Potential of Poly(Alkyl Cyanoacrylate) Nanoparticles." In Journal of Controlled Release 93:151-60.

Veen, Hendrik W. van, Richard Callaghan, Loredana Soceneantu, Alessandro Sardini, Wil N. Konings, and Christopher F. Higgins. 1998. "A Bacterial Antibiotic-Resistance Gene That Complements the Human Multidrug-Resistance P-Glycoprotein Gene." Nature 391 (6664): 291-95.

Vilaboa, Nuria E, Alba Galá, Alfonso Troyano, Elena De Blas, and Patricio Aller. 2000. "Regulation of Multidrug Resistance 1 (MDR1)/P-Glycoprotein Gene Expression and Activity by Heat-Shock Transcription Factor 1 (HSF1)." Journal of Biological Chemistry 275 (32): 24970-76.

Volk, E L, K Rohde, M Rhee, J J McGuire, L A Doyle, D D Ross, and E Schneider. 2000. 
"Methotrexate Cross-Resistance in a Mitoxantrone-Selected Multidrug-Resistant MCF7 Breast Cancer Cell Line Is Attributable to Enhanced Energy-Dependent Drug Efflux." Cancer Research 60 (13): 3514-21.

Wan, Yu, Zhirui Guo, Xiaoli Jiang, Kun Fang, Xiang Lu, Yu Zhang, and Ning Gu. 2013. "Quasi-Spherical Silver Nanoparticles: Aqueous Synthesis and Size Control by the SeedMediated Lee-Meisel Method." Journal of Colloid and Interface Science 394 (1): 26368.

Wang, Tao, and Daniel N. Hebert. 2003. "EDEM an ER Quality Control Receptor." Nature Structural Biology 10 (5): 319-21.

Williams, D. A. 1993. "Ex Vivo Expansion of Hematopoietic Stem and Progenitor Cells Robbing Peter to Pay Paul?" Blood 81 (12): 3169-72.

Williams, D. B. 2006. "Beyond Lectins: The Calnexin/Calreticulin Chaperone System of the Endoplasmic Reticulum.” Journal of Cell Science 119: 615-23.

$\mathrm{Xu}$, Chunyan, Beatrice Bailly-Maitre, and John C Reed. 2005a. "Endoplasmic Reticulum Stress: Cell Life and Death Decisions." The Journal of Clinical Investigation 115 (10): 2656-64.

Xu, Ming, Qiuyuan Yang, Lining Xu, Ziyu Rao, Dong Cao, Ming Gao, and Sijin Liu. 2019. "Protein Target Identification and Toxicological Mechanism Investigation of Silver Nanoparticles-Induced Hepatotoxicity by Integrating Proteomic and Metallomic Strategies." Particle and Fibre Toxicology 16 (1): 1-14.

Xue, Pingping, Xiaofan Yang, Yang Liu, Chaomei Xiong, and Jinlan Ruan. 2014. "A Novel Compound RY10-4 Downregulates P-Glycoprotein Expression and Reverses MultidrugResistant Phenotype in Human Breast Cancer MCF-7/ADR Cells." Biomedicine and Pharmacotherapy 68 (8): 1049-56.

Xue, Y, J Wang, Y Huang, X Gao, L Kong, T Zhang, and M Tang. 2018. "Comparative Cytotoxicity and Apoptotic Pathways Induced by Nanosilver in Human Liver HepG2 and L02 Cells.” Human \& Experimental Toxicology 37 (12): 1293-1309.

Yamagishi, Tetsuo, Sumit Sahni, Danae M. Sharp, Akanksha Arvind, Patric J. Jansson, and Des R. Richardson. 2013. "P-Glycoprotein Mediates Drug Resistance via a Novel Mechanism Involving Lysosomal Sequestration." Journal of Biological Chemistry 288 (44): 31761-71.

Yang, Haotian, Rehan M Villani, Haolu Wang, Matthew J Simpson, Michael S Roberts, Min Tang, and Xiaowen Liang. 2018. "The Role of Cellular Reactive Oxygen Species in Cancer Chemotherapy." Journal of Experimental \& Clinical Cancer Research 37 (1): 266.

Yang, Yamin, and Hongjun Wang. 2014. "Applications of Nanomaterials for Cancer Treatment: Recent Patents Review.” Recent Patents on Nanomedicine 3 (2): 75-82.

Yu, Dale K. 1999. "The Contribution of P-Glycoprotein to Pharmacokinetic Drug-Drug Interactions." Journal of Clinical Pathology 39: 1203-11.

Zhan, Zhirong, Victor A. Sandor, Erick Gamelin, Joanna Regis, Bruce Dickstein, Wyndham Wilson, Antonio T. Fojo, and Susan E. Bates. 1997. "Expression of the Multidrug Resistance-Associated Protein Gene in Refractory Lymphoma: Quantitation by a Validated Polymerase Chain Reaction Assay.” Blood 89 (10): 3795-3800. 
Zhang, Rui, Mei Jing Piao, Ki Cheon Kim, Areum Daseul Kim, Jinhee Jeong Yun Choi, Jinhee Jeong Yun Choi, and Jin Won Hyun. 2012. "Endoplasmic Reticulum Stress Signaling Is Involved in Silver Nanoparticles-Induced Apoptosis." International Journal of Biochemistry and Cell Biology 44 (1): 224-32.

Zielinska, Ewelina, Agata Zauszkiewicz-Pawlak, Michal Wojcik, and Iwona InkielewiczStepniak. 2018. "Silver Nanoparticles of Different Sizes Induce a Mixed Type of Programmed Cell Death in Human Pancreatic Ductal Adenocarcinoma." Oncotarget 9 (4): 4675-97. 


\section{SUMMARY}

Chemotherapy is among the most effective treatment modalities in cancer management and is preferentially applied to treat several types of cancer. Despite its effectiveness chemotherapy often induces the development of drug resistance in cancer cells. Resistance to a particular compound /drug is undoubtedly easier to deal with, whereas resistance to numerous other structurally and functionally dissimilar drugs - termed multidrug resistance (MDR)- is extremely problematic. MDR cells are often unresponsive to most of the clinically utilized drugs which are usually effective in inducing cytotoxicity in a successful chemotherapy setting. Overexpression of P-glycoprotein (Pgp) is a key element in the development of MDR in cancer cells. Therefore, inhibition of Pgp activity could be the ultimate solution to improve the survival of patients and to raise the success rate of conventional chemotherapy. Despite, numerous scientific efforts to develop Pgp inhibitors, most of them proved to be either ineffective or exerted serious side effects under in vivo circumstances and were eventually dismissed on the basis of safety, efficacy and disappointing performance in clinical trials.

Silver nanoparticles (AgNPs) have been extensively studied in recent years, thus their unique physicochemical, antibacterial, antifungal and antiviral features are already characterized in details. However, at the same time these singular biological features were examined, it was also suggested that AgNPs might have a potential in cancer therapy owing to their remarkable anti-proliferative, cytotoxic and apoptosis inducing features. Exposure to AgNPs can lead to the accumulation and aggregation of misfolded proteins, activation of endoplasmic reticulum (ER) stress and unfolded protein response (UPR) in cells. Previously published reports from our lab and by others suggest that AgNPs are able to target the MDRrelated biological profile of tumor cells, namely modulate the expression and the efflux activity of Pgp, but the molecular background of the reduced transport activity and its dependence on the nanoparticle diameters remain open questions for future studies. Therefore, the main goal of our present study was to investigate whether the actual AgNP size would influence the AgNP-induced molecular mechanisms and the inhibitory actions on P-glycoprotein in multidrug-resistant breast cancer cells.

Citrate-capped silver nanoparticles of two largely different sizes ( $5 \mathrm{~nm}$ and $75 \mathrm{~nm}$ diameter) were synthetized and were applied on drug-sensitive MCF-7 and drug-resistant MCF-7/KCR breast adenocarcinoma cells. Our results indicated that the AgNP-induced cytotoxicity depended on the nanoparticle size, where smaller particles i.e. $5 \mathrm{~nm}$ AgNPs were more toxic 
than larger counterparts. AgNPs effectively eliminated MCF-7/KCR cells, but according to the expectations, these multidrug-resistant cells were less susceptible to the cytotoxic effects of both $5 \mathrm{~nm}$ and $75 \mathrm{~nm}$ AgNPs compared to MCF-7 cells. Although we did not observe changes in the Pgp protein expression upon exposing MCF-7/KCR cells to either $5 \mathrm{~nm}$ or $75 \mathrm{~nm}$ AgNPs, nevertheless, only $75 \mathrm{~nm}$ AgNPs were capable to reduce drug efflux activity of Pgp in the tested MCF-7/KCR cells. This finding indicates that inhibition of Pgp-mediated drug efflux depends on AgNP size. Then multidrug-resistant MCF-7/KCR cells were treated with $75 \mathrm{~nm}$ AgNPs and with the Pgp substrate drug doxorubicin in combination and the cytotoxic and apoptosis-inducing potency of doxorubicin was examined under such circumstances and compared with the efficiency of individual doxorubicin treatments. These experiments proved that exposing MDR cancer cells to $75 \mathrm{~nm}$ AgNPs sensitizes them for doxorubicin-induced apoptosis.

Inhibition of Pgp efflux activity by $75 \mathrm{~nm} \mathrm{AgNPs} \mathrm{could} \mathrm{be} \mathrm{the} \mathrm{result} \mathrm{of} \mathrm{mitochondrial}$ dysfunction. Thus we investigated the possibility of AgNP-induced mitochondrial damage and ROS production, which ultimately influence drug transport activity, mainly by reducing the cellular ATP levels required to drive Pgp efflux. However, our results indicated that $75 \mathrm{~nm}$ AgNPs were less potent than $5 \mathrm{~nm}$ AgNPs in triggering ROS generation and damaging mitochondria. Therefore, oxidative stress-related mitochondrial dysfunction is probably not a major reason behind the attenuated Pgp activity in $75 \mathrm{~nm}$ AgNP-treated drug-resistant MCF7/KCR cells.

Endoplasmic reticulum (ER) apart from being the most fundamental reservoir of cellular calcium ions, is also a major assembly site of secretory and integral membrane proteins. Under ER stress conditions the protein folding machinery is interrupted and the transition of calcium from the ER to the cytoplasm is observed. Pgp is also a glycoprotein and needs to attain proper folding in the ER to be targeted to the plasma membrane which is its site of action. Therefore, we hypothesized that by inducing ER stress in drug-resistant cells, $75 \mathrm{~nm} \mathrm{AgNPs} \mathrm{might} \mathrm{affect}$ the number of properly folded Pgp targeted the plasma membrane, thereby leading to decreased Pgp function. Our results showed that $75 \mathrm{~nm}$ AgNPs, but not $5 \mathrm{~nm}$ AgNPs induced ER stress in MCF-7/KCR cells which was coupled with the depletion of ER calcium levels. Furthermore, plasma membrane Pgp levels were significantly decreased, whereas cytoplasmic Pgp levels increased in MCF-7/KCR cells treated with $75 \mathrm{~nm}$ AgNPs compared to untreated control. 
Our study revealed that larger sized AgNPs are potent tools for modulating Pgp activity and sensitizing multidrug-resistant breast cancers to anticancer agents. This is a highly relevant finding as it renders AgNPs attractive candidates in rational design of therapeutically useful agents for tumor targeting. 


\section{8. ÖSSZEFOGLALÓ}

A sejtek kontrollálatlan osztódása rákot okozhat. A jóindulatú daganatok kisebb, míg a rosszindulatú daganatok kifejezetten nagy kockázatot jelentenek a gazdaszervezet számára, utóbbiak elsősorban a jelentősen megnövekedett proliferációs aktivitásuk és áttétképzési hajlamuk miatt, hiszen képesek az elsődleges keletkezési helyükről a szervezet más területeire migrálni és ott újabb daganatot kialakítani. A kemoterápia a rákos daganatok kezelésének egyik hatékony terápiás lehetősége, mely többféle tumor típus eliminálásának céljára előnyösen bevethető. Azonban a rákos sejtek gyakran rezisztencia kialakulásával reagálnak a kemoterápiás kezelésre. Noha az egyetlen hatóanyaggal szemben kialakult rezisztenciát viszonylag könnyebben át lehet hidalni, a multidrog-rezisztencia (MDR), azaz mikor a sejtek nemcsak az adott gyógyszerrel szemben, hanem más, szerkezetileg és funkcionálisan eltérő hatásmechanizmusú gyógyszerekkel szemben is egyaránt ellenállóvá válnak, súlyos akadályt jelent a kemoterápia során, mivel ezek a rezisztens rákos sejtek nem reagálnak a gyógyszer/ek által indukált toxikus hatásokra megfelelően. Az MDR kialakulását nagyon gyakran a Pglikoprotein (Pgp) pumpafehérje kórosan megemelkedett kifejeződésével hozzák összefüggésbe. Ezért belátható, hogy a Pgp müködésének gátlása nem csak megoldást jelenthet a rezisztencia leküzdésére, de nagymértékben növelheti a hagyományos kemoterápia sikerességét. Bár jelentős tudományos erőfeszítések irányultak ilyen Pgp-inhibitorok fejlesztésére, ezek mindegyike kudarcba fulladt, mert a kifejlesztett gátlószerek egyike sem volt bevethető rákos betegek kezelésére, hiszen a klinikai vizsgálatok során ezeknek a molekuláknak a teljesítménye messze elmaradt az elvártaktól.

Az utóbbi években az ezüst nanorészecskéket (AgNP) széles körben tanulmányozták, így egyedi fizikai-kémiai, antibakteriális, gombaellenes és antivirális tulajdonságaikat már részletesen jellemezték. Ugyanakkor az eredmények alapján azt is feltételezni lehetett, hogy az AgNP-k potenciálisan bevethetők lehetnek a daganatos betegségek terápiájában, elsősorban kiemelkedő antiproliferatív, citotoxikus és proapoptotikus tulajdonságaiknak köszönhetően. A sejtekben az AgNP kezelést követően felhalmozódhatnak és aggregálódhatnak a hibásan feltekeredett fehérjék, endoplazmatikus retikulum (ER) stressz és ehhez kapcsolódóan sérült fehérjeválasz (unfolded protein response, UPR) indukálódhat. A csoportunk és mások által közölt adatok alapján feltételezhető, hogy az AgNP-k képesek módosítani a tumorsejtek MDR fenotípusát, feltehetőleg úgy, hogy modulálják a Pgp expresszióját és efflux aktivitását. Viszont ennek a jelenségnek, így a csökkent transzportaktivitásnak a hátterében meghúzódó 
molekuláris mechanizmusok, valamint hogy ezek milyen módon függnek az alkalmazott nanorészecskék méretétől továbbra sem ismertek. Ezért jelen tanulmányunk fö célja annak felderítése volt, hogy az ezüst nanorészecskék mérete befolyásolja-e a rákos sejtek MDR fenotípusát meghatározó molekuláris folyamatokat és így a P-glikoproteinre kifejtett gátló hatásokat multidrog-rezisztens emlőrákos sejtekben.

Ennek a célnak az érdekében két különböző méretű ( $5 \mathrm{~nm}$ és $75 \mathrm{~nm}$ átmérőjü), nagyjából gömb alakú, citráttal bevont ezüst nanorészecskét tartalmazó kolloidot állítottunk elő és ezekkel kezeltünk gyógyszer-érzékeny MCF-7 és multidrog-rezisztens MCF-7/KCR emlő adenokarcinóma sejteket. Eredményeink azt mutatták, hogy az AgNP által kiváltott citotoxicitás függ a nanorészecskék méretétől, mivel az 5 nm-es AgNP-k mérgezőbbek voltak, mint a 75 nm-es részecskék. Az AgNP-k ugyan hatékonyan elpusztították az MCF-7/KCR sejteket, de a várakozásoknak megfelelően, ezek a sejtek sokkal ellenállóbbak voltak mind az $5 \mathrm{~nm}$, mind a $75 \mathrm{~nm}$-es AgNP citotoxikus hatásaival szemben, mint a gyógyszer-érzékeny MCF-7 sejtek. Érdekes módon nemcsak a citotoxicitás, hanem a Pgp efflux aktivitásának gátlása is függött az alkalmazott nanorészecskék méretétől, mivel az 5 nm-es részecskékkel ellentétben, a 75 nm-es AgNP-k képesek voltak csökkenteni a Pgp transzport funkcióját a multidrog-rezisztens MCF-7/KCR sejtekben, annak ellenére, hogy a Pgp fehérje mennyiségében nem történt változás a nanorészecske kezelés hatására. Bebizonyítottuk azt is, hogy a doxorubicin (mely szintén szubsztrátja a Pgp transzporternek) citotoxikus és apoptózist indukáló hatékonysága jelentősen megnő a multidrog-rezisztens MCF-7/KCR sejtekben, ha a doxorubicint 75 nm-es AgNP-kel együtt alkalmazzuk. Ez az eredmény arra utal, hogy a 75 nmes AgNP-k érzékenyítik a MDR rákos sejteket a doxorubicin által indukált apoptózisra.

A 75 nm-es AgNP kezelés gátolta a Pgp efflux aktivitását, annak ellenére, hogy a Pgp pumpa expressziója nem változott. Ezt az eredményt meglehetősen érdekesnek találtuk, ami arra késztetett minket, hogy megvizsgáljuk, vajon az AgNP kezelés kivált-e mitokondriális károsodást vagy szabadgyök termelést. Ezeknek az eseményeknek bármelyike végső soron befolyásolhatja a Pgp membrántranszporter müködését, elsősorban a sejtek ATP termelésének csökkenése révén, mivel a megfelelö ATP jelenléte elengedhetetlen a Pgp efflux aktivitásához. Eredményeink azonban azt mutatták, hogy a 75 nm-es AgNP-k kevésbé voltak képesek ROS termelést vagy mitokondriális károsodást kiváltani, mint az $5 \mathrm{~nm}$-es AgNP-k. Ezért az oxidatív stressz vagy a mitokondriális diszfunkció nem tud magyarázatot adni a 75 nm-es AgNP-kel kezelt multidrog-rezisztens MCF-7/KCR sejtek esetében tapasztalt Pgp aktivitás csökkenésére. $\mathrm{Az}$ endoplazmatikus retikulum (ER) a legfontosabb helyszíne a szekréciós és integráns 
membránfehérjék összeszerelődésének és feltekeredésének. Ha ER stressz indukálódik, az megzavarja a protein feltekeredés mechanizmusának egyensúlyát. Ezért feltételeztük, hogy a 75 nm-es AgNP-k ER stresszt váltanak ki multidrog-rezisztens sejtekben, ezáltal csökken a megfelelően feltekeredett Pgp pumpa mennyisége a plazmamembránban, ahol a transzportereknek ki kell fejteniük aktivitásukat. Eredményeink azt mutatták, hogy az $5 \mathrm{~nm}$-es AgNP-k nem, viszont a nagyobb méretü, átlagosan 75 nm-es részecskék jelentős ER stresszt indukálnak az MCF-7/KCR sejtekben, ami ráadásul az ER kalcium raktárainak kimerülésével társul. Kimutattuk azt is, hogy a plazmamembránban található Pgp mennyisége szignifikánsan csökken, viszont ezzel párhuzamosan, a citoplazmatikus Pgp szintje nőtt a 75 nm-es AgNP-kel kezelt MCF-7/KCR sejtekben a kezeletlen kontrollhoz képest.

Vizsgálataink tehát arra engednek következtetni, hogy a nagyobb méretü AgNP-k hatékonyan modulálják a MDR-ért nagymértékben felelős $\mathrm{ABC}$ transzporter, a Pgp efflux aktivitását és ezáltal képesek érzékenyíteni a multidrog-rezisztens emlőrákos sejteket a kemoterápiás hatóanyagok által kiváltott citotoxikus hatásokra. Ennek a jelenségnek a hátterében valószínűleg ER stressz és ennek folyományaként, a megfelelően feltekeredett, a funkcióját ellátni képes Pgp fehérjék sejten belüli disztribúciójának zavara állhat. Ezek alapján az ezüst nanorészecskék ígéretes eszközei lehetnek a multidrog-rezisztens rákos sejteket célzó terápiás megközelítések számára, például a hagyományos hatóanyagokkal kombinációban lehetne bevetni a megfelelő méretű nanorészecskéket. 


\section{PUBLICATIONS}

\section{Publications related to thesis}

- Gopisetty, M.K.; Kovács, D.; Igaz, N.; Rónavári, A.; Bélteky, P.; Rázga, Z.; Venglovecz, V.; Csoboz, B.; Boros, I.M.; Kónya, Z.; Kiricsi M. Endoplasmic reticulum stress: major player in size-dependent inhibition of P-glycoprotein by silver nanoparticles in multidrug-resistant breast cancer cells. J. Nanobiotechnology 2019, 17, 9 IF-6.518, D1

\section{Considerable publications for thesis submission}

- Gopisetty, M.K.; Kovács, D.; Igaz, N.; Rónavári, A.; Bélteky, P.; Rázga, Z.; Venglovecz, V.; Csoboz, B.; Boros, I.M.; Kónya, Z.; Kiricsi M. Endoplasmic reticulum stress: major player in size-dependent inhibition of P-glycoprotein by silver nanoparticles in multidrug-resistant breast cancer cells. J. Nanobiotechnology 2019, 17, 9 - IF-6.518, D1

- Gopisetty, M.K.; Adamecz, D.I.; Nagy, F.I.; Baji, Á.; Lathira, V.; Szabó, M.; Gáspár, R.; Csont, T.; Frank, É.; Kiricsi, M. Androstano-arylpyrimidines: novel small molecule inhibitors of MDR1for sensitizing multidrug-resistant breast cancer cells. Eur. J. Pharm. Sci 2020, 156 (2021), 105587 - IF-3.616, Q1

\section{Other publications}

- Papp, A.; Horváth, T.; Igaz, N.; Gopisetty, M.K.; Kiricsi, M; Berkesi, D.S.; Kozma, G.; Kónya, Z.; Wilhelm, I.; Patai, R.; Polgár, T.; Bellák, T.; Tiszlavicz, L.; Rázga, Z.; Vezér, T. Presence of titanium and toxic effects observed in rat lungs, kidneys, and central nervous system in vivo and in cultured astrocytes in vitro on exposure by titanium dioxide nanorods. Int J Nanomedicine 2020, in press $\mathbf{I F - 5 . 1 1 5 , ~ Q 1 ~}$

- Molnár, B.; Gopisetty, M.K.; Adamecz, D.I.; Kiricsi, M.; Frank, É. Multistep Synthesis and In Vitro Anticancer Evaluation of 2-Pyrazolyl-Estradiol Derivatives, Pyrazolocoumarin-Estradiol Hybrids and Analogous Compounds. Molecules. 2020, 25(18), 4039 - IF-3.267, Q1

- Abd Elhameed, H.A.H.; Ungor, D.; Igaz, N.; Gopisetty, M.K.; Kiricsi, M.; Csapó, E.; Gyurcsik, B. High Molecular Weight Poly(ethylenimine)-Based Water-Soluble 
Lipopolymer for Transfection of Cancer Cells. Macromol. Biosci. 2020, 2000040 - IF3.416, Q1

- Mótyán, G.; Baji, Á.; Marć, M.A.; Gopisetty, M.K.; Adamecz, D.I.; Kiricsi, M.; Enyedy, É.A.; Frank, É. Microwave-Assisted Synthesis, Proton Dissociation Processes, and Anticancer Evaluation of Novel D-Ring-Fused Steroidal 5-Amino-1Arylpyrazoles. Appl. Sci. 2019, 10, 229 - IF-2.474, Q1

- Mótyán, G.; Gopisetty, M.K.; Kiss-Faludy, R.E.; Kulmány, Á.; Zupkó, I.; Frank, É.; Kiricsi, M. Anti-Cancer Activity of Novel Dihydrotestosterone-Derived Ring ACondensed Pyrazoles on Androgen Non-Responsive Prostate Cancer Cell Lines. Int. J. Mol. Sci. 2019, 20, 2170 - IF-4.556, Q1

- Rónavári, A.; Igaz, N.; Gopisetty, M.K.; Szerencsés, B.; Kovács, D.; Papp, C.; Vágvölgyi, C.; Boros, I.M.; Kónya, Z.; Kiricsi, M.; Pfeiffer, I. Biosynthesized silver and gold nanoparticles are potent antimycotics against opportunistic pathogenic yeasts and dermatophytes. Int. J. Nanomedicine 2018, 13 - IF-4.471, Q1

- Baji, Á.; Kiss, T.; Wölfling, J.; Kovács, D.; Igaz, N.; Gopisetty, M.K.; Kiricsi, M.; Frank, É. Multicomponent access to androstano-arylpyrimidines under microwave conditions and evaluation of their anti-cancer activity in vitro. J. Steroid Biochem. Mol. Biol. 2017, 172, 79-88 - IF-4.561, Q1

Cumulative impact factor: 37.994

MTMT Identifier: 10053039 


\section{ACKNOWLEDGEMENT}

I take this opportunity to thank each and everyone without whom I might not be able to submit my $\mathrm{PhD}$.

I am extremely thankful to my supervisor Dr. Mónika Kiricsi. Her invaluable expertise and insightful feedback on research questions and methodology have guided me to think sharply and brought my work to higher level. I am deeply indebted to her for the highest level of help, support and encouragement she provided throughout my $\mathrm{PhD}$.

I would like to extend my sincere thanks to all my lab members especially, to Dr. Dávid Kovács and Nóra Igaz for assisting me during initial training on experimental protocols and helping me in the lab whenever necessary.

I would also like to extend my deepest gratitude to Prof. Imre Miklós Boros and Dr. László Bodai who have scientifically and financially supported me at very crucial places during my $\mathrm{PhD}$.

I gratefully acknowledge the collaboration of Prof. Zoltán Kónya and Péter Bélteky who synthesized AgNPs and assisted in their characterization, Dr. Rázga Zsolt for TEM experiments, Dr. Viktória Venglovecz for her great assistance in calcium release experiments and Dr. Bálint Csoboz for his help in plasma membrane separation experiments and Dr. Éva Frank for her collaboration in my other co-authored projects.

I am profoundly thankful to the Tempus Public foundation and the University of Szeged for providing me $\mathrm{PhD}$ fellowship and research facilities and to the funders under EFOP-3.6.116-2016-00008, GINOP-2.3.2-15-2016-00035, GINOP-2.3.2-15-2016-00038, NKP-19-4SZTE-14, ÚNKP-20-5-SZTE-655, BO/00878/19/8 research grants.

I also thank all my colleagues and staff members of the department of Biochemistry and Molecular Biology. Last but not least, I would like to thank my parents, wife and daughter for their wise counsel and sympathetic ear. 